Universidade de São Paulo

Escola Superior de agricultura "Luiz de Queiroz"

\begin{abstract}
Doenças pós-colheita em citros: potencial do Lentinula edodes, Agaricus blazei, ácido jasmônico, albedo (Citrus sinensis var. Valência) e flavedo (Citrus aurantifolia var. Tahiti) no controle e na indução de resistência
\end{abstract}

Leonardo Toffano

Dissertação apresentada para obtenção do título de Mestre em Agronomia, Área de concentração: Fitopatologia

Piracicaba 2005 
Leonardo Toffano

Engenheiro Agrônomo

Doenças pós-colheita em citros: potencial do Lentinula edodes, Agaricus blazei, ácido jasmônico, albedo (Citrus sinensis var. Valência) e flavedo (Citrus aurantifolia var. Tahiti) no controle e na indução de resistência

Orientador:

Prof. Dr. SÉRGIO FLORENTINO PASCHOLATI

Dissertação apresentada para obtenção do título de Mestre em Agronomia, Área de concentração: Fitopatologia

Piracicaba

2005 
Dados Internacionais de Catalogação na Publicação (CIP) DIVISÃO DE BIBLIOTECA E DOCUMENTAÇÃO - ESALQ/USP

\section{Toffano, Leonardo}

Doenças pós-colheita em citros: potencial de Lentinula edodes Agaricus blazei, ácido jasmônico, albedo (Citrus sinensis var. Valência) e flavedo (Citrus aurantifolia var. Tahiti) no controle e na indução de resistência / Leonardo Toffano. - - Piracicaba, 2005.

85 p. : il.

Dissertação (Mestrado) - - Escola Superior de Agricultura Luiz de Queiroz, 2005.

1. Antracnose 2. Bolor-verde-dos-citros 3. Doença de planta 4. Fruta cítrica 5. Fungo fitopatogênico 6. Mancha-preta-dos-citros 7. Pós-colheita I. Título

CDD 634.3

"Permitida a cópia total ou parcial deste documento, desde que citada a fonte - O autor" 


\begin{abstract}
À Deus
pela oportunidade da vida,

Aos meus pais Ernani e Bernadete

grandes responsáveis pela minha formação,

À minha irmã Daniela,

À querida Samira,

\section{DEDICO}

Aos meus familiares,

À todos que direta ou indiretamente contribuíram para com a realização deste trabalho,

OFEREÇO 


\section{AGRADECIMENTOS}

Ao Professor Sérgio F. Pascholati pela valiosa oportunidade fornecida, orientação, respeito e amizade com que me acolheu.

Ao Dr. Marcel Spósito (FUNDECITRUS), pelo apoio e sugestões no início do projeto.

À Dra. Sylvia Dias Guzzo, pela amizade, sugestões e apoio.

Aos Professores Dr. Ângelo Jacomino e Dr. Ricardo Kluge, pela disponibilidade das instalações do Laboratório de Fisiologia Pós-colheita.

Ao grupo Fischer, pelo apoio e disponibilidade nas pesquisas.

Aos amigos do Laboratório de Fisiologia e Bioquímica Fitopatológica: André, Leonardo Cavalcanti, Maria Cristina, Marizete, Maurício, Nívea, Odair, Danilo, Paulo, Solange e Dirceu.

Ao amigo Ivan Herman Fischer pelo apoio e auxílio durante o desenvolvimento do trabalho.

À amiga Patrícia Cia pelas sugestões e incentivos.

Aos amigos que aqui encontrei, em especial Ana Paula, Alejandro, Alexandre, Davi, Daniel, Fabrício, Franklin, Gleiber, Isolda, Rock, Sílvio, Ricardo e Renata.

Aos funcionários Jefferson, Fernanda, Silvia, Rodolfo, Heloísa, Marise, Pedro Arthuso, Edivaldo, Carmen e Sandra, pela agradável convivência e atenção durante o transcorrer do curso.

Aos demais Professores do Setor de Fitopatologia pelos conhecimentos transmitidos.

Aos Professores Marco Antônio Galli e André Luis Paradela (CREUPI Faculdade de Agronomia "Manuel Carlos Gonçalves") pela valiosa participação e iniciação na minha vida acadêmica e científica.

Meu agradecimento especial a todas as pessoas aqui omitidas que contribuíram para minha formação profissional e pessoal.

À FAPESP - Fundação de Amparo à Pesquisa do Estado de São Paulo, pelo apoio financeiro. 


\section{SUMÁRIO}

RESUMO

Página

ABSTRACT

1 INTRODUÇÃO..

2 DESENVOLVIMENTO.

2.1 Revisão de literatura.

2.1.1 Doenças pós-colheita em citros.

2.1.2 Caracterização das doenças

2.1.2.1 Mancha preta dos citros.

2.1.2.1.1 Ocorrência.

2.1.2.1.2 Sintomatologia e epidemiologia.

2.1.2.1.3 Etiologia

2.1.2.1.4 Medidas de controle.

2.1.2.2 Bolor verde dos citros.

2.1.2.2.1 Ocorrência.............................................................................. 19

2.1.2.2.2 Sintomatologia e epidemiologia....................................................... 19

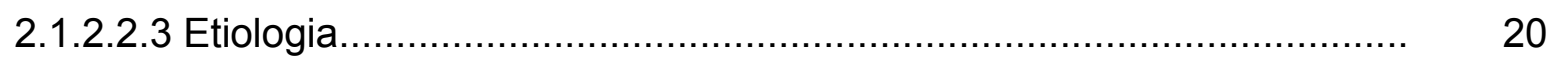

2.1.2.2.4 Medidas de controle.................................................................... 21

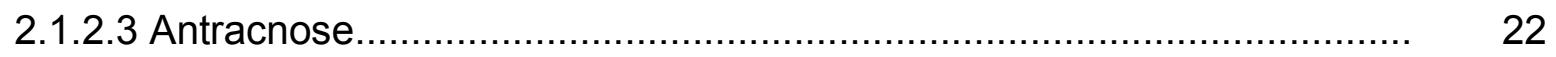

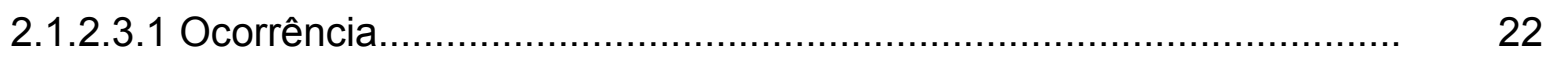

2.1.2.3.2 Sintomatologia e epidemiologia................................................... 22

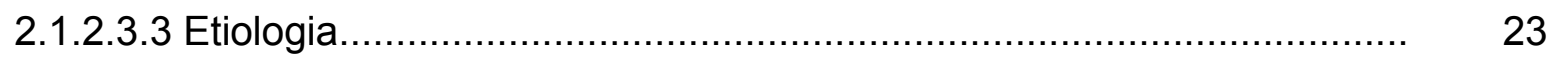

2.1.2.3.4 Medidas de controle...................................................................... 23

2.1.3 Medidas de controle pós-colheita em citros............................................ 23

2.1.4 Indução de resistência................................................................... 26

2.1.5 Agentes bióticos e abiótico de controle e indutores.................................. 27

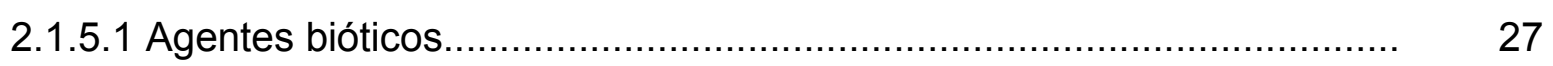

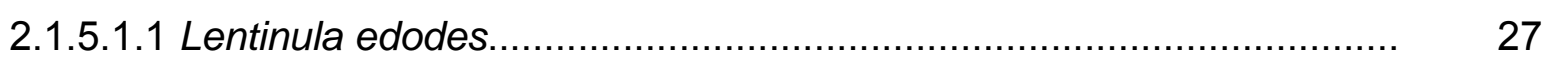

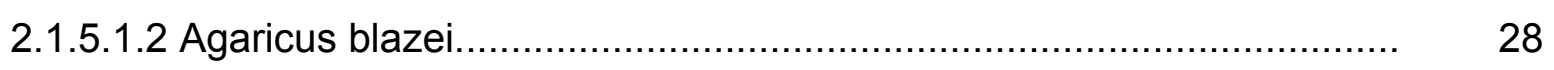


2.1.5.1.3 Albedo de Citrus sinensis var. Valência e flavedo de Citrus

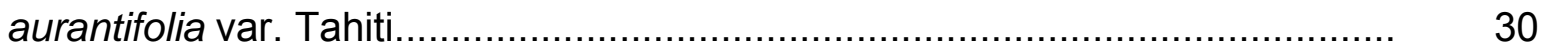

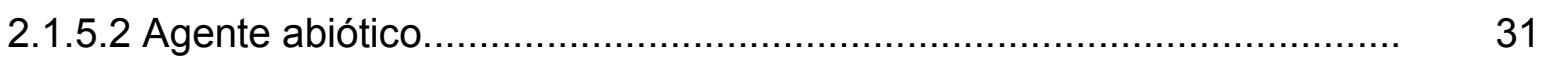

2.1.5.2.1 Ácido jasmônico.................................................................. 31

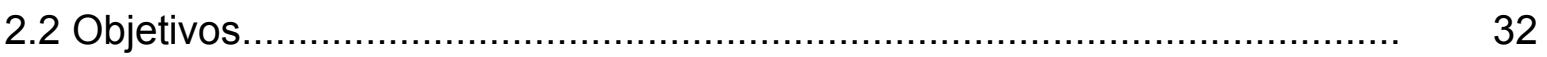

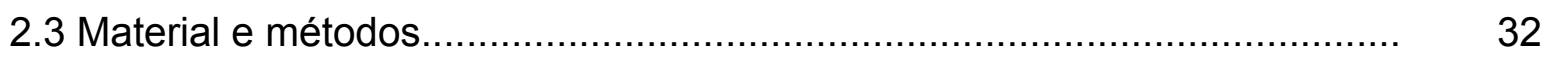

2.3.1 Influência do albedo e do flavedo no desenvolvimento in vitro de $G$.

citricarpa, P. digitatum e C. gloeosporioides................................................. 32

2.3.1.1 Obtenção e cultivo dos fitopatógenos............................................... 32

2.3.1.2 Obtenção dos materiais para os experimentos envolvendo compostos

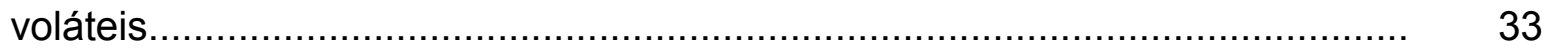

2.3.1.3 Obtenção dos extratos etanólicos e detecção da atividade antifúngica. 33

2.3.1.3.1 Influência no crescimento micelial................................................. 34

2.3.1.3.2 Influência na germinação de esporos e formação de apressório........ 34

2.3.2 Influência dos agentes bióticos e abiótico nas interações com $G$.

citricarpa, P. digitatum e C. gloeosporioides em frutos de C. sinensis var.

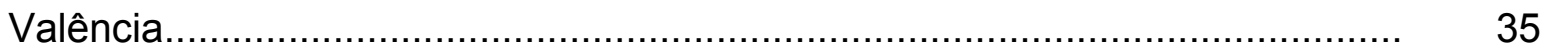

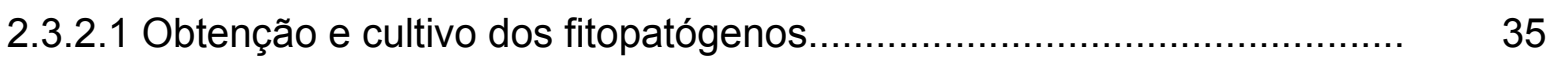

2.3.2.2 Obtenção e preparo do Lentinula edodes........................................ 35

2.3.2.3 Obtenção e preparo do Agaricus blazei............................................ 36

2.3.2.4 Obtenção e preparo do albedo e do flavedo..................................... 36

2.3.2.5 Obtenção e preparo do ácido jasmônico........................................... 36

2.3.2.6 Influência dos agentes bióticos e abiótico sobre a mancha preta dos

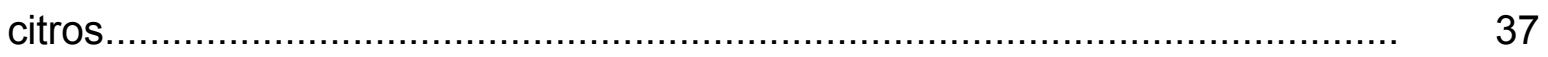

2.3.2.7 Influência dos agentes bióticos e abiótico sobre o bolor verde dos

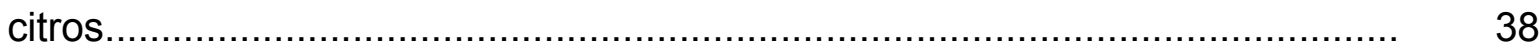

2.3.2.8 Influência dos agentes bióticos e abióticos sobre a antracnose.............. 39

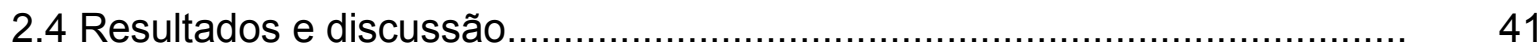

2.4.1 Influência do albedo e do flavedo no desenvolvimento in vitro de G. citricarpa, $P$. digitatum e C. gloeosporioides................................................. 41

2.4.1.1 Influência de compostos voláteis do albedo e flavedo.......................... 41 
2.4.1.2 Influência dos extratos no crescimento micelial................................... 44

2.4.1.2.1 Albedo - C. sinensis var. Valência.................................................. 44

2.4.1.2.2 Flavedo - C aurantifolia var. Tahiti............................................... 44

2.4.2 Influência dos agentes bióticos e abióticos nas interações de G.

citricarpa, P. digitatum e C. gloeosporioides com frutos de C. sinensis var.

Valência.

2.4.2.1 Influência dos agentes bióticos e abiótico sobre a mancha preta dos citros.

2.4.2.2 Influência dos agentes bióticos e abiótico sobre o bolor verde dos citros

2.4.2.2.1 Efeito "protetor"

2.4.2.2.2 Efeito "erradicante"................................................................. 57

2.4.2.2.3 Efeito "curativo" ..................................................................... 59

2.4.2.2.4 Efeito "indutor de resistência".......................................................... 62

2.4.2.3 Influência dos agentes bióticos e abiótico sobre a antracnose em frutos de laranja Valência.............................................................................. 65

2.4.2.3.1 Efeito "protetor" ..................................................................... $\quad 65$

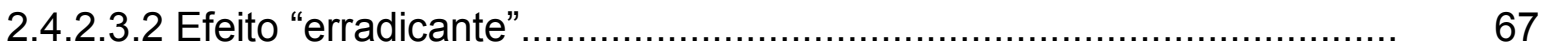

2.4.2.3.3 Efeito "curativo"....................................................................... $\quad 69$

2.4.2.3.4 Efeito "indutor de resistência".......................................................... 71

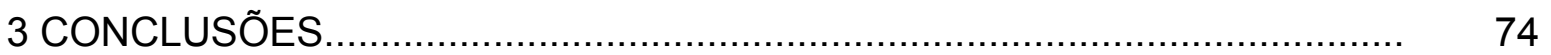

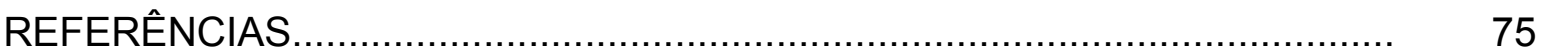




\section{RESUMO}

\section{Doenças pós-colheita em citros: potencial do Lentinula edodes, Agaricus blazei, ácido jasmônico, albedo (Citrus sinensis var. Valência) e flavedo (Citrus aurantifolia var. Tahiti) no controle e na indução de resistência.}

O Brasil é considerado o maior produtor de citros e o maior exportador de suco de laranja. Doenças de pós-colheita representam uma grande perda na citricultura, sendo que para muitos frutos a serem exportados, existe uma exigência para que os mesmos estejam isentos de resíduos químicos. Em relação a alguns patógenos de importância em pós-colheita podemos destacar, Guignardia citricarpa (Mancha-pretados-citros), Penicillium digitatum (Bolor-verde) e Colletotrichum gloeosporioides (Antracnose). Dada a importância econômica que representa esse complexo de doenças dos frutos cítricos, tanto em termos de comprometimento da qualidade dos frutos, limitações às exportações e dificuldade de controle, a busca de alternativas adicionais que possam viabilizar a capacidade produtiva dos produtores e garantir a obtenção de frutos com excelentes padrões de qualidade torna-se imprescindível. Nesse contexto, pode-se inserir o emprego de medidas de controle alternativas que não englobam o controle químico clássico. Sob esse ponto de vista inclui-se o controle através do uso de agentes bióticos e abióticos e a indução de resistência em plantas. Portanto neste trabalho, foi estudada a viabilidade do controle de doenças pós-colheita em citros, envolvendo a ação direta sobre os patógenos através do uso dos extratos etanólicos de albedo (mesocarpo) de laranja doce (Citrus sinensis var. Valência) e flavedo (exocarpo ou epicarpo) de limão-Tahiti (Citrus aurantifolia Swing var. Tahiti). O extrato do albedo apresentou efeito antifúngico sobre $G$. citricarpa e o flavedo do limão "Tahiti" sobre C. gloeosporioides, além de se demonstrar a existência de compostos voláteis com efeito tóxico. A segunda parte envolveu o controle e a indução de resistência em frutos, através do uso dos agentes bióticos Lentinula edodes e Agaricus blazei e do agente abiótico ácido jasmônico. Foi possível observar que o extrato aquoso do albedo (C. sinensis), flavedo (C. aurantifolia), L. edodes e A. blazei diminuíram o aparecimento de novas lesões causadas por G. citricarpa, porém não apresentaram efeitos sobre $P$. digitatum e $C$. gloeosporioides em frutos de $C$. sinensis var. Valência quando tratados em pós-colheita. Dessa maneira, no presente trabalho demonstrou-se a viabilidade de um possível controle alternativo de doenças pós-colheita em citros, buscando-se novos agentes que atuem como indutores de resistência ou de controle direto sobre os fitopatógenos.

Palavras-chave: Mancha preta dos citros; Bolor verde; Antracnose 


\begin{abstract}
Post-harvest citrus diseases: Potential of the Lentinula edodes, Agaricus blazei, jasmonic acid, mesocarp (Citrus sinensis var. Valência) and epicarp (Citrus aurantifolia var. Tahiti) in the control and in the resistance induction
\end{abstract}

Brazil is considered the biggest citrus producer and the biggest orange juice exporter. Post-harvest diseases represent a great loss in the citriculture, and for many fruits to be exported they should be free of chemical residues. In relation to some pathogens of importance in post-harvest it can be mentioned Guignardia citricarpa (black-spot-ofcitrus), Penicillium digitatum (green-mold) and Colletotrichum gloeosporioides (anthracnose). Because of the economical importance that represents this disease complex in citric fruits, in terms of compromising fruit quality, limitations to the exports and control difficulties, the search for alternative control measures that can make possible improve the producing capacity of the producers and the obtaining of fruits with excellent quality are indispensable. Thus, in this context it can be included measures of alternative control that do not include the chemical control. Under this point of view, control include the use of biotic and abiotic agents and the resistance induction in plants. Therefore, it was studied the viability of the control of post-harvest diseases in citrus, involving the direct action on the patogens by using ethanolic extracts of albedo (mesocarp) of sweet orange (Citrus sinensis var. Valência) and flavedo (exocarp or epicarp) of lemon-Tahiti (Citrus aurantifolia Swing var. Tahiti). The results showed that the extract of the albedo exhibited antifungal activity on G. citricarpa and the flavedo of the "Tahiti" lemon on C. gloeosporioides, and it was also demonstrated the existence of volatile compounds toxic to the fungus. The second part involved the control and resistance induction in the fruits, by using the biotic agents Lentinula edodes and Agaricus blazei and the abiotic agent jasmonic acid. It was possible to observe that the aqueous extracts from the albedo (C. sinensis), flavedo (C. aurantifolia), L. edodes and A. blazei reduced the formation of new lesions caused by G. citricarpa, however they did not exhibit effects on $P$. digitatum and $C$. gloeosporioides in fruits of $C$. sinensis var. Valência when treated in post-harvest. Thus, in the present work it was demonstrated the viability of possible alternative control measures of diseases in post-harvest of citrus, indicating the need of looking for new agents to act as resistance inducers or agents to directly control on the phytopathogens.

Keywords: Black-spot-of-citrus; Green-mold; Anthracnose 


\section{INTRODUÇÃO}

O Brasil é considerado o maior produtor de citros e o maior exportador de suco de laranja, com uma produção girando em torno de 18 milhões de toneladas, em uma área colhida de 818 mil hectares, respondendo por um terço da produção da laranja e por $47 \%$ do suco fabricado no mundo. Da produção brasileira de laranja, $71 \%$ destinase ao processamento industrial e apenas $0,6 \%$ à exportação in natura, e 28,4 \% para o consumo interno (SPÓSITO; BASSANEZI, 2002; FNP CONSULTORIA \& AGROINFORMATIVOS, 2004). Esta baixa relação entre produção e exportação devese às variedades cultivadas, mais apropriadas ao processamento e distanciadas de gostos e preferências dos consumidores de países desenvolvidos; às barreiras tarifárias e restrições sanitárias, destacando-se a exigência de qualidade pelo mercado externo, com frutas bem selecionadas, embaladas adequadamente, certificadas e sistema de rastreabilidade.

A fruta cítrica produzida no Brasil via de regra, apresenta um aspecto visual de qualidade inferior. Em relação a este fato, temos problemas com o clima, que age na coloração dos frutos e uma quantidade enorme de doenças, que levam a uma depreciação do produto final. Devido à falta de temperaturas baixas, na maioria das áreas citrícolas brasileiras, os frutos tendem a ficar com uma coloração verdolenga para um amarelo pálido, desvalorizando-os para a comercialização in natura em mercados exigentes quanto à coloração. Já os problemas fitossanitários são amplamente utilizados como barreiras não tarifárias, no intuito de restringir as importações por países, principalmente, da União Européia (UE), com objetivos protecionistas.

A UE considera como doenças quarentenárias A1 (aquelas que não estão presentes em nenhuma área dos países membros) para os frutos cítricos, a mancha preta dos citros, causada por Guignardia citricarpa Kiel. São considerados frutos com mancha preta, apenas os que apresentarem sintomas. Portanto, um trabalho adequado de escolha no packing-house faz com que nossas frutas não tenham problemas para a importação por aqueles países. Entretanto, as laranjas podem, expressar sintomas na pós-colheita, por exemplo, durante o período de transporte (ex-packing-house). Caso seja detectado apenas um fruto com um único sintoma desta doença na inspeção no porto de destino, todo o lote é rechaçado. Além desta doença, existem os bolores 
(Penicillium digitatum e P. italicum) e outras doenças típicas de pós-colheita, como a antracnose (Colletotrichum gloeosporioides), que devem ser tratadas nos packinghouses visando minimizar danos e problemas com o importador e com o consumo interno. Portanto, algumas medidas, como cuidados com os frutos durante o manuseio e transporte, devem ser tomadas para melhorar o aspecto visual dos frutos e ao mesmo tempo reduzir a possibilidade de problemas fitossanitários a partir do uso de produtos naturais, no intuito de aumentar nossas exportações e diminuir a perda de frutos para o consumo. 


\section{DESENVOLVIMENTO}

\subsection{Revisão de literatura}

\subsubsection{Doenças pós-colheita em citros}

As perdas econômicas ocasionadas por doenças de pós-colheita representam um dos principais problemas da citricultura mundial (TUSET, 1987; ECKERT; EAKS, 1989), embora estudos consistentes nas condições brasileiras sejam poucos. Em levantamento da incidência de doenças pós-colheita em frutos de laranja comercializados na Central de Abastecimento de Recife, Dantas et al. (2003) detectaram $21,9 \%$ dos frutos analisados com doenças fúngicas, com destaque para Lasiodiplodia theobromae (Pat.) Griff. \& Maubl. com 11,8\%, confirmando a importância econômica das doenças pós-colheita em frutos de laranja. A maioria dessas doenças desqualifica a fruta para comercialização, como destacado por Eckert (1993) que mencionou perdas de até $50 \%$ para laranjas, apenas durante o período de comercialização. Vários fatores relacionados com o fruto, o patógeno, o clima e as condições em pós-colheita determinam a incidência e a severidade das doenças (ECKERT; EAKS, 1989). Entre estes, a quantidade e a qualidade do inóculo fúngico ocupam um lugar de destaque. A probabilidade de infecção depende da quantidade de inóculo presente em um ponto do fruto suscetível. Esta relação foi demonstrada para patógenos como Penicillium digitatum (Pers.: Fr.) Sacc. (WILD; ECKERT, 1982), Geotrichum candidum Link: Pers. (BAUDOIN; ECKERT, 1982), e Colletotrichum gloeosporioides (Penz.) Sacc. Segundo Brown (1975), a quantidade de esporos presente nos packing-houses de citros influi nos níveis de podridão, especialmente nas provocadas por patógenos que penetram por ferimento como $P$. digitatum e $P$. italicum Wehmer, causadores, respectivamente, das podridões verde e azul, as doenças de pós-colheita de cítricos de maior impacto econômico em todo o mundo (TUSET, 1987; ECKERT; EAKS, 1989).

As infecções em pós-colheita ocorrem principalmente através de ferimentos causados durante a colheita e o posterior manejo dos frutos, podendo também se originar no campo pela ação de agentes bióticos (insetos, pássaros, etc.) ou abióticos 
(vento, chuva, granizo, etc). As infecções em pré-colheita acontecem quando o patógeno chega à flor ou ao fruto durante seu desenvolvimento no campo e permanece inativo até que em pós-colheita, as condições ambientais e fisiológicas do fruto permitam o desenvolvimento da doença (ECKERT; EAKS, 1989).

O clima, especialmente a temperatura e a umidade relativa (UR) antes e durante o período de colheita, influi na magnitude da incidência destas doenças, pois determina a quantidade de inóculo disponível, o grau de disseminação e em conseqüência, o nível da população fúngica presente nos frutos no momento da chegada ao packing-house (ECKERT; BROWN, 1986). Nas condições climáticas do mediterrâneo, caracterizadas por verões pouco chuvosos, as infecções em pós-colheita são as de maior importância econômica, destacando-se a podridão verde, causada por Penicillium digitatum e em menor intensidade as podridões azul, ácida e por Rhizopus, causadas respectivamente por P. italicum, G. candidum e R. stolonifer (Ehrenb.) Lind. (TUSET, 1987). As infecções em pré-colheita mais importantes são as podridões negra, marrom, cinza e a antracnose, causadas respectivamente por Alternaria citri Ell. \& Pierce, Phytophthora citrophthora Smith \& Smith, Botrytis cinerea Pers. ex Fr. e C. gloeosporioides (TUSET, 1987).

Em vista da grande ocorrência em quantidade, dos patógenos em frutos de laranja em pós-colheita, três patógenos foram escolhidos para os estudos.

\subsubsection{Caracterização das doenças}

\subsubsection{Mancha preta dos citros}

\subsection{Ocorrência}

A mancha preta dos frutos cítricos foi constatada pela primeira vez na Austrália, no ano de 1895, causando prejuízos elevados à produção, tanto em plantas em pomares como em frutos em pós-colheita (SUTTON; WATERSON, 1966). Foram constatados prejuízos de milhões de dólares em varias regiões produtoras de citros no mundo (CALAVAN, 1960), com perdas superiores a $80 \%$ em várias áreas de produção na Austrália e África do Sul (KLOTZ, 1978). Além destes países, sua ocorrência 
também já foi relatada em Moçambique, China, Taiwan, Indonésia, Japão, Argentina e Peru (SUTTON; WATERSON, 1966).

No Brasil, a mancha preta foi descrita, inicialmente, a partir de frutas cítricas de uma feira livre no município de Piracicaba, no Estado de São Paulo, em 1940 (AVERNA-SACCÁ, 1940), sem, no entanto, ter sido mencionada a sua importância em termos de perdas. A doença permaneceu esquecida durante vários anos, certamente devido a uma temporária redução do inóculo, resultante da epidemia da tristeza do citros, que redundou na eliminação aproximada de cerca de 11 milhões de árvores nas décadas de 30 a 40 (GÓES, 1998). Na década de 80, a doença foi relatada no Estado do Rio de Janeiro (baixada fluminense), causando perdas consideráveis em "Tangerina Rio" (ROBBS, 1990) e, atualmente, também tem ocorrido em frutos de laranjas 'Lima', 'Seleta', 'Folha Murcha', 'Natal', 'Pêra' e 'Valência' (GÓES et al.,1990). Em 1992, novas constatações do fungo foram feitas no Estado de São Paulo, causando severos prejuízos em pomares localizados na região dos municípios de Conchal e Mogi-Guaçu (GÓES; FEICHTENBERGER, 1993). Em 1986, foi encontrada no Estado do Rio Grande do Sul (Vale da Cal) causando sérios prejuízos para a citricultura daquela região (GÓES et al., 1988; GÓES et al., 1991).

\subsection{Sintomatologia e epidemiologia}

Uma característica da mancha preta é que o fungo pode estar presente em uma área por muitos anos, antes dos sintomas aparecerem. Às vezes, pode levar de 5 a 30 anos para os primeiros sintomas serem percebidos e a doença pode atingir proporções epidêmicas (KOTZÉ, 1981; 1996).

Os sintomas observados nas folhas são lesões caracterizadas pela formação de um centro acinzentado com bordos salientes marrom-escuros e um halo amarelo ao redor, parecido com os sintomas encontrados nos frutos. As lesões em folhas são, freqüentemente, encontradas em tangerinas e limoeiros verdadeiros (FUNDECITRUS, 2000).

Os primeiros sintomas aparecem no início da maturação dos frutos, o que é muito tarde para qualquer tentativa de controle (GÓES et al., 1990). Um longo período de latência (dormência ou quiescência), de seis a oito meses a depender da variedade, 
caracteriza esta doença (GÓES, 1998; WHITESIDE; GARNSEY; TIMMER, 1993). Este período termina quando o fruto amadurece, entretanto, os mecanismos envolvidos na manifestação de sintomas ainda não são compreendidos, porém podem resultar do aumento da temperatura quando o fruto está maduro ou próximo à maturidade (McONIE, 1964) e do aumento da intensidade luminosa (BRODRICK; RABIE, 1970).

A fase perfeita do fungo desenvolve-se em folhas caídas no chão, formando pseudotécios dos quais são liberados os ascósporos, considerados por Klotz (1973) os principais responsáveis pela disseminação da doença, podendo atingir plantas até 25 km de distância. Nos frutos, no interior das lesões, são observados picnídios que produzem os picnidiósporos, os quais têm sua disseminação facilitada pela água, e são os principais responsáveis pela disseminação dentro de uma mesma planta (KOTZÉ, 1981,1996). As lesões de mancha preta nos frutos normalmente são circulares, com poucos milímetros de diâmetro, e não se estendem para mais do que poucas camadas de células dentro da área do albedo (KOTZÉ, 1981, 1996; McONIE, 1967).

Os sintomas observados nos frutos (Figura 1) podem ser agrupados da seguinte forma:

- Mancha dura (Figura 1a): é o sintoma mais comum da doença, caracterizando-se por lesões deprimidas, de bordos bem definidos, com centro acinzentado, contendo frutificações (picnídios); ocorre principalmente na fase de transição do fruto verde para maduro. Em frutos verdes, as lesões apresentam um círculo amarelo ao seu redor. Frutos colhidos e infectados, embora não apresentem sintomas aparentes, podem desenvolvê-los durante o transporte ou armazenagem, não exibindo áreas deprimidas e pontuações negras;

- Mancha sardenta (Figura 1b): são lesões pequenas de coloração pardoavermelhadas, levemente deprimidas, com bordos definidos, formato irregular, normalmente sem apresentar as frutificações do fungo. Ocorrem após início da maturação dos frutos, sendo quase invisíveis a olho nu e podendo coalescer originando lesões parecidas com as formadas pela melanose. Sob condições favoráveis de temperatura e luminosidade podem dar origem à mancha virulenta;

- Falsa melanose (Figura 1c): os sintomas são semelhantes aos da melanose dos citros, diferindo pelo fato de que, ao contrário da melanose, as lesões não são ásperas. 
As lesões são pequenas, com cerca de $2 \mathrm{~mm}$, rodeadas por pontos pequenos com aproximadamente $1 \mathrm{~mm}$ de diâmetro. Este sintoma ocorre em frutos em desenvolvimento, normalmente, a partir de março-abril;

- Manchas trincadas (Figura 1d): são observadas em frutos verdes. Possui aspecto clorótico, reticulado, ligeiramente saliente e superficial, variável em tamanho, podendo apresentar halo. A aparência trincada se desenvolve à medida que o tecido lesionado envelhece. Não há formação de picnídios. Essas lesões aparecem sempre em associações com o ácaro da falsa ferrugem Phyllocoptruta oleivora;

- Mancha virulenta: caracteriza-se pela formação de lesões grandes, escuras ou de coloração marrom, deprimidas, com ou sem frutificações, de formato irregular, podendo ocupar áreas de vários centímetros quadrados, sendo deprimidas ou não. O centro possui cor cinza a as bordas são salientes, marrom escura ou vermelha escura, com ou sem frutificações. Pode ser resultante da evolução das manchas pretas e aparecem, em geral, no final da safra, quando os frutos estão maduros, e com ocorrência de altas temperaturas;

- Manchas rendilhadas, são lesões superficiais, de bordos bem definidos, coloração alaranjada com o centro amarelo-marrom a marrom-escuro, podem tomar grandes áreas da superfície do fruto, não apresentam corpos de frutificação do fungo, e em geral ocorrem em frutos verdes.

A mancha preta dos citros pode originar-se de ascósporos e de picnidiósporos, sendo que nas epidemias, a importância dos ascósporos é bem maior. Os picnidiósporos podem ocorrer em lesões de frutos, em ramos finos e secos, e em folhas caídas no solo. Ocasionalmente, também nos pedúnculos e em folhas presas na árvore. Porém, a maior parte dos picnidiósporos é produzida sobre folhas de citros caídas no chão do pomar e, se presente, em frutos maduros infectados.

Os picnidiósporos não apresentam um mecanismo especial de liberação para a atmosfera, e aqueles presentes em folhas mortas sobre o chão podem atingir frutas suscetíveis apenas por respingos de gotas de chuva. Picnidiósporos se constituem em uma fonte de inóculo quando frutas temporãs ou frutos caídos tardiamente, com lesões, permanecem nas árvores depois do florescimento ou da formação dos primeiros frutos (KOTZÉ, 1981, 1996). 
Os picnídios de $P$. citricarpa podem, ocasionalmente, ser encontrados em lesões de folhas verdes, ainda presentes na árvore, e em ramos secos. Sobre folhas caídas, o picnídio normalmente amadurece e libera seus esporos gelatinosos muitas semanas antes do peritécio amadurecer sobre as mesmas folhas.

A correlação entre liberação de ascósporos e início da infecção indica que o picnídio sobre folhas caídas não desempenha papel significativo como fonte de inóculo primário (McONIE, 1964). Os ascósporos de G. citricarpa são produzidos sobre folhas caídas no chão do pomar e representam a principal fonte de inóculo depois que a doença atingiu o estágio epidêmico. Ascósporos nunca ocorrem em lesões de frutos. Estes se desenvolvem dentro de 50 a 180 dias sobre as folhas de citros caídas das árvores durante o ano. Os ascósporos maduros podem ocorrer em qualquer período do
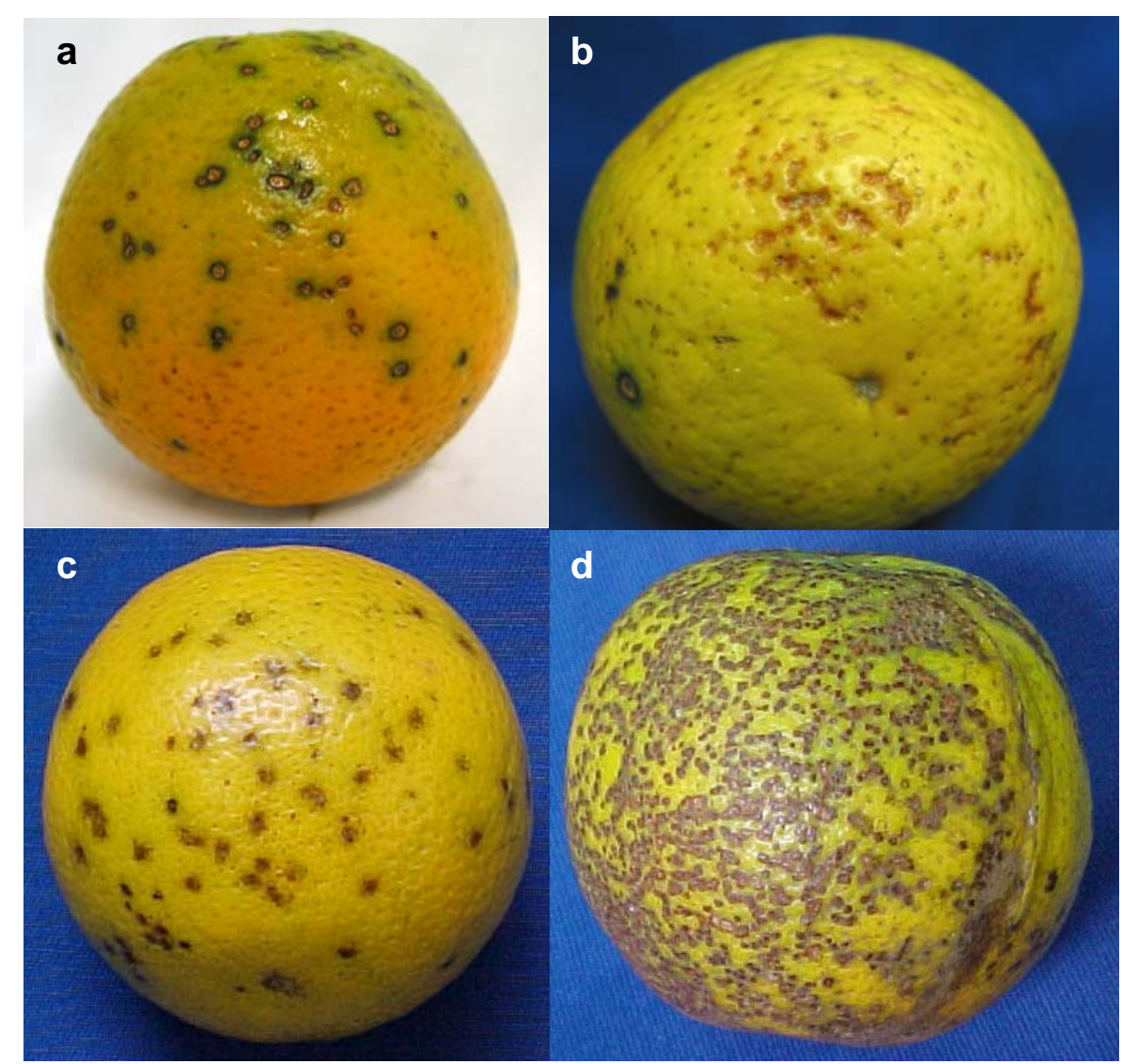

Figura 1 - Sintomas de mancha dura (a), mancha sardenta (b), falsa melanose (c) e mancha trincada (d) causadas por G. citricarpa em frutos de laranja 
ano em um pomar de citros, mas a sua presença e abundância dependem da freqüência de umidade (chuva, irrigação, etc.) e seca, bem como das temperaturas predominantes (KOTZÉ, 1981). Ainda de acordo como o mesmo autor, o período crítico de suscetibilidade dos frutos para a mancha preta ocorre desde a fase de chumbinho até cerca de seis meses após a queda das pétalas, o que corresponde, no Estado de São Paulo, ao período compreendido entre setembro a março, dependendo das variedades e condições climáticas predominantes (GÓES, 1998; GÓES et al., 1990).

\subsection{Etiologia}

O fungo causador da mancha preta dos frutos cítricos foi primeiramente descrito por McAlpine, em 1889 (McONIE, 1964) na sua forma assexuada, e recebeu a designação de Phoma citricarpa McAlpine. Posteriormente, surgiram duas novas propostas para a recombinação do binômio: Phyllosticta citricarpa (McAlpine) Petrak. e Phyllostictina citricarpa (Mc Alpine) Petrak., ambas, segundo Robbs (1990) adotadas indistintamente pelos fitopatologistas. O estágio sexual do patógeno foi descoberto por Kiely, em 1948, e foi chamado de Guignardia citricarpa Kiely (KOTZÉ, 1981, 1996). No ano de 1964, McOnie descreveu duas variantes de G. citricarpa, morfologicamente idênticas, que ocorriam em citros, sendo apenas uma delas patogênica, e a outra endofítica. Entretanto, atualmente, sabe-se que a forma endofítica é uma outra espécie denominada de Guignardia mangiferae (anamófica: Phyllosticta capitalensis), de acordo com Baayen et al. (2002). Com exceção da laranja azeda (C. aurantium L.) e seus híbridos, todas as espécies de Citrus são susceptíveis. Os limoeiros também são susceptíveis e grandes perdas podem ocorrer em laranja doce (C. sinensis) e pomelo (C. paradisi Macf.) (KOTZÉ, 1981, 1996).

\subsection{Medidas de controle}

Entre as medidas de controle estão o uso de mudas sadias, catação de frutas temporãs infectadas, controle de plantas daninhas nas linhas de plantio com herbicidas pós-emergentes antes do início da florada, irrigação no inverno, prevenindo a queda excessiva de folhas, uso de quebra-ventos, nutrição adequada da planta e boas condições de sanidade, desinfecção de veículos, materiais de colheita e equipamentos, 
e eliminação de restos de material vegetal. Associado a estes cuidados, inclui-se também o uso de fungicidas sistêmicos, a combinação de um fungicida protetor com um óleo vegetal, ou o uso de fungicida protetor isoladamente (CALAVAN, 1960; GÓES et al., 1990; KOTZÉ,1981, 1996; PRATES; NOGUEIRA, 1996). Para o caso dos pomares que produzem frutas para exportação ou para o mercado interno de frutas frescas, os produtos à base de cobre em mistura com óleo devem ser usados somente nas primeiras pulverizações. Nas demais pulverizações devem-se utilizar benzimidazóis ou estrobirulinas misturadas com óleo emulsionável.

\subsubsection{Bolor verde dos citros}

\subsection{Ocorrência}

Normalmente é a principal doença pós-colheita dos citros e está disseminada em todos os países produtores, afetando todas as espécies e cultivares cítricas. No entanto, a preocupação é maior com as variedades consumidas in natura, como as laranjas de umbigo (Bahia) e laranja Lima. Sua ocorrência depende muito das condições climáticas e da forma de manipulação dos frutos, desde o pomar até a chegada ao consumidor, podendo ocorrer tanto no armazenamento como no transporte do produto.

\subsection{Sintomatologia e epidemiologia}

O bolor verde é uma podridão mole dos frutos com posterior cobertura da lesão pelo micélio branco e por grande número de esporos verdes do fungo, que chegam a tomar todo o fruto. O primeiro estádio manifesta-se pelo surgimento de uma mancha circular mole de aspecto encharcado e pela ligeira descoloração da superfície afetada. Esta área mede aproximadamente meio centímetro e cede facilmente à pressão dos dedos. O segundo estádio compreende o aparecimento de micélio branco na superfície do fruto e o desenvolvimento, no centro do micélio, de uma massa de esporos verdes. Em temperaturas favoráveis, em menos de dois dias, a lesão alcança tamanho entre 4 e $5 \mathrm{~cm}$ de diâmetro, atingindo as vesículas de suco. Circundando a esporulação verde do patógeno, há uma faixa de micélio branco, e externamente a ela, uma região 
enrugada na casca, de consistência macia. A cor dos esporos é visível geralmente em lesões de diâmetro maior do que dois centímetros. Eles são inicialmente verde-oliva a medida que envelhecem, sendo os mesmos produzidos na superfície do fruto (LARANJEIRA et al., 2002).

Os esporos maduros soltam-se com grande facilidade a qualquer movimento ou impacto sobre os frutos afetados. Assim, são facilmente dispersos pelo manuseio, pela agitação ou exposição dos frutos a correntes de ar. Em condições de baixa umidade, os frutos murcham e mumificam. Sob condições de alta umidade, outros fungos e bactérias desenvolvem-se na lesão, e o fruto apodrece mais rapidamente. No armazenamento a granel, frutos sadios podem ser depreciados por ficarem manchados com os esporos liberados pelos frutos doentes. Frutos infectados têm seu período de armazenamento reduzido pela formação de etileno, que acelera o processo de maturação, diminuindo a vida de prateleira.

\subsection{Etiologia}

Penicillium digitatum Sacc. é o agente causal do bolor verde. O tamanho dos conídios varia de 4 a $7 \mu \mathrm{m} \times 6$ a $8 \mu \mathrm{m}$, com formato ligeiramente cilíndrico a ovalado. Eles são produzidos em cadeia, motivo pelo qual são denominados esporos catenulados, variando ligeiramente na forma e no tamanho, mesmo sendo originários do mesmo cordão de esporos. Assim como as outras espécies de Penicillium que atacam os citros $P$. digitatum produz enzimas capazes de dissolver a lamela média dos tecidos infectados de frutos, provocando podridão mole. A fase perfeita desses fungos é rara na natureza. Sobrevivem, saprofiticamente, em pomares e outros ambientes, sobre vários tipos de substratos orgânicos, na forma de conídios. As infecções originam-se de conídios carregados pelo vento que atingem a superfície dos frutos, onde penetram por ferimentos (LARANJEIRA et al., 2002).

A infecção é dependente de ferimentos e pode ocorrer em pomares, afetando frutos em fase final de maturação. Contudo, eles causam maiores prejuízos quando ocorrem após a colheita, durante as operações de processamento, armazenamento e transporte. Além dos ferimentos, a temperatura é o outro fator importante para o desenvolvimento do bolor verde. Temperaturas em torno de $24^{\circ} \mathrm{C}$ são consideradas 
ótimas e maiores que $30^{\circ} \mathrm{C}$ ou menores que $5-7{ }^{\circ} \mathrm{C}$ paralisam o crescimento do fungo. Em geral, à medida que ocorre diminuição da temperatura, o desenvolvimento do fungo é mais lento e, portanto, os sintomas são menos evidentes.

Em packing houses, devido à presença constante de frutos sadios e doentes, os ciclos de infecção e esporulação podem ocorrer repetidas vezes no período de colheita. Em contêineres, a infecção não ocorre de um fruto doente para um sadio, já que não há transmissão por contato.

\subsection{Medidas de controle}

A principal medida de controle é a colheita e o manuseio dos frutos com maior cuidado, para evitar-se ferimentos de qualquer natureza, assim como a adoção de práticas sanitárias visando eliminar frutos infectados e outras fontes de inóculo em pomares, veículos, equipamentos, materiais de colheita e transporte, e também a higienização das casas de processamento e armazenamento. O controle químico pode ser uma medida complementar.

Os esporos do patógeno são facilmente levados pelo ar e são abundantes em packing-houses, principalmente nos locais onde as caixas estão em quantidade e nos locais onde as mesmas são viradas e as frutas são limpas. Recomenda-se assim, que o processo de embalagem não ocorra nesses lugares. Um sistema de exaustão sobre esses locais leva ao exterior as nuvens de esporos que são produzidas durante tal atividade, diminuindo a densidade de inóculo.

Práticas de sanitização devem sempre ser empregadas. Desinfestantes como hipoclorito de sódio, amônia quaternária, formaldeído e álcool são úteis para diminuir o inóculo nas edificações. A densidade de esporos do ar é diminuída pela remoção imediata de frutos infectados, pelo uso de exaustores e de um bom sistema de limpeza local.

Os benzimidazóis podem ser aplicados nos pomares até três semanas antes da colheita; em pós-colheita, no Brasil, o uso de fungicidas restringe-se aos benzimidazóis e ao imazalil. Um maior controle do bolor verde pós-colheita foi obtido com os fungicidas thiabendazole + imazalil aplicados em mistura a cera, comparado a aplicação em água, antes da cera (FISCHER et al., 2004) 
Problemas de resistência podem ser minimizados pelo uso alternado de fungicidas com diferentes modos de ação. Resfriamento imediato da embalagem diminui significativamente o bolor verde, particularmente quanto combinado com tratamentos fungicidas. Resultados promissores de indução de resistência ao patógeno $P$. digitatum vem sendo obtidos com ácido ß-aminobutírico (PORAT et al., 2003) e com a levedura Candida oleophila (DROBY et al., 2002) em frutos de pomelo, também com tratamento térmico em limão (KIM; YEHOSHUA, 2001) e pomelo (PORAT et al., 2000) e por fim com radiação ultravioleta em laranja (HALLEWIN et al., 1999) e pomelo (PORAT et al., 1999).

Dois agentes de controle biológico estão registrados comercialmente nos Estados Unidos e Israel para uso em pós-colheita no controle do bolor verde: "Aspire", cujo agente é Candida oleophila e "BioSave", cujo agente é Pseudomonas syringae. Embora estes agentes de controle biológico reduzam a incidência do bolor verde, a eficiência de controle ainda mostra-se inferior aos fungicidas thiabendazole e imazalil (BROWN; CAMBERS, 1996).

\subsubsection{Antracnose}

\subsection{Ocorrência}

Normalmente, a antracnose ocorre em frutos após a ocorrência de qualquer tipo de ferimento, como aqueles provocados por pragas. Em tangerinas, porém pode ocorrer infecção em frutos normais. A doença afeta todos os cítricos, tanto na embalagem quanto no armazenamento e na comercialização.

\subsection{Sintomatologia e epidemiologia}

As lesões são arredondadas, deprimidas e secas, de 1,5 a $3 \mathrm{~mm}$, de cor marrom-secura, com margem bem definida. Em condições de elevada umidade, formam-se os corpos de frutificação do fungo (acérvulos) de coloração alaranjada, nas superfície das lesões. Uma forma mais rara caracteriza-se por ligeira rugosidade do epicarpo, em listras, como se gotículas de orvalho tivessem deslizado sobre o fruto, 
deixando sua marca. A casca não se rompe e aparece manchada, de cor marrom escura nos frutos maduros e avermelhada nos frutos verdes.

\subsection{Etiologia}

A antracnose é causada por Colletotricum gloeosporiodes (Penz) Sacc, que produz conídios hialinos de 10 a $16 \mu \mathrm{m}$ x 5-7 $\mu \mathrm{m}$, em acérvulos superficiais, em ramos e frutos.

O patógeno penetra através de ferimentos. A infecção é favorecida por umidade elevada e a disseminação ocorre principalmente pela água de chuva. Em países de clima seco, este fungo não causa problemas. Nas plantações de limão, quando existe umidade elevada, os frutos podem ficar mumificados ou necrosados. Temperaturas abaixo de $10^{\circ} \mathrm{C}$ impedem o desenvolvimento da doença. $\mathrm{O}$ fungo sobrevive nos ramos secos e folhas senescentes (TUSET, 2000).

\subsection{Medidas de controle}

Medidas de prevenção da doença incluem a sanitização do pomar, por exemplo, a eliminação de galhos secos, que funcionam como fonte de inóculo. Os ramos devem ser removidos do pomar por ocasião do tratamento de inverno. Segundo Tuset (1987), a infecção ocorre geralmente em pré-colheita, justificando a necessidade de cuidados iniciais no campo.

O período de pós-colheita deve ser bastante curto, para evitar o aparecimento das lesões. Pode-se também realizar tratamento pós-colheita com fungicidas do grupo dos benzimidazóis e armazenar os frutos em câmaras frias, a fim de retardar o aparecimento das lesões. Os imidazóis mostram-se efetivos no controle químico da antracnose, particularmente contra isolados do fungo resistentes aos benzimidazóis (BENATO; CIA; SOUZA, 2001).

\subsubsection{Medidas de controle pós colheita em citros}

Os problemas derivados dos altos níveis de população fúngica ocorrendo em frutos de citros são significativamente maiores quando existem isolados dos patógenos resistentes aos fungicidas sintéticos. Foi principalmente a partir dos anos setenta que o 
problema de resistência passou a ser considerado importante (HOUCK, 1977). Desde então, muitos estudos têm constatado que o fenômeno de resistência é uma das principais causas do fracasso de muitos tratamentos com fungicidas de pós-colheita. $A$ grande maioria dos estudos se refere, por sua importância econômica, a P. digitatum e $P$. italicum frente aos fungicidas do grupo dos benzimidazóis, ortofenilfenato sódico e imazalil, e descrevem casos tanto de resistência simples como de resistência cruzada e múltipla (BROWN, 1982; ECKERT, 1990; BUS; BONGERS; RISSE, 1991). Em Valência, na Espanha, se estudou na década de oitenta a presença e as características de isolados de Penicillium spp. resistentes a diversos fungicidas (DÍAZ; VILLA; HERNÁNDEZ, 1987a, 1987b, DÍAZ; VILA, 1988, 1989). Através de levantamentos do ambiente de cinco packing-houses, pelo método gravimétrico em meio de cultura, Palou et al. (2001) constataram que $33 \%$ dos isolados de Penicillium apresentavam resistência ao fungicida thiabendazol e $5 \%$ ao imazalil. Dos isolamentos feitos das superfícies dos equipamentos e instalações dos packing-houses a resistência aos dois fungicidas foi de $5 \%$ e $20 \%$, respectivamente. Foram encontrados isolados resistentes tanto de $P$. digitatum como de $P$. italicum a ambos os fungicidas, embora a freqüência tenha sido baixa comparada com as outras espécies de Penicillium resistentes.

À medida que se tem questionado a aplicação de fungicidas sintéticos para o controle de doenças em pós-colheita, pela problemática dos efeitos à saúde e ao meio ambiente, tem-se desenvolvido o conceito de produção integrada e aumentado a importância dos métodos de controle preventivos. Entre eles podem citar-se os tratamentos culturais e/ou aplicações de fungicidas no campo, os tratamentos para a manutenção ou a melhora da resistência intrínseca dos frutos à infecção e a correta higienização dos packing-houses de citros (BROWN, 1980; ECKERT; EAKS, 1989). Redução superior a $50 \%$ na incidência de podridões pós-colheita, após o período de armazenamento a $10^{\circ} \mathrm{C}$, foi observada em frutos cítricos que receberam aplicação de tiofanato metílico em pré-colheita (RITENOUR et al., 2004). Identificar e quantificar a contaminação fúngica presente nas distintas partes do packing-house, assim como estudar a presença de isolados resistentes é importante para se estabelecer riscos potenciais de danos e desenhar sistemas adequados de controle. 
A presença das doenças pós-colheita pode estar associada a uma colheita precipitada, mal programada, e a uma precária ou nula seleção dos frutos no packinghouse (TUSET, 1987). No armazenamento, pode ocorrer disseminação e infecção de frutos sadios por contato com frutos doentes. Portanto, o manuseio cuidadoso de frutos durante as operações de colheita, transporte, processamento e armazenamento é prática recomendada.

A regulação do ambiente pelo uso de câmaras frias no armazenamento e containers refrigerados no transporte dos frutos beneficiados é prática importante para a redução das doenças em pós-colheita. A temperatura utilizada para a conservação depende da variedade cítrica a ser armazenada. Em termos gerais, recomenda-se para pomelos, limões verdadeiros e limas temperaturas de armazenamento entre 10 e $12^{\circ} \mathrm{C}$, para as tangerinas entre 5 e $7^{\circ} \mathrm{C}$ e para os diferentes tipos de laranja doce entre 2 e 4 ${ }^{\circ} \mathrm{C}$, com umidade relativa do ambiente entre 90 e 95 \% (BENATO; CIA; SOUZA, 2001).

A utilização de concentrações elevadas de etileno, acima do requerido, no processo de desverdecimento, pode contribuir para a expressão dos sintomas das doenças pós-colheita (WHITESIDE; GARNSEY; TIMMER, 1993). O desverdecimento parece aumentar a suscetibilidade das frutas às podridões, particularmente quando a duração do tratamento é excessiva, a concentração de etileno empregada é muito alta e/ou a temperatura utilizada é demasiadamente elevada (MAZZUZ, 1996; PETRACEK; MONTALVO, 1997). A ocorrência de podridões durante e após o desverdecimento pode ser minimizada através da aplicação de fungicidas antes ou após o tratamento. Cohen (1983) indicou o tratamento com thiabendazole (500 mg/L), por imersão, antes do desverdecimento de tangerinas 'Satsuma' como forma de reduzir as podridões. Petracek; Montalvo (1997) comentaram que, para reduzir a incidência de fungos provocada pela exposição de tangerinas ao etileno, como C. gloeosporioides e Diplodia sp., os frutos devem ser retirados da câmara pouco antes de alcançarem o pleno desverdecimento. O armazenamento refrigerado das frutas após o desverdecimento também pode reduzir os problemas advindos do processo, considerando que um dos efeitos da frigoconservação é retardar o desenvolvimento de patógenos causadores de podridões (CHITARRA; CHITARRA, 1990). Os estudos de conservação pós-colheita de frutas cítricas desverdecidas é importante, pois pode determinar a durabilidade da fruta 
durante o transporte a longas distâncias, como no caso de exportação, e proporcionar o prolongamento do período de comercialização.

É importante dentro das técnicas a serem utilizadas na pós-colheita, ter em conta as características típicas de cada variedade cítrica, a distância que será percorrida até o destino e a legislação vigente de cada país importador, quanto aos produtos e resíduos permitidos (MAZZUZ, 1996).

Muitos dos problemas encontrados na exportação de frutas cítricas, ligados à sanidade dos frutos são devidos a algumas práticas normalmente utilizadas na pré e pós-colheita. O fornecimento de frutos saudáveis e utilizando menores quantidades de fungicidas são práticas que poderiam ser adotadas, as quais aumentariam o interesse pelo consumo de frutos.

\subsubsection{Indução de resistência}

A indução de resistência (IR) pode resultar de uma infecção limitada do patógeno, particularmente quando a planta desenvolve uma reação de hipersensibilidade (VAN LOON; BAKKER; PIETERSE, 1998), o que envolve a ativação dos mecanismos bioquímicos e estruturais de defesa. A IR também pode ser desencadeada por inúmeros agentes, denominados indutores e, geralmente, mostra-se sistêmica (HAMMERSCHMIDT, 1999). Segundo Hammerschmidt (1999), devido a esta característica, a indução de resistência é geralmente definida como resistência sistêmica adquirida (RSA).

Os frutos possuem mecanismos estruturais e bioquímicos que podem contribuir para a resistência dos mesmos contra patógenos (PASCHOLATI; LEITE, 1995), envolvendo a ativação de mecanismos latentes de resistência através do uso de agentes bióticos ou abióticos (HAMMERSCHMIDT; DANN, 1997). Outro aspecto interessante da indução de resistência é a ausência de especificidade, refletida pelos diferentes indutores passíveis de uso e pelo amplo espectro de fitopatógenos contra os quais o fruto é protegido e, a proteção local ou sistêmica, a qual ocorre à distância do sítio de aplicação do indutor e inoculação do patógeno (STICHER; MAUCH-MANI; MÉTRAUX, 1997). 
Nas interações patógeno-hospedeiro, o patógeno utiliza substâncias químicas (enzimas, toxinas, hormônios) para atacar o hospedeiro que por sua vez, procura se defender através de mecanismos estruturais ou bioquímicos, que podem ser subdivididos em pré-formados e pós-formados, sendo que os últimos é que se mostram de interesse no fenômeno de indução de resistência (PASCHOLATI; LEITE, 1995). Dentre os mecanismos pré-formados estruturais, estão a presença de cutícula, tricomas, tipo de estômatos, fibras e forma dos vasos condutores. Entre os bioquímicos, estão os fenóis, alcalóides, lactonas insaturadas, glicosídeos fenólicos, fototoxinas e inibidores protéicos. Nos pós-formados, também chamados induzíveis, podemos encontrar mecanismos estruturais, como papilas, halos, lignificação, camadas de cortiça, calose, e tiloses em vasos, enquanto nos bioquímicos, fitoalexinas, proteínas-RP, glicoproteínas ricas em hidroxiprolina, inibidores de proteases, peroxidases, entre outros (PASCHOLATI; LEITE, 1994).

Praticamente, são poucos os relatos sobre experiências realizadas com o uso de agentes alternativos de controle em citros em pós-colheita, principalmente em indução de resistência, sendo encontradas apenas informações sobre o comportamento de diversos frutos expostos aos tratamentos térmico, radiação (UV-C) e gama, utilização de quitozana, Acibenzolar-S-metil (ASM), e ozônio, havendo poucos trabalhos relacionados com indutores bióticos (CAMILI; CIA; BENATO, 2005). Dessa maneira, existe-se uma necessidade de agentes bióticos como potenciais indutores de resistência em frutos cítricos.

\subsubsection{Agentes bióticos e abiótico de controle e indutores}

\subsubsection{Agentes bióticos}

\subsection{Lentinula edodes}

L. edodes, conhecido como cogumelo "Shiitake", é um basidiomiceto cujo corpo de frutificação é amplamente utilizado na culinária asiática, sendo difundido atualmente a nível mundial, incluindo o Brasil (PASCHOLATI; STANGARLIN; PICCININ, 1998). São inúmeros os trabalhos que mencionam compostos oriundos de L. edodes com ação 
sobre vírus, bactérias e fungos patogênicos a animais e plantas. Por exemplo, Pacumbaba; Beyl; Pacumbaba, (1999) demonstraram que o exsudato de L. edodes inibiu significativamente $\mathrm{o}$ crescimento de todas as espécies de bactérias fitopatogênicas testadas, incluindo $P$. syringae pv. glycinea, $P$. syringae pv. tabaci, Xanthomonas campestris pv. glycines, Erwinia amylovora, X. campestris pv. campestris, Ralstonia solanacearum e Curtobacterium flaccumfaciens pv. flaccumfaciens, além do crescimento de bactérias que afetam alimentos e animais, como B. cereus, Escherichia coli, Listeria monocytogenes, Salmonella typhimurium e Staphylococcus aureus. No tocante ao efeito sobre fungos fitopatogênicos, os extratos obtidos a partir da massa micelial de L. edodes, dependendo da concentração utilizada, inibiram o desenvolvimento in vitro dos fungos Helminthosporium sp. e Fusarium solani, agentes causais da helmintosporiose do trigo e da síndrome da morte súbita em soja, respectivamente (SASAKI, 1997), bem como de Phomopsis sojae, agente causal da seca das hastes e das vagens em soja. Piccinin (2000) mostrou também que o filtrado obtido a partir da massa micelial de $L$. edodes, bem como os filtrados obtidos a partir do píleo e da estipe do cogumelo, reduziram significativamente o crescimento micelial de Exserohilum turcicum e Colletotrichum sublineolum a partir da concentração de 10.000 $\mu \mathrm{g} / \mathrm{mL}$ de filtrado no meio de cultivo. A $20.000 \mu \mathrm{g} / \mathrm{mL}$ os filtrados reduziram a esporulação dos patógenos. Di Piero e Pacholati, (2004b) demonstraram que o extrato aquoso do basidiocarpo reduziu a severidade da antracnose (Colletotrichum lagenarium) em plantas de pepino nas condições de casa de vegetação.

\subsection{Agaricus blazei}

A. blazei, um cogumelo nativo do Brasil, tem sido amplamente consumido em diferentes partes do mundo devido às suas propriedades medicinais (PASCHOLATI; STANGARLIN; PICCININ, 1998). O cogumelo vem sendo cultivado comercialmente no Brasil desde o início da década de 90 e a maior produção encontra-se no estado de São Paulo, onde o cultivo principal é feito nas épocas de primavera e verão (BRAGA et al., 1998). No Japão, a produção anual varia de 100 a 300 toneladas de basidiocarpo seco (TAKAKU; KIMURA; OKUDA, 2001). 
Segundo Mizuno et al. (1990), o basidiocarpo de A. blazei apresenta 40-45\% de proteínas, $38-45 \%$ de carboidratos, $6-8 \%$ de fibras, $5-7 \%$ de minerais e $3-5 \%$ de gordura, valores baseados em relação à matéria-seca. Contém ainda as vitaminas B1, B2 e niacina e teores elevados de potássio e cálcio. Além das propriedades nutricionais, A. blazei é utilizado por aproximadamente 500.000 pessoas para prevenção do câncer ou como um adjuvante no tratamento com drogas quimioterápicas, após a remoção de um tumor maligno (TAKAKU; KIMURA; OKUDA, 2001). Segundo Eguchi et al. (1999), o extrato aquoso de basidiocarpo de $A$. blazei pode ser um alimento útil para o tratamento preventivo e curativo de disfunções renais.

Vários compostos de interesse medicinal já foram caracterizados (MIZUNO, 1995b). Compostos antitumorais incluem polissacarídeos, complexos proteínapolissacarídeos, esteróides, presentes tanto no basidiocarpo como no micélio. Kawagishi et al. (1990) obtiveram um complexo gluco-protéico, com um alto conteúdo dos aminoácidos alanina e leucina, apresentando atividade antitumoral. $O$ efeito, caracterizado pela inibição do crescimento de sarcoma-180 implantado em camundongos, ocorreu provavelmente devido às propriedades imuno-regulatórias do complexo. Mizuno et al. (1990) demostraram efeito similar a partir de polissacarídeos obtidos a partir do extrato aquoso do basidiocarpo, destancando-se o complexo 1,6- e

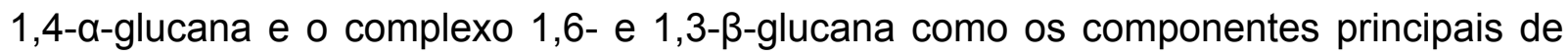
diferentes polissacarídeos. Por sua vez, os polissacarídeos isolados a partir de extrato aquoso do micélio de $A$. blazei, que apresentaram atividade antitumoral, foram diferentes dos polissacarídeos antitumorais isolados do basidiocarpo do cogumelo (MIZUNO et al., 1999).

Atividade antimutagênica em Salmonella foi encontrada em extratos hexânicos do basidiocarpo e atribuída ao ácido linoléico (OSAKI et al., 1994). Por sua vez, os extratos aquosos mostraram-se antimutagênicos quando testados em células V79 de hamster chinês (MENOLI et al., 2001).

Em relação aos efeitos protetores do cogumelo sobre fitopatógenos, Di Piero e Pascholati (2004b) demonstraram que o extrato aquoso inibiu em média $50 \%$ a severidade da antracnose (Colletotrichum lagenarium) em plantas de pepino em condições de casa de vegetação. Além disso, também diminuiu a severidade da 
mancha bacteriana (Xanthomonas vesicatoria) em plantas de tomate (DI PIERO; PACHOLATI, 2004a).

\subsection{Albedo de Citrus sinensis var. Valência e flavedo de Citrus aurantifolia var. Tahiti}

A casca dos citros é caracterizada por duas partes: o exocarpo, a mais externa, designada como "flavedo" constituído pela epiderme e por uma camada de células glandulares de óleo, onde podem ser encontrados os carotenóides, vitaminas e óleos essênciais, e o mesocarpo, constituído por uma camada de células esponjosas brancas denominada de "albedo", onde podem ser encontrados carboidratos solúveis, aminoácidos, vitaminas, pectina e flavonóides.

O uso do extrato do albedo, flavedo e endocarpo de laranjas na inibição do crescimento micelial de Phomopsis citri, agente causal da melanose, foi relatado por ElTobshy; Sinclair (1964). Os resultados mostraram que na presença dos extratos de flavedo e albedo juntos e somente na presença do extrato de albedo ocorria a inibição do crescimento fúngico, justificando a importância do albedo.

Murdoch e Allen (1960), citados em Brodrick e Rabie (1970), relataram que o limoneno obtido da casca de laranja, em concentrações variando de 0,02 a 0,1\%, foi tóxico ao fungo Zygosaccharomyces sp. Em 1970, Brodrick e Rabie também relataram o potencial do limoneno, extraído do albedo e do flavedo de laranja, para o controle de G. citricarpa, comprovando o efeito antifúngico deste composto. Porém, nenhum experimento ou estudo foi conduzido para outras doenças de pós-colheita em citros, como bolores e antracnose.

Cardoso Filho (2003) demonstrou que o flavedo de Citrus sinensis var. Pêra é promissor no controle de G. citricarpa, pois os resultados in vitro evidenciaram um atraso no crescimento micelial e na esporulação do patógeno, quando comparados com o controle. Através destes trabalhos, o autor demostrou que extratos de origem vegetal exibem um grande potencial como agentes antimicrobianos.

O uso do extrato do flavedo de limão-tahiti, baseia-se no fato do mesmo ser tolerante aos patógenos em estudo, principalmente ao fungo G. citricarpa, onde, foi possível constatar a presença desse patógeno no flavedo, porém não ocorrendo a 
expressão de sintomas. O limão-tahiti é um híbrido do siciliano com a lima-da-pérsia, sendo conhecido como laranja-azeda ou lima-ácida, quando mencionada sua tolerância em relação aos patógenos (FEICHTENBERGER et al., 2005). Porém, o termo limãotahiti é usado devido a popularização do nome, mas na verdade é uma lima-ácida. Estudos químicos do flavedo de limão-taiti demonstram que a constituição do óleo essencial é a seguinte: d-limoneno ( 51 - $60 \%)$, $\alpha$-pineno $(4,3$ - 5,0 \%), $\gamma$-terpineno (1,3 - 8,5 \%), $\rho$-cimeno (1,2 - 10,4 \%), mirceno (0,9 - 1,8 \%). O limão também possui um bioflavonóide chamado hesperidina. O óleo essencial é utilizado como aromatizante na indústria alimentícia, farmacêutica, perfumaria e cosméticos, porém não se encontra nenhum relato da sua utilização direta na agricultura (BARROS; YABIKU; PINTO, 1986).

\subsubsection{Agente abiótico}

\subsubsection{1 Ácido jasmônico}

Os jasmonatos (ácido jasmônico e o seu éster volátil denominado metil jasmonato) são lipídeos oxigenados, gerados pela via dos octadecanóides (BOSTOCK 1999), estando presentes em diversas plantas. Esses compostos são produzidos nas plantas após injúrias ou tratamentos com elicitores (ATHAYDE SOBRINHO; FERREIRA; CAVALCANTI, 2005), apresentando funções hormonais e de defesa contra fitopatógenos e insetos. A ação de defesa está ligada à capacidade de induzir a síntese ou acúmulo de proteínas inativadoras de ribossomos, fenilalanina amônia-liase, sintase da chalcona, proteínas ricas em prolina, inibidores de proteinase e outros fatores como polifenoloxidases e lipoxigenases (KOZLOWISKI; BUCHALA; METRAUX, 1999).

Mediante diversos estudos têm-se verificado a importância dos jasmonatos na resposta de defesa das plantas contra fitopatógenos (BOSTOCK, 1999). O efeito pode estar ligado diretamente a sua atividade inibitória sobre a formação de apressórios ou na indução do acúmulo de compostos com efeito antimicrobiano, como as defensinas. Em trabalho recente, Kozlowski; Buchala; Metraux (1999) demonstraram a capacidade do jasmonato de metila na indução de resistência em Picea abies contra Pythium ultimum. O interessante desse trabalho é que o tratamento elicitor não induziu o 
acúmulo de jasmonatos, mas sim a síntese de ácido salicílico e de quitinase. Nesse caso em particular, o acúmulo de quitinase não deve estar diretamente ligado ao controle do fungo, já que este é um Oomiceto e a quitinase é expressa constitutivamente em raízes de $P$. abies.

\subsection{Objetivos}

Avaliar o efeito antifúngico in vitro dos extratos do albedo de $C$. sinensis var. Valência e flavedo de C. aurantifolia var. Tahiti, sobre G. citricarpa, P. digitatum e C. gloeosporioides;

Avaliar o potencial dos extratos do albedo de C. sinensis, flavedo de $C$. aurantifolia, Lentinula edodes, Agaricus blazei e ácido jasmônico como possíveis agentes de controle dos patógenos e de indução de resistência em frutos de laranja ( $C$. sinensis var. Valência).

\subsection{Material e métodos}

\subsubsection{Influência do albedo e do flavedo no desenvolvimento in vitro de $G$. citricarpa, $P$. digitatum e C. gloeosporioides}

\subsubsection{Obtenção e cultivo dos fitopatógenos}

Para a obtenção dos fungos G. citricarpa e C. gloeosporioides foram realizados isolamentos à partir de laranjas coletadas em diferentes regiões produtoras. Foram obtidos fragmentos do tecido lesionado do fruto, procedendo-se a assepsia em álcool etílico $70 \%$ durante $30 \mathrm{~s}$, e hipoclorito de sódio $1,5 \%$ por $60 \mathrm{~s}$. Os fragmentos foram lavados em água destilada esterilizada e colocados em papel-filtro para retirada do excesso de umidade. Os fragmentos foram então transferidos para placas de petri contendo BDA (bata-dextrose-ágar) e incubados a $25^{\circ} \mathrm{C}$ até o aparecimento de colônias. Quanto ao $P$. digitatum, a obtenção do patógeno foi efetuada da mesma maneira acima, porém o isolamento não necessitou dos processos de assepsia, pois a formação de estruturas do patógeno é superficial, havendo a retirada dos conidióforos e conídios com uma alça e transferência para o BDA e incubação até a obtenção de colônias. 


\subsubsection{Obtenção dos materiais para os experimentos envolvendo compostos voláteis}

Frutos, com idade aproximada de 10 meses, de laranja Valência (C. sinensis), assintomáticos, foram coletados de plantas adultas na fazenda Oriçanga situada no município de Mogi-Guaçu. Por sua vez, os frutos de limão-Tahiti (C. aurantifolia) sadios foram coletados também de plantas adultas situadas na Fazenda Areão no município de Piracicaba, sendo os mesmos com idade aproximada entre 8 e 10 meses. Dos frutos foram separados o albedo e o flavedo utilizando-se uma máquina descascadora e uma faca, e triturados em liquidificador (sem água). Utilizou-se o albedo de laranja Valência e o flavedo de limão Tahiti. Em placas de poliestireno $(9 \mathrm{~cm} \varnothing)$, as quais possuem uma divisão que não permite o contato do material que está de um lado da placa com o material que está do outro, em condições assépticas, foi vertido meio BDA em uma das metades e posteriormente após sua solidificação, foram repicados os fungos. Após repicagem, foram colocados na outra metade da placa $5 \mathrm{~g}$ de albedo triturado. A placa de poliestireno quando fechada, apresenta um espaço entre a divisão e a tampa, o qual possibilita trocas gasosas entre os dois lados. O material foi incubado em temperatura de $25^{\circ} \mathrm{C}$ e em fotoperíodo (luz fluorescente) de $12 \mathrm{~h}$. A instalação do experimento com o flavedo foi igual a anterior. Foram realizados quatro repetições para cada patógeno, sendo a testemunha apenas o meio BDA com o patógeno, estando a outra metade da placa isenta do albedo ou flavedo. Foram realizadas avaliações, medindo-se o crescimento micelial, com o auxílio de um paquímetro de 48 em 48 horas, até que o micélio tomasse a meia placa onde foi repicado.

\subsubsection{Obtenção dos extratos etanólicos e detecção da atividade antifúngica}

No Laboratório de Fisiologia e Bioquímica fitopatológica, Setor de Fitopatologia/ ESALQ/USP, nos frutos da mesma procedência descrita no item anterior, foi efetuada a separação do flavedo e albedo com auxílio de uma máquina descascadora e uma faca. Em seguida, após a separação, o peso da matéria fresca do albedo e do flavedo foi determinado e o material homogeneizado separadamente em liquidificador na menor velocidade, durante $1 \mathrm{~min}$, e a massa fresca novamente determinada. Após secagem em estufa $\left(65^{\circ} \mathrm{C}\right.$ até peso constante), para cada grama de albedo ou flavedo seco, foi 
adicionado $1 \mathrm{~mL}$ de álcool etílico P.A. Logo após, os homogeneizados (pó seco do albedo ou flavedo + solventes) foram aquecidos em banho-maria (60 ${ }^{\circ} \mathrm{C}$ durante 10 min), sendo filtrados em papel de filtro Whatman no.1, e em seguida reduzidos próximo à secura em evaporador rotativo a $40{ }^{\circ} \mathrm{C}$, sob vácuo e finalmente liofilizados e armazenados em geladeira $\left(5-10^{\circ} \mathrm{C}\right)$ até o uso.

\subsection{Influência no crescimento micelial}

A partir de soluções estoque (100 mg/ $\mathrm{mL} \mathrm{H}_{2} \mathrm{O}$ destilada) do liofilizado dos extratos, foram retiradas alíquotas de $1 \mathrm{~mL}$ que foram usadas no preparo das diluições 0.01, 0.1, 1 e $10 \mathrm{mg} / \mathrm{mL}$ em água destilada esterilizada. Posteriormente, $1 \mathrm{~mL}$ de cada diluição foi colocado sobre placas de Petri contendo BDA solidificado. Em seguida, após $24 \mathrm{~h}$, discos de micélio de 0,6 cm de diâmetro dos patógenos (cultivados em BDA) foram transferidos para o centro das placas contendo BDA mais extrato ou BDA acrescido de $1 \mathrm{~mL}$ de $\mathrm{H}_{2} \mathrm{O}$ destilada esterilizada, no caso da testemunha. Inicialmente, foram utilizadas 5 placas por repetição. Os patógenos foram mantidos a $25{ }^{\circ} \mathrm{C}$, sob luz fluorescente, com alternância de luminosidade (12 h claro e $12 \mathrm{~h}$ escuro) sendo determinado o diâmetro das colônias, utilizando-se um paquímetro. Esta metodologia foi aplicada para os três patógenos em estudo.

\subsection{Influência na germinação de esporos e formação de apressório}

A partir das soluções estoques dos extratos foram preparadas diluições $(0,01$ a $10 \mathrm{mg} / \mathrm{mL}$ ) em água destilada esterilizada. Logo após, alíquotas de $20 \mu \mathrm{l}$ das diluições foram retiradas e misturadas com $20 \mu$ le suspensões de esporos dos fungos $\left(1 \times 10^{5}\right.$ esporos $\mathrm{mL}$ e Tween 80 0,1\%) e colocadas em lâminas de microscopia recobertas com filme de poliestireno (LEITE; NICHOLSON, 1992). Como controle foi utilizada água destilada esterilizada. A seguir, as lâminas foram colocadas no interior de placas de Petri (9 cm de diâmetro) esterilizadas, contendo um chumaço de algodão embebido em água destilada, seladas com filme PVC e incubadas em câmara de crescimento à temperatura de $25^{\circ} \mathrm{C}$, com luminosidade alternada (12 h claro $12 \mathrm{~h}$ escuro) por $24 \mathrm{~h}$. Após este período, a porcentagem de germinação foi avaliada através da observação em microscópio óptico (aumento de 200 x). Foram considerados como germinados os 
esporos com tubo germinativo de tamanho igual ou superior ao comprimento dos esporos não germinados.

\subsubsection{Influência dos agentes bióticos e abiótico nas interações com G. citricarpa,}

P. digitatum e C. gloeosporioides em frutos de C. sinensis var. Valência

\subsubsection{Obtenção e cultivo dos fitopatógenos}

Para obtenção do fungo $P$. digitatum e C. gloeosporioides, foram realizados isolamentos em meio ágar - água, diretamente de sinais do patógeno presente em frutos de laranja Valência, e posteriormente, repicados para meio BDA. Entre sete e dez dias (fotoperíodo de $12 \mathrm{~h}$ a $25^{\circ} \mathrm{C}$ ), as placas estavam prontas para serem utilizadas.

O fungo $G$. citricarpa foi isolado a partir de lesões do tipo mancha dura, em meio ágar - água, e posteriormente repicado em meio BDA. As placas foram mantidas sob fotoperíodo de $12 \mathrm{~h}$ a temperatura de $25^{\circ} \mathrm{C}$. Este isolamento ocorreu de frutos provenientes da área onde ocorreu a coleta para os ensaios in vivo.

\subsubsection{Obtenção e preparo do Lentinula edodes}

Os cogumelos (Shiitake) foram produzidos no Departamento de Produção Vegetal (Módulo de Cogumelos), da Faculdade de Ciências Agrárias/ UNESP/ Botucatu, sob responsabilidade do Prof. Dr. Augusto Ferreira da Eira. Os basidiocarpos do isolado de shiitake (LE 96/22), utilizado para a elaboração do experimento, foram obtidos de acordo com Pacholati; Stangarlin e Piccinin (1998). O cultivo do cogumelo foi em toras de eucalipto da espécie Eucaliptus grandis, em local sombreado, no campo. As principais etapas desse cultivo envolveram: i) produção de "inóculo" (crescimento vegetativo) em meio sintético; ii) "inoculação" das toras de eucalipto; iii) incubação; iv) choque térmico e hídrico para induzir os primórdios de basidiocarpo; v) colheita e processamento dos basidiocarpos. Para a obtenção do extrato aquoso, o pó seco de basidiocarpo recebeu água (14 $\mathrm{mL}$ para cada grama), e após 24 horas de incubação a $4^{\circ} \mathrm{C}$, a suspensão foi filtrada em filtro comum (gramatura: $8 \mathrm{~g} / \mathrm{cm}^{2}$ ) e o extrato foi utilizado nos testes de proteção de frutos de $C$. sinensis var. Valência. 


\subsubsection{Obtenção e preparo do Agaricus blazei}

Estes cogumelos também foram produzidos no Módulo de Cogumelos/ UNESP. Porém, os basidiocarpos do isolado de A. blazei (ABL 28) foram provenientes de cultivo axênico, realizado em substrato mantido no interior de câmaras de produção, onde os fatores ambientais são totalmente controlados. As etapas de cultivo envolveram: i) preparo do substrato de cultivo (bagaço de cana, capim de gramíneas, farelo de soja, enriquecido com sais minerais) através da compostagem e da pasteurização; ii) adição de micélio do cogumelo junto ao substrato; iii) colonização do substrato; iv) cobertura do substrato com turfa Santa Catarina, para induzir a formação dos primórdios de basidiocarpo; v) colheita e processamento dos basidiocarpos (PASCHOLATI, STANGARLIN; PICCININ, 1998). Para a obtenção do extrato aquoso, o pó seco de basidiocarpo recebeu água ( $14 \mathrm{~mL}$ para cada grama), e após 24 horas de incubação a $4^{\circ} \mathrm{C}$, a suspensão foi filtrada em filtro comum (gramatura: $8 \mathrm{~g} / \mathrm{cm}^{2}$ ) e utilizado nos testes.

\subsubsection{Obtenção e preparo do albedo e do flavedo}

Frutos, com idade aproximada de 10 meses, de laranja Valência (C. sinensis), assintomáticos, e frutos da lima ácida (Tahiti) foram coletados de plantas adultas. No laboratório, a separação do flavedo e albedo foi efetuada com auxílio de uma máquina manual descascadora, a qual retirou o flavedo e posteriormente uma faca, com a qual retirou-se o albedo. Posteriormente, o albedo ou mesocarpo de $C$. sinensis var. Valência e o flavedo ou epicarpo de C. aurantifolia var. Tahiti foram desidratados em ambiente seco e sombreado, a temperatura ambiente. Após a secagem, os materiais foram moídos em moedor do tipo martelo e transformados em pó. Para a obtenção do extrato aquoso, o pó seco do albedo e do flavedo recebeu água (10 $\mathrm{mL}$ para cada grama), sendo a suspensão filtrada em filtro comum (gramatura: $8 \mathrm{~g} / \mathrm{cm}^{2}$ ) e utilizada nos testes.

\subsubsection{Obtenção e preparo do ácido jasmônico}

O ácido jasmônico foi obtido junto a Sigma Chemical Co., sendo inicialmente dissolvido em $1 \mathrm{ml}$ de acetona e subseqüentemente misturado com 8 litros de água 
(THALER, 1999). A concentração final foi de 0,5 mM. Esta concentração foi utilizada no tratamento de frutos de laranja Valência.

\subsubsection{Influência dos agentes bióticos e abiótico sobre a mancha preta dos citros}

A coleta e a realização dos experimentos foi iniciada na safra de laranja Valência no ano de 2004, tendo continuidade na safra de 2005. Os extratos aquosos do albedo de C. sinensis, flavedo de C. aurantifolia, L. edodes (Shiitake) e A. blazei (Cogumeloda-vida) foram testados no controle pós-colheita da mancha preta em frutos de $C$. sinensis var. Valência. Foram também incluídos um tratamento com água e um com o fungicida Thiabendazole (800 ppm).

O delineamento utilizado foi inteiramente casualizado, utilizando-se 10 frutos em cinco repetições, em um total de 50 frutos por tratamento. Os frutos de laranja sintomáticos (inóculo de campo) foram coletados na Fazenda Oriçanga, situada no município de Mogi-Guaçu (SP). Posteriormente, foram lavados com água e submetidos a desinfestação superficial utilizando-se hipoclorito de sódio (200 ppm). As lesões existentes foram marcadas com o auxílio de uma caneta para retro-projetor, para avaliação das novas lesões (Figura 2). Os frutos foram tratados via aspersão, em uma

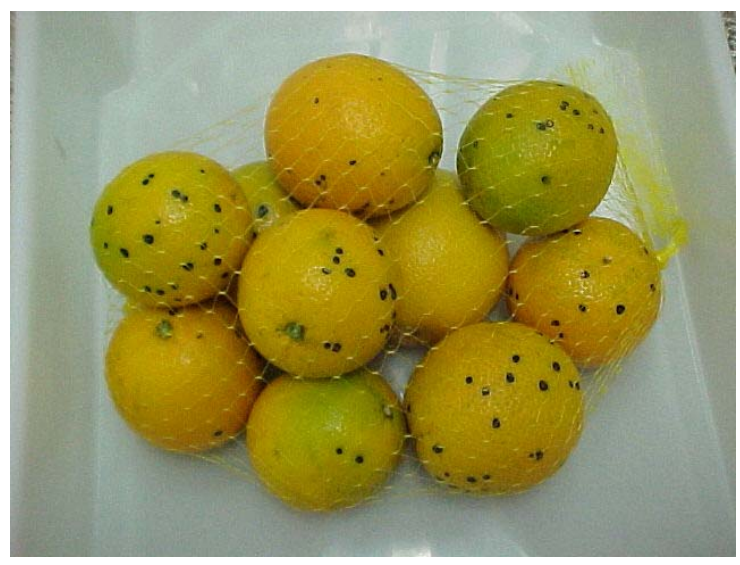

Figura 2 - Frutos com lesões oriundas do campo que foram marcadas com caneta para retro-projetor

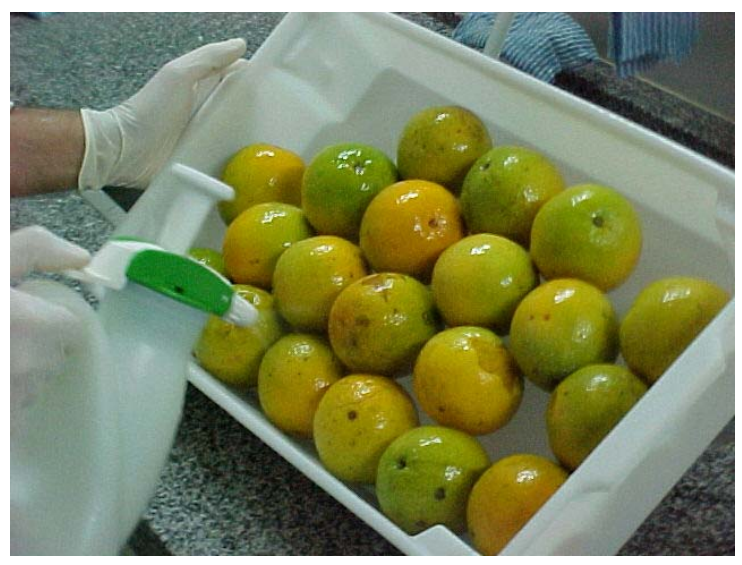

Figura 3 - Procedimento para a aspersão dos frutos de Citrus sinensis var. Valência

caixa plástica branca rasa $(80 \times 40 \times 15 \mathrm{~cm})$, e posteriormente, virados para que toda a superfície dos frutos fosse tratada, sendo utilizado $100 \mathrm{~mL}$ de calda por tratamento (Figura 3). Após a secagem, os frutos foram mantidos em câmara controlada a $25^{\circ} \mathrm{C} \mathrm{e}$ 
$85 \%$ UR por 15 dias. Neste período foram realizadas quatro avaliações (5, 9, 12 e 15 dias), sendo realizada a contagem do número de novas lesões. A cada avaliação, novas lesões eram contadas e marcadas, sendo que na última avaliação (décimo quinto dia) todas as lesões existentes nos frutos estavam marcadas. Dois experimentos utilizando as mesmas metodologias e o mesmo número de frutos foram realizados.

\subsubsection{Influência dos agentes bióticos e abiótico sobre o bolor verde dos citros}

A coleta e a realização dos experimentos foi iniciada na safra de laranja Valência, no ano de 2004, tendo continuidade na safra de 2005. Os extratos aquosos do albedo de C. sinensis, flavedo de C. aurantifolia, L. edodes (Shiitake), A. blazei (Cogumelo-da-vida) e o agente abiótico ácido jasmônico, foram testados no controle pós-colheita de $P$. digitatum em frutos de $C$. sinensis var. Valência. Foram também incluídos um tratamento com água e um com o fungicida Thiabendazole (800 ppm).

O delineamento utilizado foi inteiramente casualizado, utilizando-se 10 frutos com 4 repetições, totalizando 40 frutos por tratamento e 270 frutos por experimento. Foram realizados quatro experimentos, totalizando 1080 frutos, que diferiram no momento de aplicação dos agentes. No primeiro, os agentes foram aplicados nos frutos e logo após a secagem foi efetuada a inoculação do patógeno (Protetor). No segundo experimento foi efetuada a inoculação e logo após a secagem da gota do inóculo, efetuou-se a aplicação dos agentes (Erradicante). No terceiro, os frutos foram inoculados e $24 \mathrm{~h}$ depois tratados (Curativo). E no último experimento, os frutos foram tratados e após 48 h, inoculados com o patógeno (Indução de resistência). Nos dois últimos experimentos, os frutos, enquanto aguardavam a aplicação dos agentes ou do inóculo, permaneceram em câmara controlada ( $25^{\circ} \mathrm{C}$ a $85 \%$ UR), nas mesmas condições até o final dos testes.

Frutos de laranja foram coletados na Fazenda Oriçanga, situada no município de Mogi-Guaçu (SP). Posteriormente foram lavados com água e submetidos a desinfestação superficial utilizando hipoclorito de sódio (200ppm). A inoculação nos frutos foi efetuada, a partir de um ferimento feito com um sistema de três agulhas. As agulhas estavam em um suporte de borracha e colocadas a uma distância de $1 \mathrm{~mm}$ cada e a profundidade da lesão causada na casca dos frutos era de aproximadamente 
2 a $3 \mathrm{~mm}$ (Figura 4). Os frutos foram inoculados com uma suspensão de esporos (1x $10^{5}$ ), a partir de uma gota de $20 \mu \mathrm{L}$, a qual era colocada no local do ferimento.

Os frutos foram tratados com as diferentes preparações via aspersão, em uma caixa plástica branca rasa $(80 \times 40 \times 15 \mathrm{~cm})$, e posteriormente, virados para que toda a superfície dos frutos fosse tratada, tendo-se utilizado $100 \mathrm{~mL}$ de calda por tratamento (Figura 3). A seguir, os frutos foram mantidos em câmara controlada a $25^{\circ} \mathrm{C}$ e $85 \%$ UR por 8 dias. Neste período foram realizadas seis avaliações (3, 4, 5, 6, 7, 8 dias), sendo realizada a contagem do número de frutos doentes (exibindo sintomas de podridão) e o número de frutos que apresentavam esporulação na superfície da casca (sinais do patógeno) (Figura 5).

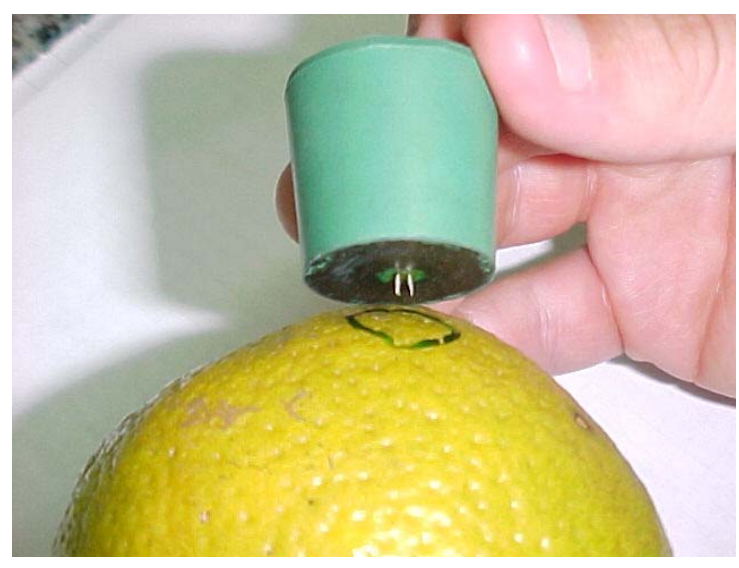

Figura 4 - Detalhes da ferramenta utilizada para causar ferimentos em frutos de Citrus sinensis var. Valência, quando da inoculação de Penicillium digitatum

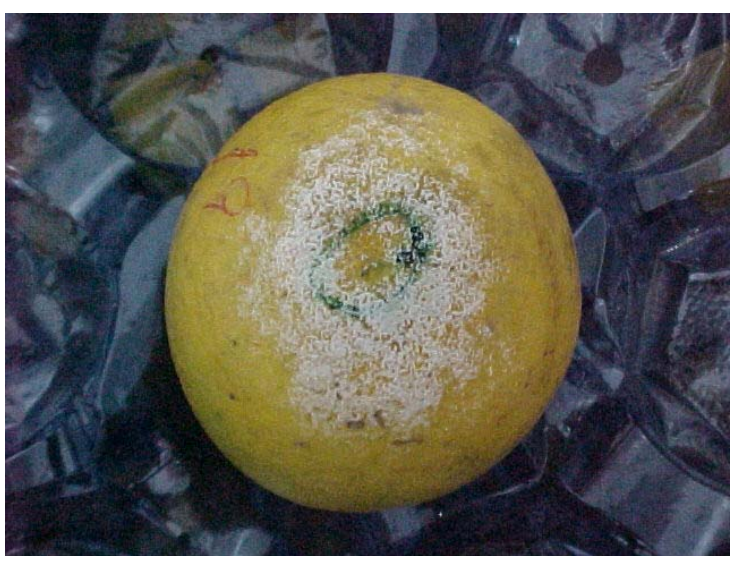

Figura 5 - Fruto de C. sinensis var. Valência apresentando esporulação de Penicillium digitatum

\subsubsection{Influência dos agentes bióticos e abiótico sobre a antracnose}

Experimentos envolvendo a doença antracnose, tendo como agente causal o fungo C. gloeosporioides, também foram realizados. Os extratos aquosos do albedo de C. sinensis, flavedo de C. aurantifolia, L. edodes (Shiitake), A. blazei (Cogumelo-davida) e o agente abiótico ácido jasmônico, foram testados no controle pós-colheita em frutos, de aproximadamente 10 meses, de C. sinensis var. Valência. Foram também incluídos um tratamento com água e um com o fungicida Thiabendazole (800 ppm).

O delineamento utilizado foi inteiramente casualizado, utilizando-se 10 frutos com 4 repetições, totalizando 40 frutos por tratamento e 270 frutos por experimento. Foram 
realizados quatro experimentos, totalizando 1080 frutos, que diferiram no momento de aplicação dos agentes. No primeiro, os agentes foram aplicados nos frutos e logo após a secagem foi efetuada a inoculação do patógeno (Protetor). No segundo experimento, foi efetuada a inoculação e logo após a secagem da gota do inóculo, efetuou-se a aplicação dos agentes (Erradicante). No terceiro, os frutos foram inoculados e $24 \mathrm{~h}$ depois tratados (Curativo). E no último experimento, os frutos foram tratados e após 48 h, inoculados com o patógeno (Indução de resistência). Nos dois últimos experimentos, os frutos, enquanto aguardavam a aplicação dos agentes ou do inóculo, permaneceram em câmara controlada $\left(23^{\circ} \mathrm{C}\right.$ a $85 \%$ UR), nas mesmas condições até o final dos testes.

Frutos de laranja Valência foram coletados na Fazenda Oriçanga, situada no município de Mogi-Guaçu (SP), sendo posteriormente lavados com água e submetidos a desinfestação superficial utilizando-se hipoclorito de sódio (200ppm). A inoculação nos frutos foi efetuada com o uso de discos de micélio do fungo. A partir de colônias do fungo com 7 dias, discos de micélio de $0,3 \mathrm{~cm}$ de diâmetro foram retirados das bordas das colônias e colocados no interior de orifícios no flavedo, sobre o albedo, em frutos de laranja (Figura 6). Os frutos foram tratados com as diferentes preparações via aspersão, em uma caixa plástica branca rasa $(80 \times 40 \times 15 \mathrm{~cm})$, e posteriormente, virados para

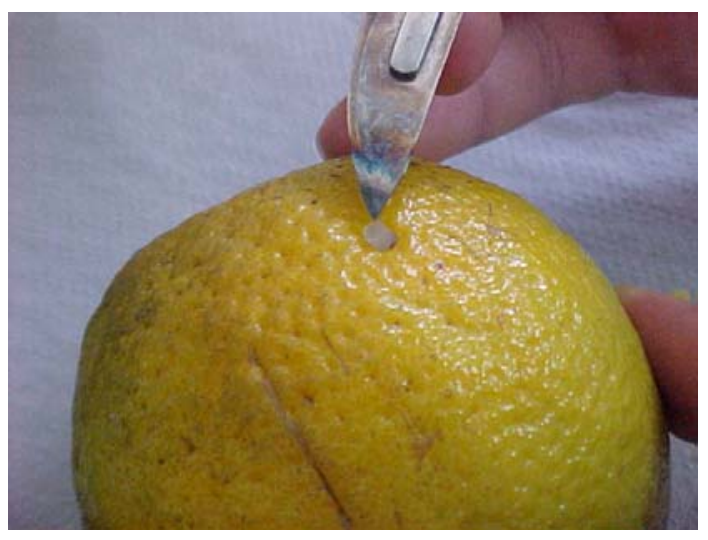

Figura 6 - Detalhe da inoculação realizada a partir de discos de micélio de Colletotrichum gloeosporioides no flavedo de frutos de laranja

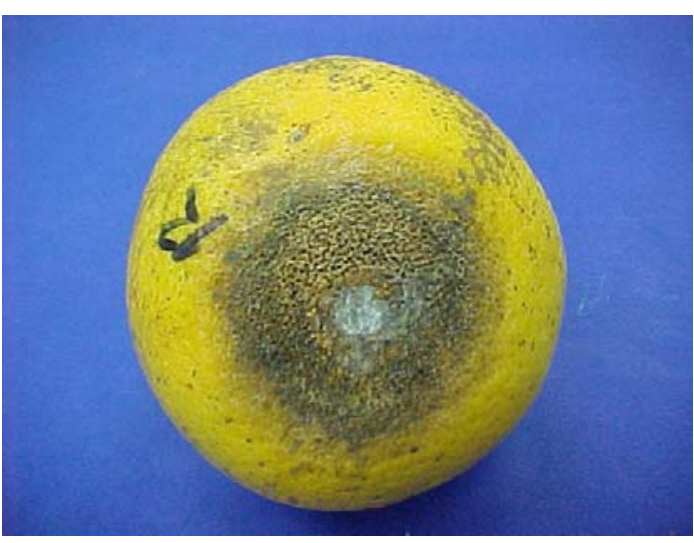

Figura 7 - Fruto de C. sinensis var. Valência, 15 dias após inoculação apresentando sintomas e esporulação (coloração salmão) de Colletotrichum gloeosporioides. Lesões oriundas de inoculação com disco de micélio

que toda a superfície dos frutos fosse tratada, tendo-se utilizado $100 \mathrm{~mL}$ de calda por tratamento (Figura 3). A seguir, os frutos foram mantidos em câmara controlada a $23^{\circ} \mathrm{C}$ e $85 \%$ UR por 15 dias. Neste período foram realizadas quatro avaliações $(7,9,12$ e 15 
dias após inoculação), sendo realizada a contagem do número de frutos doentes (com sintomas) e o diâmetro médio das lesões nos frutos doentes (Figura 7).

\subsection{Resultados e discussão}

\subsubsection{Influência do albedo e do flavedo no desenvolvimento in vitro de $G$. citricarpa, $P$. digitatum e C. gloeosporioides}

\subsubsection{Influência de compostos voláteis do albedo e flavedo}

Os resultados evidenciaram que nas placas que continham albedo de $C$. sinensis houve pequena redução no crescimento micelial de G. citricarpa, C. gloeosporioides e P. digitatum, sendo a redução maior sobre o fungo G. citricarpa (Figura 8). Por sua vez, o flavedo de C. aurantifolia var. Tahiti inibiu parcialmente o crescimento de G. citricarpa e C. gloeosporioides, onde também foi possível observar uma alteração na coloração da colônia. E por fim, houve um pequeno estímulo no crescimento do $P$. digitatum (Figura 9). Muitos patógenos ocorrem apenas no flavedo da laranja, pois no albedo podem existir substâncias de ação inibitória, podendo estas serem de origem volátil ou não. Alguns compostos de origem volátil, vale destacar, podem ser observados na inibição causada pelo albedo sobre G. citricarpa e do flavedo sobre C. gloeosporioides. Porém, alguns trabalhos demonstram que existem compostos inibitórios presentes no albedo e flavedo, porém não de origem volátil (CARDOSO FILHO, 2003; EL-TOBSHY; SINCLAIR, 1964). Muitas vezes estes compostos voláteis de ação inibitória não são observados quando em contato direto com o patógeno uma vez que nas metodologia de extração e preparo, estes compostos podem desaparecer, devido a sua condição volátil. Com base nos resultados obtidos, evidenciou-se que existem no albedo de laranja Valência, compostos voláteis fungitóxicos para os fungos estudados, principalmente para G. citricarpa, devendo-se no futuro procurar caracterizar os mesmos. 


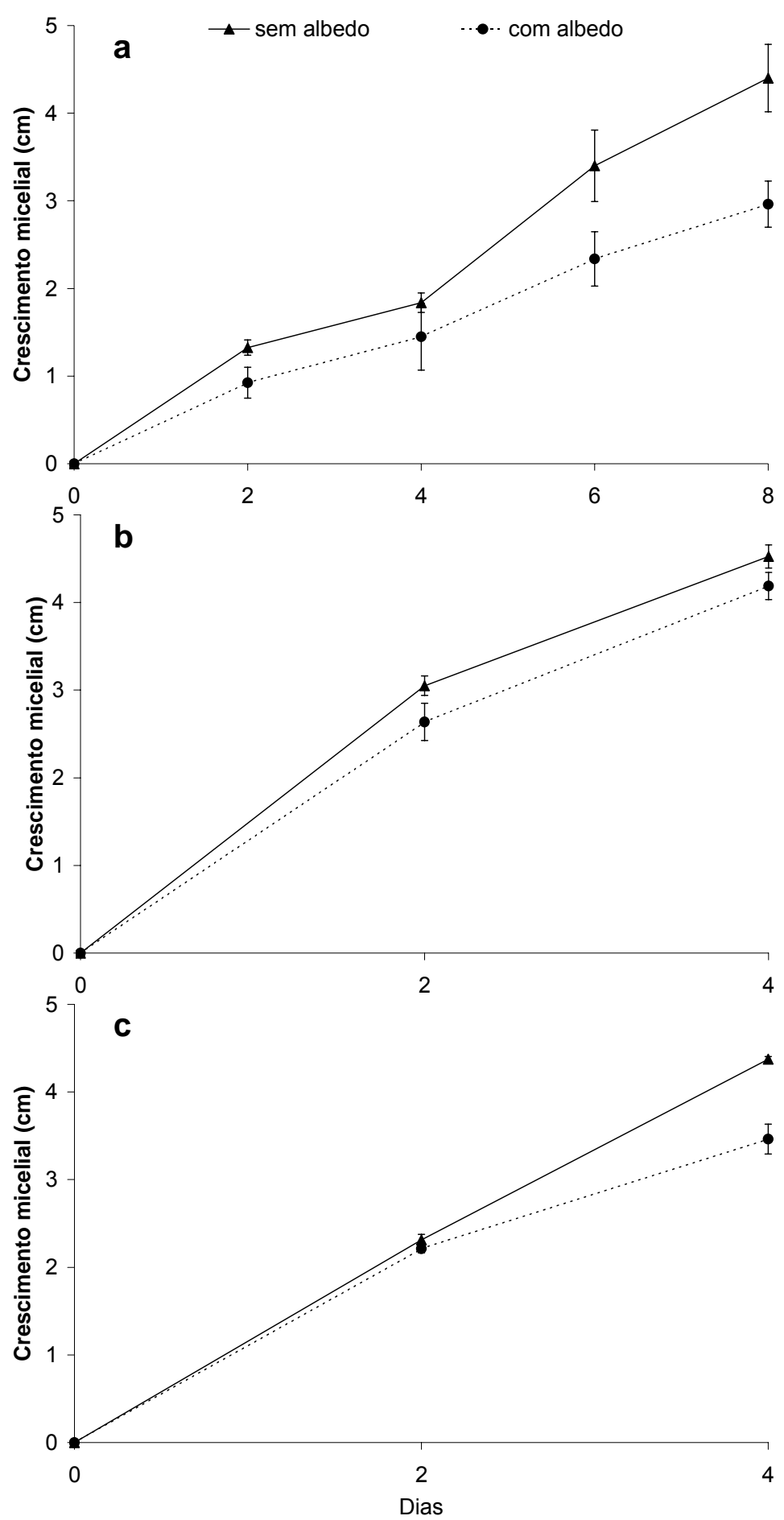

Figura 8 - Efeito dos compostos voláteis presentes no albedo de $C$. sinensis var. Valência sobre o crescimento micelial de: a) Guignardia citricarpa; b) Penicillium digitatum; c) Colletotrichum gloeosporioides. As barras representam a média \pm desvio padrão 

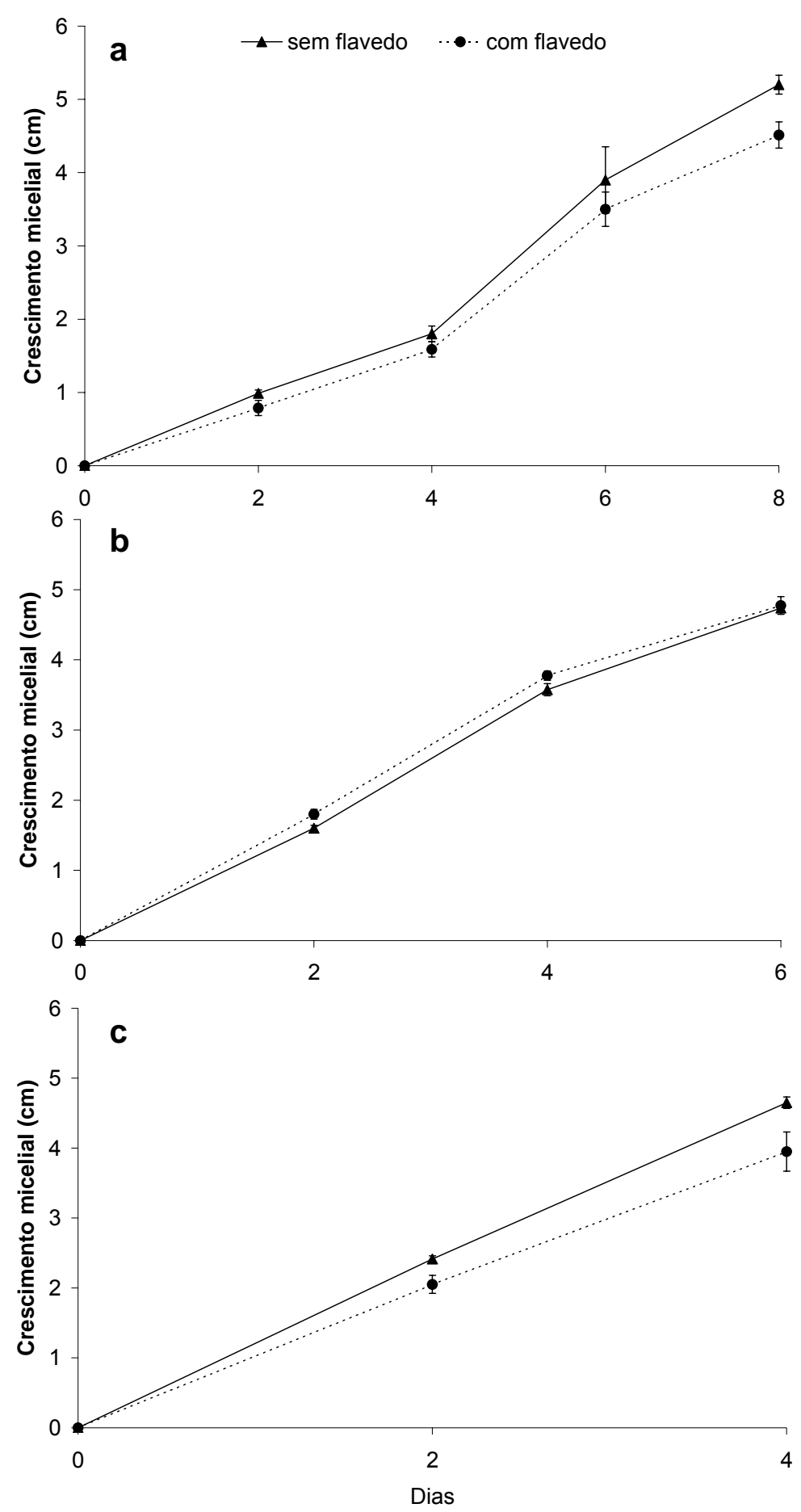

Figura 9 - Efeito dos compostos voláteis presentes no flavedo de C. aurantifolia var. Tahiti sobre o crescimento micelial de: a) Guignardia citricarpa; b) Penicillium digitatum; c) Colletotrichum gloeosporioides. As barras representam a média \pm desvio padrão 


\subsubsection{Influência dos extratos no crescimento micelial}

\subsection{Albedo - C. sinensis var. Valência}

Este extrato não demonstrou efeito inibitório sobre o crescimento micelial, germinação e formação de apressório por P. digitatum e C. gloeosporioides (Figuras 10, 11 e 12). Sendo que $P$. digitatum, na presença do extrato, apresentou maior crescimento micelial (Figura 10a) e germinação (Figura 11a) do que a testemunha $\left(\mathrm{H}_{2} \mathrm{O}\right)$, porém a formação de apressório diminuía em função do aumento da concentração do extrato (figura 11b), pois houve rápido crescimento do tubo germinativo. C gloeosporioides não apresentou diferença quanto ao crescimento micelial (Figura 12a), germinação (Figura 11a) e formação de apressório (Figura 11b) em relação a testemunha. Sobre G. citricarpa, houve acentuada inibição do crescimento micelial (Figura 13a), à medida que a concentração do extrato etanólico do albedo de $C$. sinensis aumentava. Quanto a germinação e formação de apressório, houve inibição de $100 \%$ na concentração de $10 \mathrm{mg} / \mathrm{mL}$ (Figura 11a). Em trabalhos realizados por Cardoso Filho (2003) foi possível observar que o extrato etanólico de $C$. sinensis, porém da variedade pêra, também apresentou inibição no crescimento micelial, germinação e formação de apressório pelo fungo G. citricarpa. Estes resultados sugerem que o fungo G. citricarpa, fica restrito somente ao flavedo, pois provavelmente existem compostos tóxicos que impedem a entrada do patógeno no albedo. A caracterização e identificação dos compostos, presentes no albedo, que exibem efeito fungitóxico, seria de grande valia, uma vez que o albedo, para as laranjas destinadas para indústrias, é um subproduto. Neste contexto, existe a possibilidade da elaboração de um produto fungitóxico a partir dos compostos ativos do albedo.

\subsection{Flavedo - C. aurantifolia var. Tahiti}

Este extrato não demonstrou efeito inibitório sobre o crescimento micelial, germinação e formação de apressório sobre G. citricarpa e $P$. digitatum (Figuras 10, 12 e 14). P. digitatum, na presença do extrato, apresentou maior crescimento micelial (Figura 10b) e germinação (Figura 14a) do que a testemunha $\left(\mathrm{H}_{2} \mathrm{O}\right)$, porém quanto a formação de apressórios, conforme havia o aumento da concentração do extrato, 
praticamente não havia formação de nenhuma estrutura, pois houve rápido crescimento do tubo germinativo. G. citricarpa não apresentou diferença em relação a testemunha (Figuras 13b e 14a,b). Sobre C. gloeosporioides houve alta inibição do crescimento micelial, sendo que a placa testemunha $\left(\mathrm{H}_{2} \mathrm{O}\right)$ quando realizada a última avaliação apresentava $9 \mathrm{~cm}$ de diâmetro radial, enquanto que a maior concentração (10 mg do extrato/ $\mathrm{mL} \mathrm{H}_{2} \mathrm{O}$ ) apresentou 1,77 cm (Figura 12b). Quanto a germinação e formação de apressórios, houve inibição de 100\% na concentração de $10 \mathrm{mg} / \mathrm{mL}$ (Figura 14a,b). De acordo com Kotzé (1981), a laranja azeda é um dos únicos híbridos que não é suscetível a G. citricarpa, e de acordo com Aguilar Vildoso et. al (2002) somente a laranjeira azeda e seus híbridos, bem como a limeira ácida "Tahiti" são relatadas como resistente. Por outro lado, foi constatada a presença do patógeno no flavedo de frutos de limão Tahiti, mas não houve a expressão dos sintomas (BALDASSARI, 2005). Com base nestas informações, esperava-se que o extrato etanólico do flavedo apresentasse alguma inibição sobre G. citricarpa, o que não aconteceu. Provavelmente, essa expressão de sintomas não ocorra por fatores genéticos, pois esta espécie é considerada resistente (KOTZÉ, 1981, 1996), ou insensibilidade (presença do patógeno, porém não existe ocorrência de sintomas). Também, não é possível descartar a possibilidade da não existência de compostos químicos agindo sobre o fungo, pois outros solventes, poderiam ser utilizados na extração. 

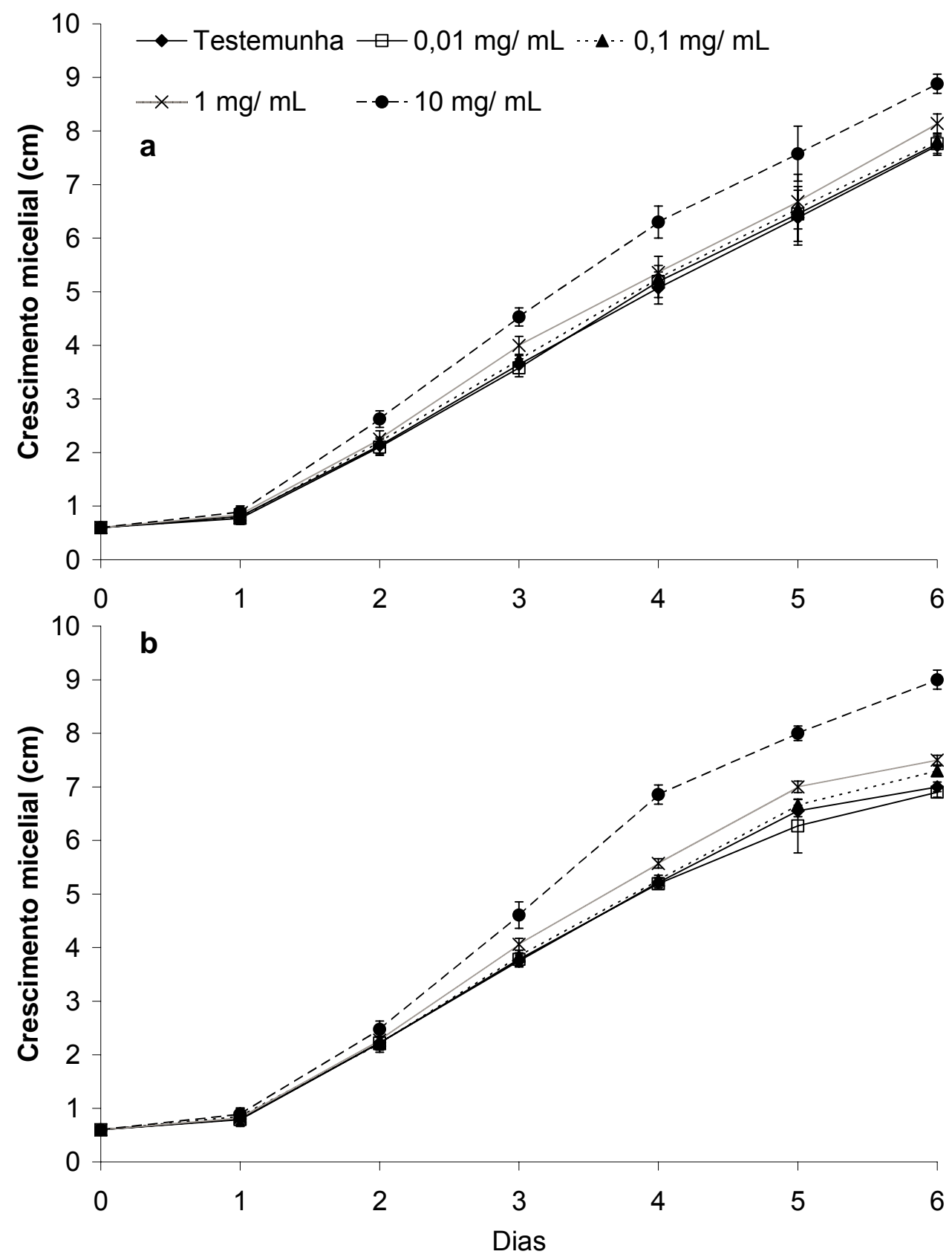

Figura 10 - Efeito do extrato etanólico do albedo de C. sinensis. var. Valência (a), e flavedo de C. aurantifolia var. Tahiti (b) no crescimento micelial de Penicillium digitatum. As barras representam a média \pm desvio padrão 

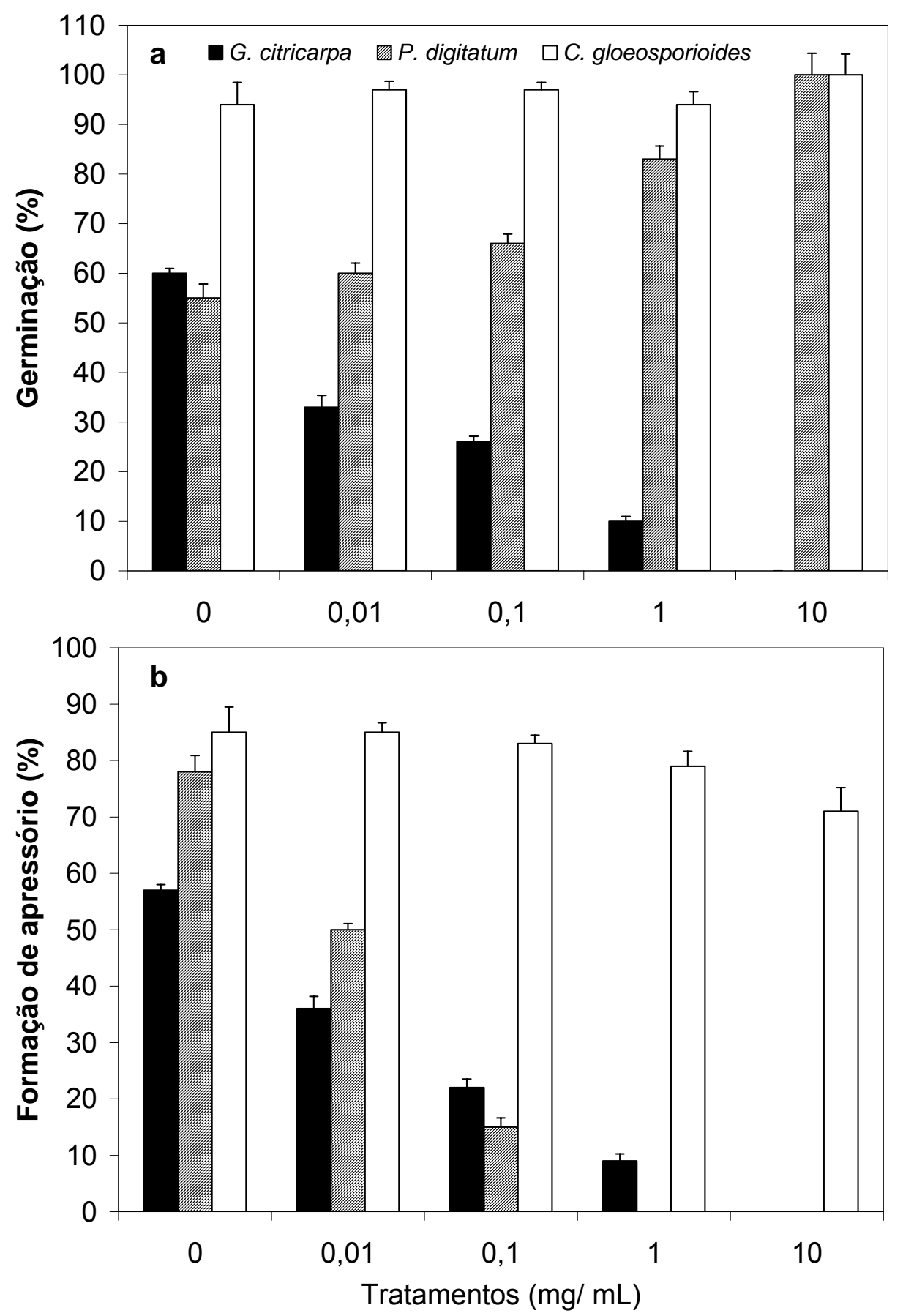

Figura 11 - Efeito do extrato etanólico do albedo de Citrus sinensis var. Valência na germinação (a) e formação de apressório (b) por Guignardia citricarpa, Penicillium digitatum e Colletotrichum gloeospoprioides. As barras representam a média \pm desvio padrão 

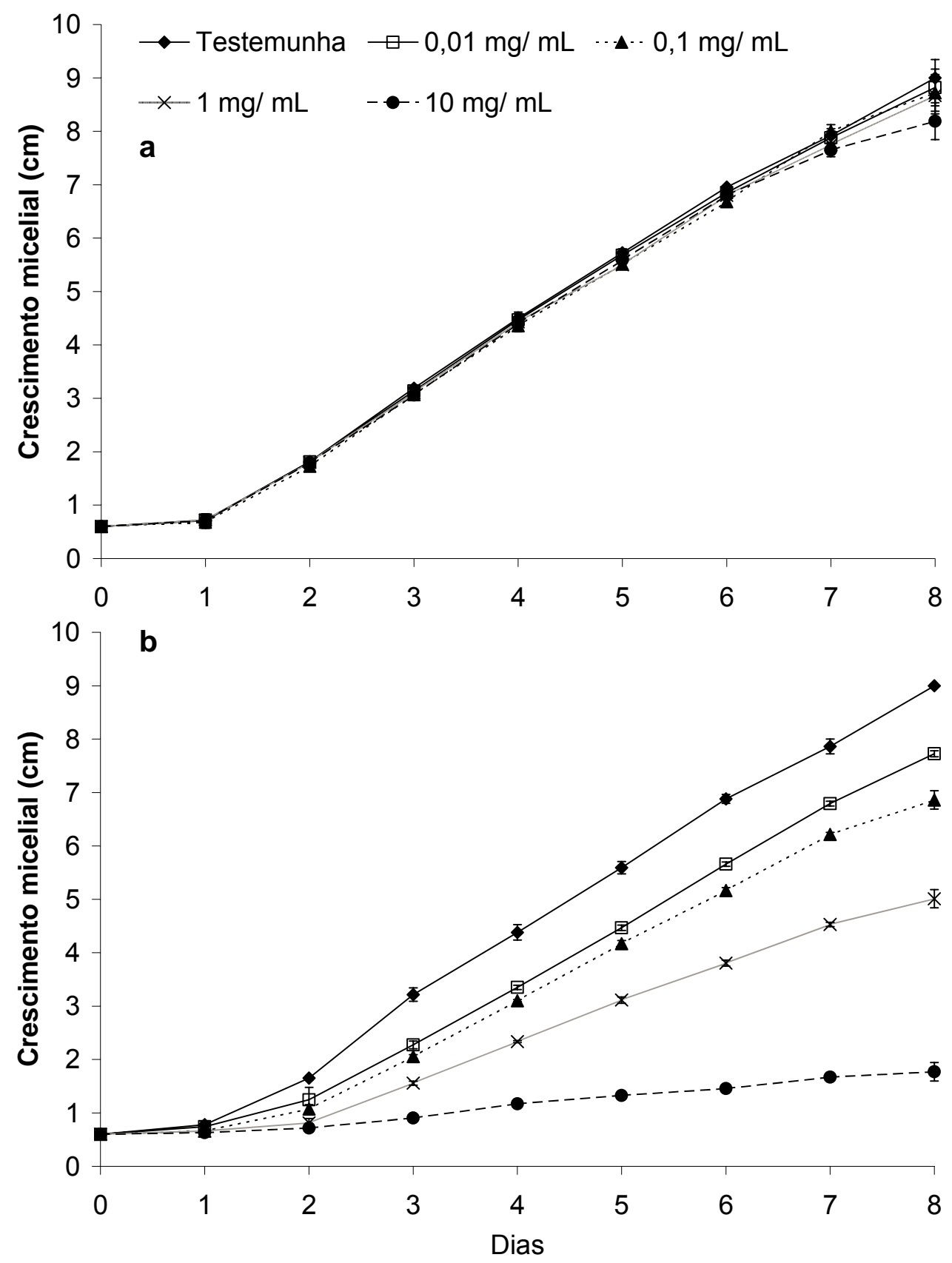

Figura 12 - Efeito do extrato etanólico do albedo de C. sinensis. var. Valência (a), e flavedo de C. aurantifolia var. Tahiti (b) no crescimento micelial de Colletotrichum gloeosporioides. As barras representam a média \pm desvio padrão 


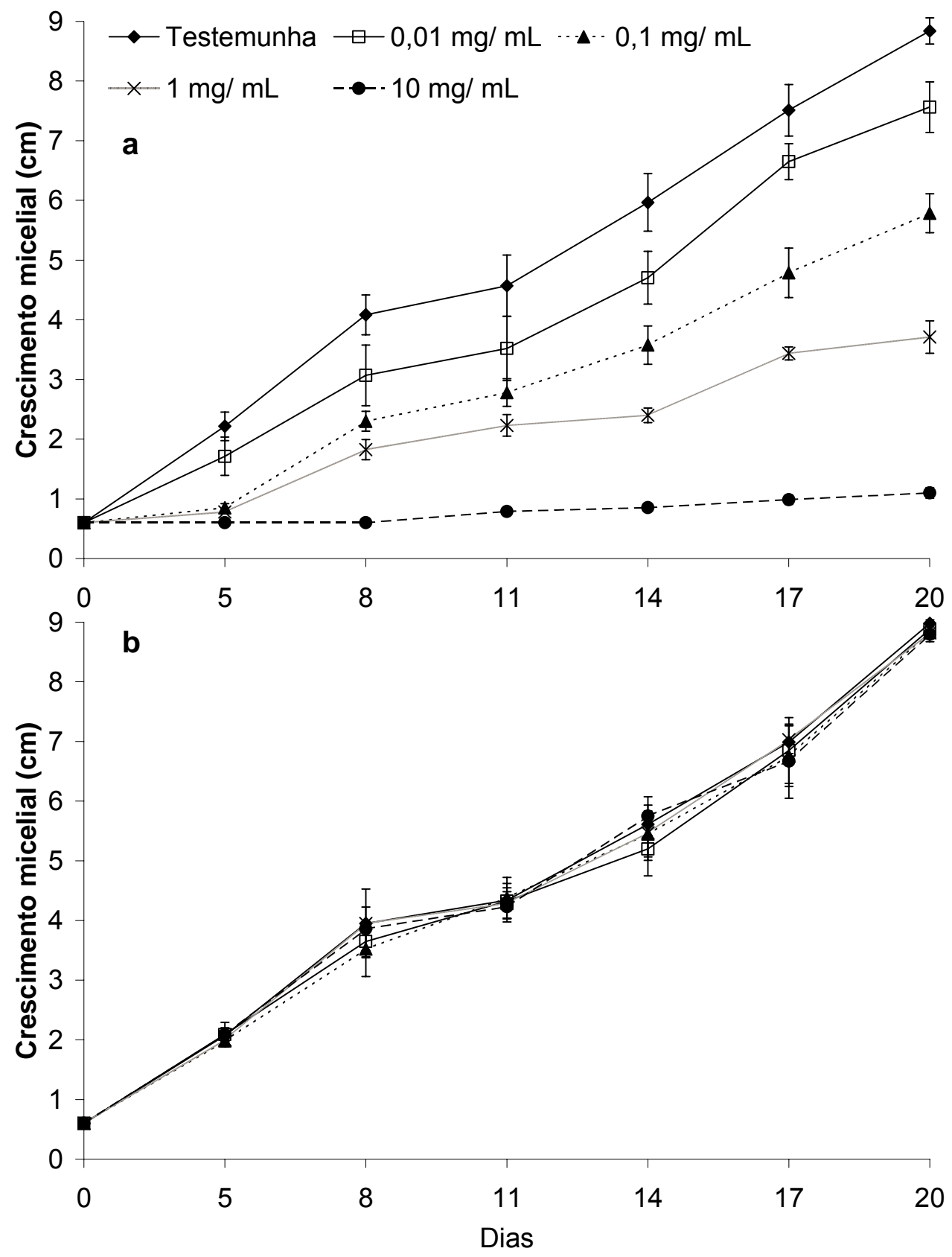

Figura 13 - Efeito do extrato etanólico do albedo de $C$. sinensis. var. Valência (a), e flavedo de C. aurantifolia var. Tahiti (b) no crescimento micelial de Guignardia citricarpa. As barras representam a média \pm desvio padrão 

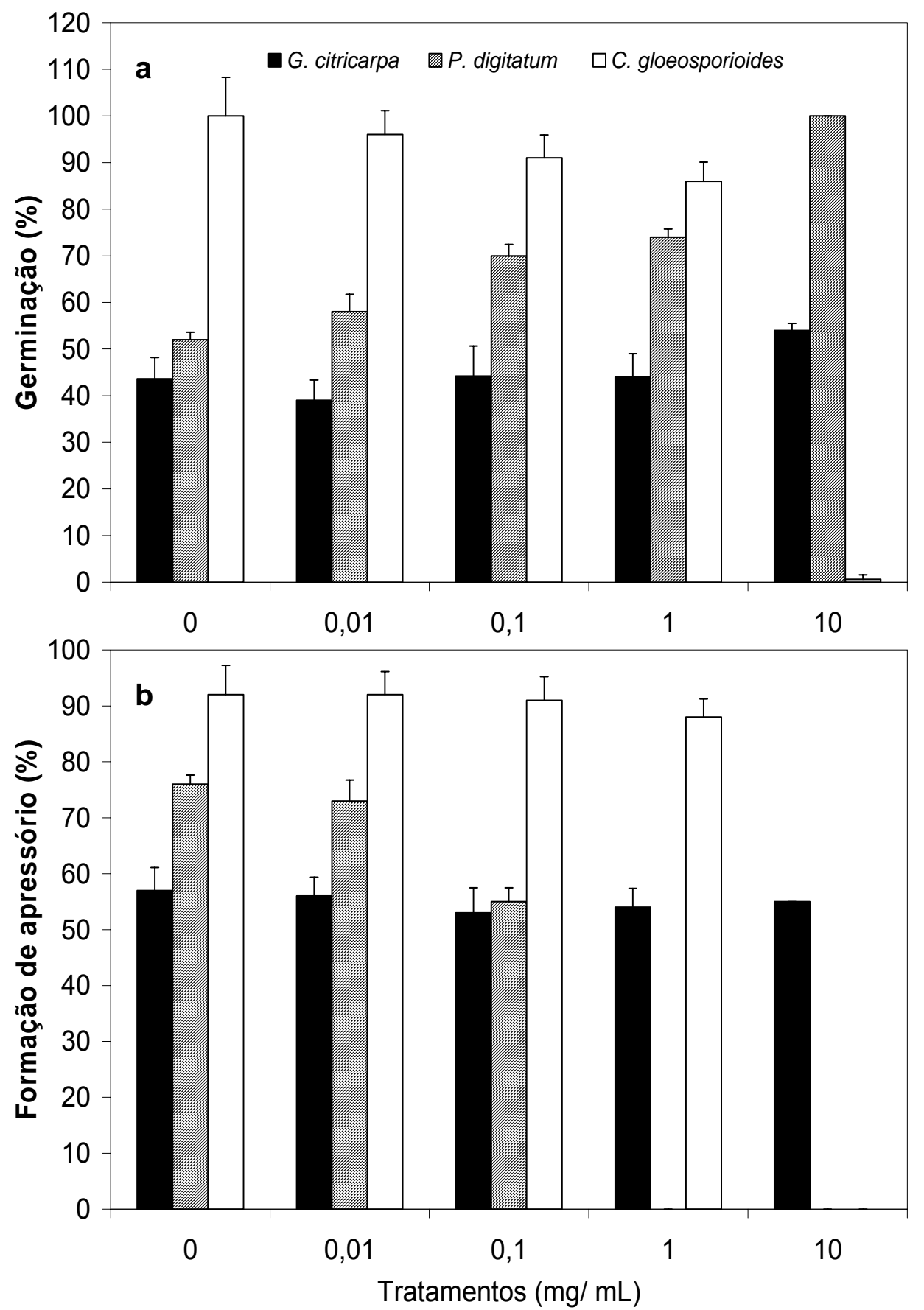

Figura 14 - Efeito do extrato etanólico do flavedo de Citrus aurantifolia var. Tahiti na germinação (a) e formação de apressório (b) de Guignardia citricarpa, Penicillium digitatum e Colletotrichum gloeospoprioides. As barras representam a média \pm desvio padrão 
2.4.2 Influência dos agentes bióticos e abiótico nas interações de $G$. citricarpa, $P$. digitatum e C. gloeosporioides com frutos de C. sinensis var. Valência

\subsubsection{Influência dos agentes bióticos e abiótico sobre a mancha preta dos citros}

O principal sintoma observado nos frutos em pós-colheita foi a lesão do tipo mancha sardenta, sendo estas lesões de coloração pardo-avermelhadas, pequenas, circulares que, normalmente, não exibem frutificações do fungo. Essas lesões originam-se de infecções latentes formadas nas fases de desenvolvimento dos frutos. Sua ocorrência dá-se principalmente quando os frutos encontram-se armazenados em ambiente de temperatura mais elevada. Do ponto de vista comercial, essas lesões constituem-se em problema de importância relevante quando o alvo desejado é principalmente o mercado externo, uma vez que as mesmas freqüentemente tornam-se mais evidentes alguns dias após a colheita, coincidindo com o tempo de chegada ao local de destino (FUNDECITRUS, 2004).

Com base nos resultados do primeiro experimento, é possível observar o número de lesões nos frutos em relação ao tempo e em cada tratamento (Figura 15). No quinto e nono dias de avaliação, não foi possível observar diferenças entre os tratamentos. Porém, a partir do décimo segundo dia até a última avaliação, foi possível observar que os quatro agentes bióticos (albedo, flavedo, L. edodes e A. blazei) inibiram o aparecimento de novas lesões nos frutos (Figura 15). Os resultados mostrados na Figura 16, relacionado ao último dia da avaliação (décimo quinto), evidenciam que os quatro agentes bióticos demonstraram maior inibição no aparecimento de novas lesões, quando comparados com a água, o Thiabendazole e o ácido jasmônico. Os tratamentos com o albedo de $C$. sinensis var. Valência e o cogumelo $A$. blazei proporcionaram os melhores resultados, quando comparados com os outros agentes, porém os mesmos não diferiram do L. edodes, o qual não diferiu do flavedo de C. aurantifolia var. Tahiti. 


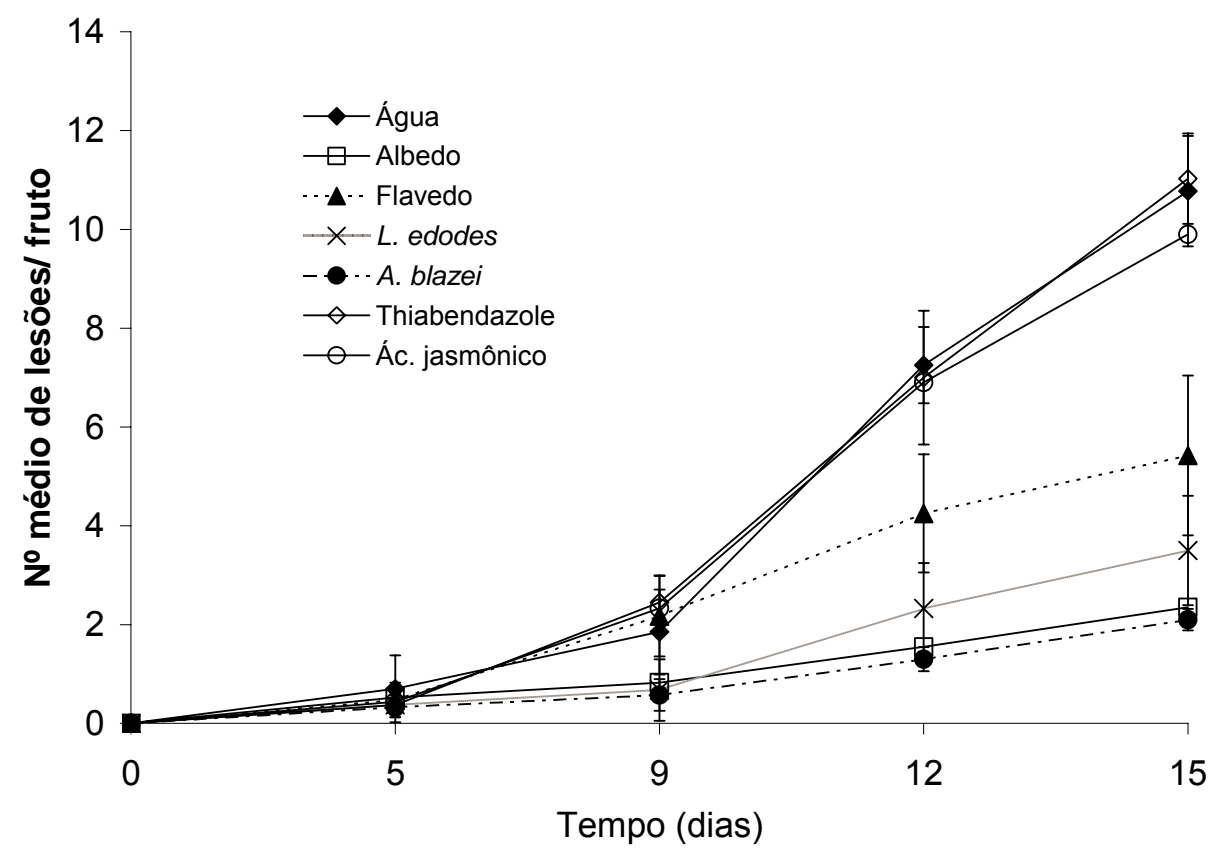

Figura 15 - Efeito dos extratos aquosos do albedo de $C$. sinensis var. Valência, flavedo de C. aurantifolia var. Tahiti, L. edodes e A. blazei, e do ácido jasmônico, aplicados em frutos de $C$. sinensis var. Valência, na expressão dos sintomas causados por $G$. citricarpa ( $1^{\circ}$ experimento). As barras representam a média \pm desvio padrão

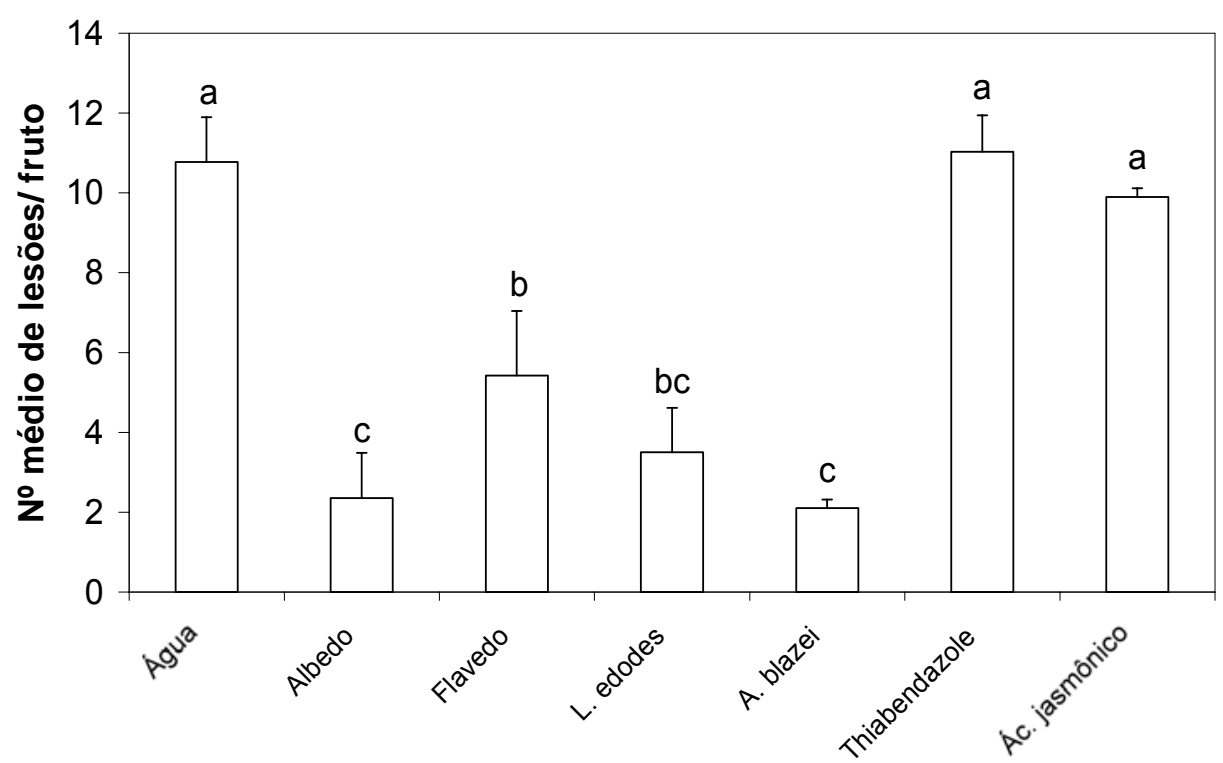

Tratamentos

Figura 16 - Efeito dos extratos aquosos do albedo de C. sinensis var. Valência, flavedo de C. aurantifolia var. Tahiti, L. edodes e A. blazei, e do ácido jasmônico, aplicados em frutos de $C$. sinensis var. Valência na expressão dos sintomas causados por $G$. citricarpa (1 ${ }^{\circ}$ Experimento). As barras representam a média \pm desvio padrão. Médias seguidas da mesma letra não diferem significativamente entre si (Tukey, $P=0,05$ ) 
Os resultados encontrados no segundo experimento, reproduzem parte do primeiro experimento (Figura 17). A partir do quinto dia de avaliação, foi possível observar uma redução no aparecimento de novas lesões por parte dos quatro agentes bióticos. Por sua vez, os resultados mostrados na Figura 18, relacionado ao último dia da avaliação (décimo quinto), evidencia que os quatro agentes também demonstraram maior inibição no aparecimento de novas lesões, quando comparados com a água e com o Thiabendazole. Porém, os agentes bióticos não apresentaram diferenças significativas entre si.

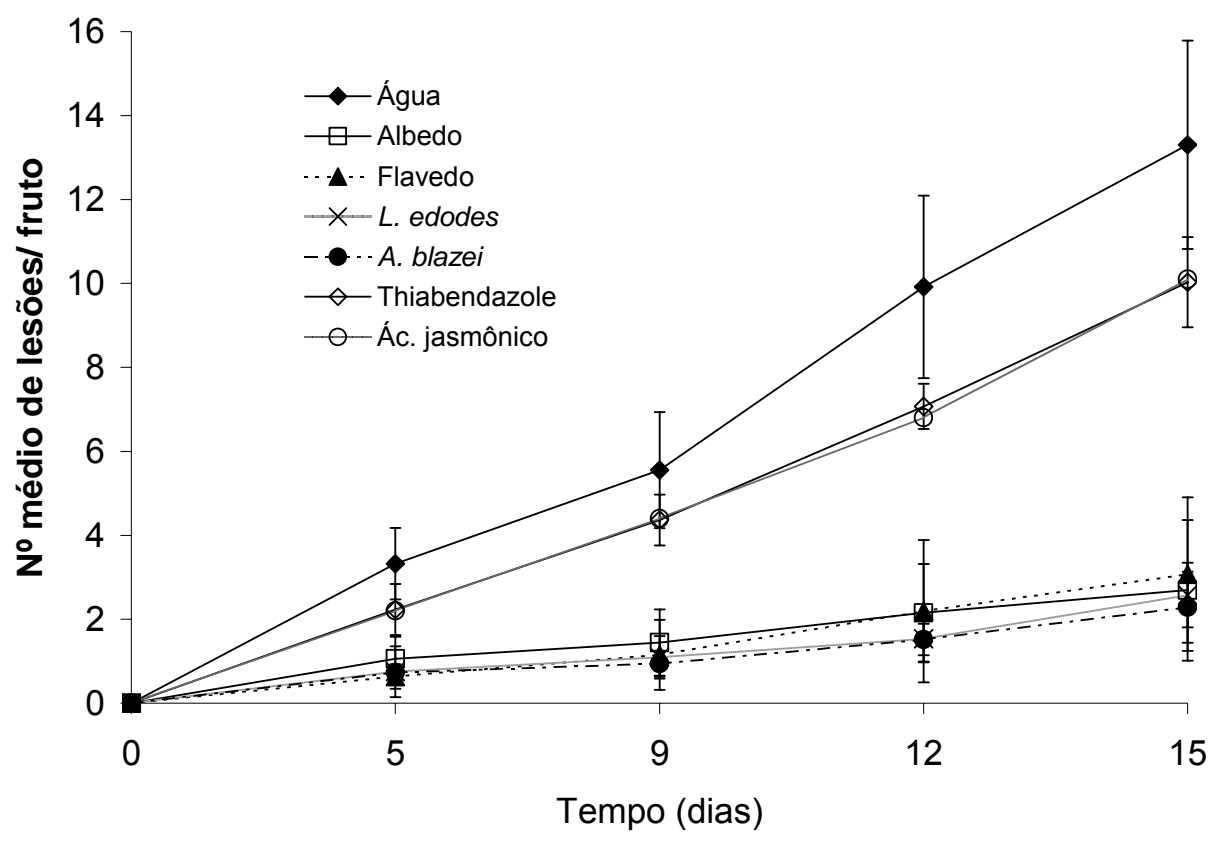

Figura 17 - Efeito dos extratos aquosos do albedo de C. sinensis var. Valência, flavedo de C. aurantifolia var. Tahiti, L. edodes e A. blazei, e do ácido jasmônico, aplicados em frutos de C. sinensis var. Valência, na expressão dos sintomas causados por $G$. citricarpa ( $2^{\circ}$ experimento). As barras representam a média \pm desvio padrão 


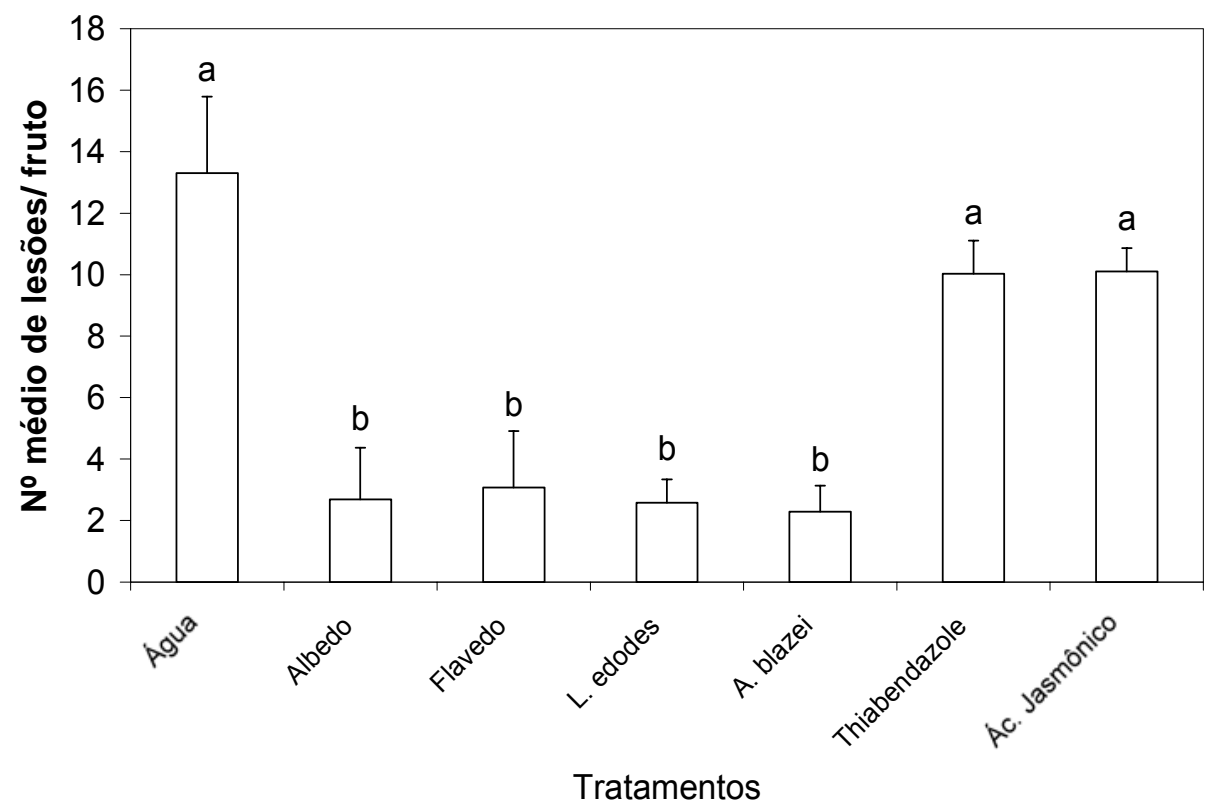

Figura 18 - Efeito dos extratos aquosos do albedo de C. sinensis var. Valência, flavedo de C. aurantifolia var. Tahiti, $L$. edodes e A. blazei, e do ácido jasmônico, aplicados em frutos de $C$. sinensis var. Valência, na expressão dos sintomas causados por G. citricarpa. As barras representam a média \pm desvio padrão. Médias seguidas da mesma letra não diferem significativamente entre si (Tukey, $\mathrm{P}=0,05$ )

A literatura mostra inúmeros trabalhos, onde frutos cítricos, em pós-colheita, têm mecanismos de resistência ativados, como as fitoalexinas (escoparona e escopoletina), em resposta a diferentes tipos de indutores bióticos e abióticos (ARRAS, 1996; RODOV et al., 1994; ALI; LEPOIVRE; SEMAL, 1991), levando a uma redução nos sintomas das doenças. Contudo, nesses trabalhos, os frutos foram tratados primeiramente com os indutores e inoculados com os patógenos logo a seguir, metodologia que difere da empregada neste ensaio. Dessa maneira, não se pode afirmar se houve indução de resistência nos frutos ou se ação direta dos agentes sobre o patógeno. Porém, trabalhos realizados in vitro por Cardoso Filho (2003) e trabalhos realizados neste projeto, onde utilizou-se o extrato etanólico do albedo de $C$. sinensis, demonstraram inibição do crescimento micelial, germinação e formação de apressório por G. citricarpa, indicando que provavelmente ocorreu ação direta do extrato do albedo sobre o patógeno. Quanto aos extratos dos cogumelos, existem trabalhos, porém realizados em plantas como fumo, pepino e maracujá, (PICCININ, 2000; DI PIERO; PASCHOLATI 
2001) onde demonstrou-se aumento de proteínas relacionadas a patogênese (ß-1,3glucanase, quitinase e peroxidase) quando as foram plantas tratadas. Assim, os extratos aquosos de $A$. blazei e $L$. edodes poderiam ter ativado mecanismos de defesas nos frutos de laranja. Por sua vez, o ácido jasmônico não apresentou efeito sobre o patógeno, e possivelmente, não ativou nenhum mecanismo de defesa nos frutos. Finalmente, em face dos resultados destes experimentos, os agentes bióticos estudados, mostram-se promissores no controle da mancha preta dos citros, quando aplicados em pós-colheita.

\subsubsection{Influência dos agentes bióticos e abiótico sobre o bolor verde dos citros}

\subsubsection{1 - Efeito "protetor"}

Após os frutos terem sido tratados e logo apos sofrido inoculação, os resultados na Figura 19, mostram que todos os agentes utilizados não inibiram o aparecimento da doença em frutos de $C$. sinensis var. Valência quando comparados com a água. $O$ aparecimento da doença começou três dias após a inoculação do fungo $P$. digitatum (Figura 19a), ocorrendo o aumento do número de frutos doentes a cada dia de avaliação em todos os tratamentos. Fica evidente que os frutos começaram a apresentar sinais do patógeno (esporulação) um dia após o início do surgimento da doença, ou seja, a partir do quarto dia após a inoculação (Figura 19b). Porém é possível observar que o flavedo do limão "Tahiti" reduziu o número de frutos doentes e a esporulação. Por sua vez, o ácido jasmônico e o albedo de $C$. sinensis var. Valência foram os tratamentos que mais estimularam o aparecimento de sintomas e a esporulação do patógeno. Na Figura 20, referente ao último dia de avaliação, não ocorreram diferenças significativas entre os tratamentos, e todos os frutos que ficaram doentes, apresentaram esporulação do patógeno. Ocorrendo o mesmo em todos os tratamentos. 

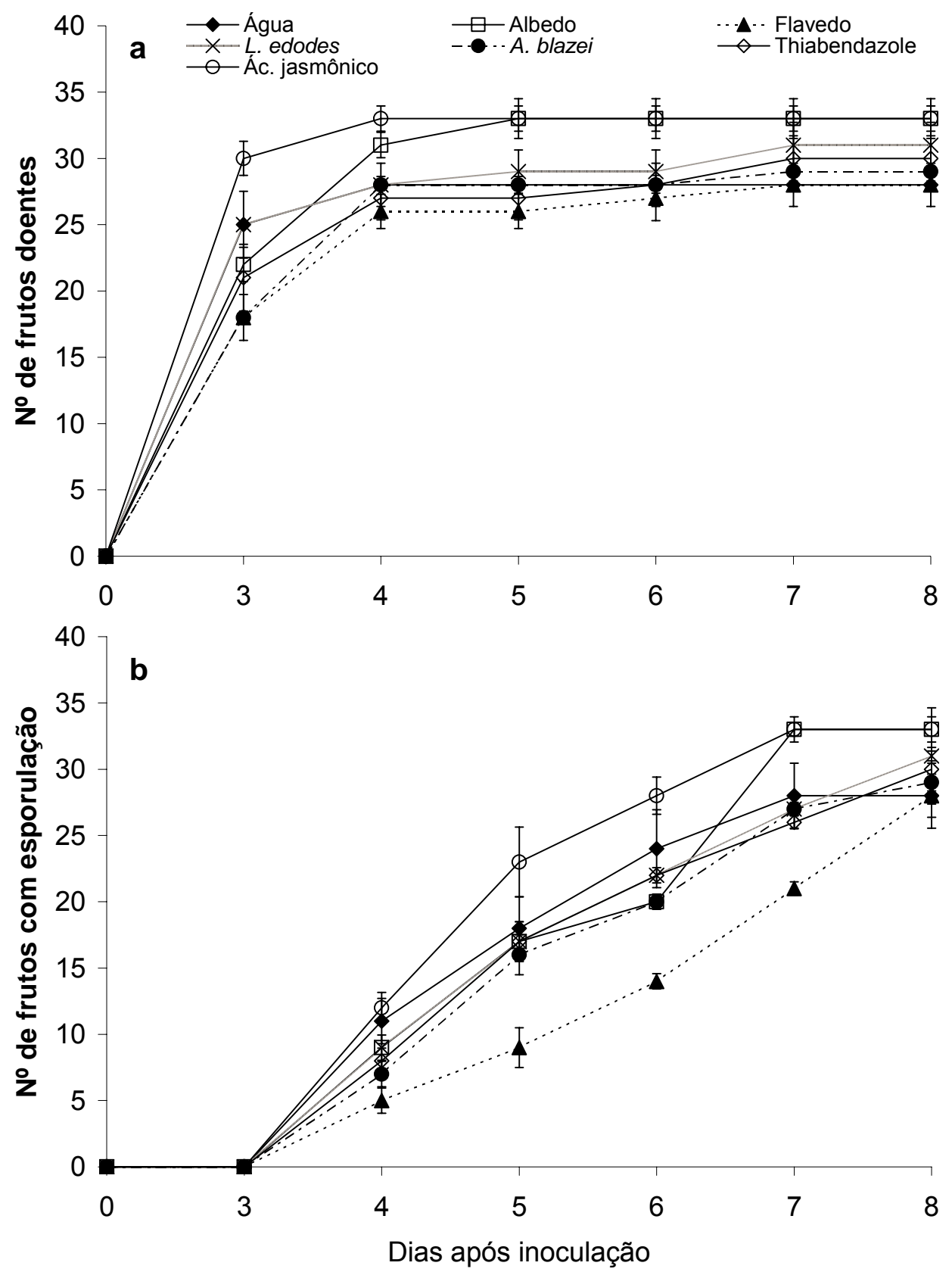

Figura 19 - Efeito protetor dos extratos aquosos do albedo de $C$. sinensis var. Valência, flavedo de C. aurantifolia var. Tahiti, $L$. edodes, A. blazei e do ácido jasmônico, aplicados em frutos de $C$. sinensis var. Valência no controle de $P$. digitatum. As barras representam a média \pm desvio padrão 


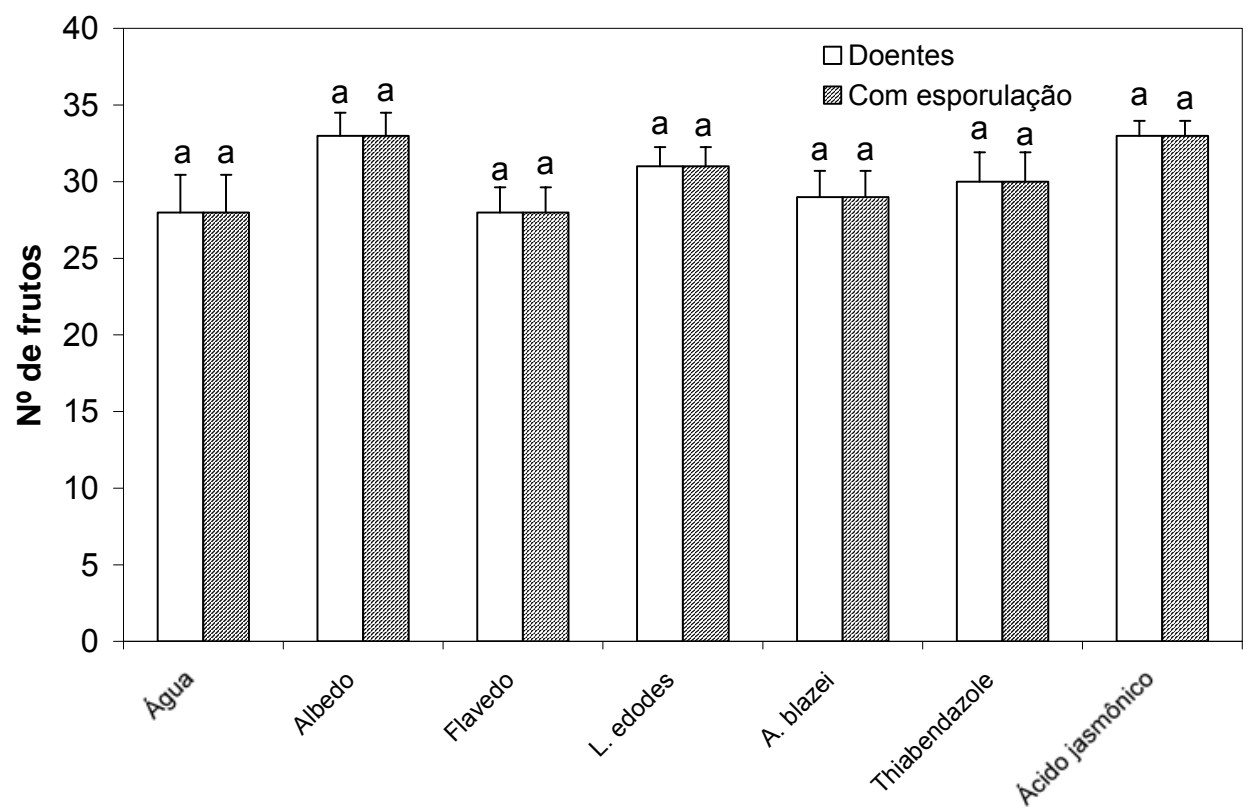

Tratamentos

Figura 20 - Efeito protetor dos extratos aquosos do albedo de $C$. sinensis var. Valência, flavedo de C. aurantifolia var. Tahiti, L. edodes, A. blazei e do ácido jasmônico, aplicados em frutos de $C$. sinensis var. Valência no controle de $P$. digitatum. As barras representam a média \pm desvio padrão. Médias seguidas da mesma letra não diferem significativamente entre si (Tukey $\mathrm{P}=$ $0,05)$

\subsubsection{2 - Efeito "erradicante"}

Após os frutos terem sido inoculados e logo apos tratados, todos os agentes utilizados apresentaram baixa inibição no aparecimento de frutos doentes e no número de frutos que apresentaram esporulação do patógeno. Os resultados da Figura 21 evidenciam que todos os agentes utilizados não inibiram o aparecimento da doença em frutos de $C$. sinensis var. Valência quando comparados com a água. $O$ aparecimento dos sintomas começou três dias após a inoculação do fungo $P$. digitatum (Figura 21a), ocorrendo um aumento do número de frutos doentes a cada dia de avaliação em todos os tratamentos. Fica evidenciado que os frutos começaram a apresentar sinais do patógeno (esporulação) um dia após o início do surgimento da doença (Figura 21b), ou seja, a partir do quarto dia após a inoculação. Porém, é possível observar que o flavedo do limão "Tahiti" reduziu o número de frutos doentes e de frutos com esporulação. Por sua vez, os extratos do albedo de $C$. sinensis var. Valência e do A. blazei, estimularam o aparecimento da doença e a esporulação do patógeno. Na Figura 22, referente ao 
último dia de avaliação, não se observam diferenças entre os tratamentos, e todos os frutos que exibiam sintomas, apresentaram esporulação do patógeno.
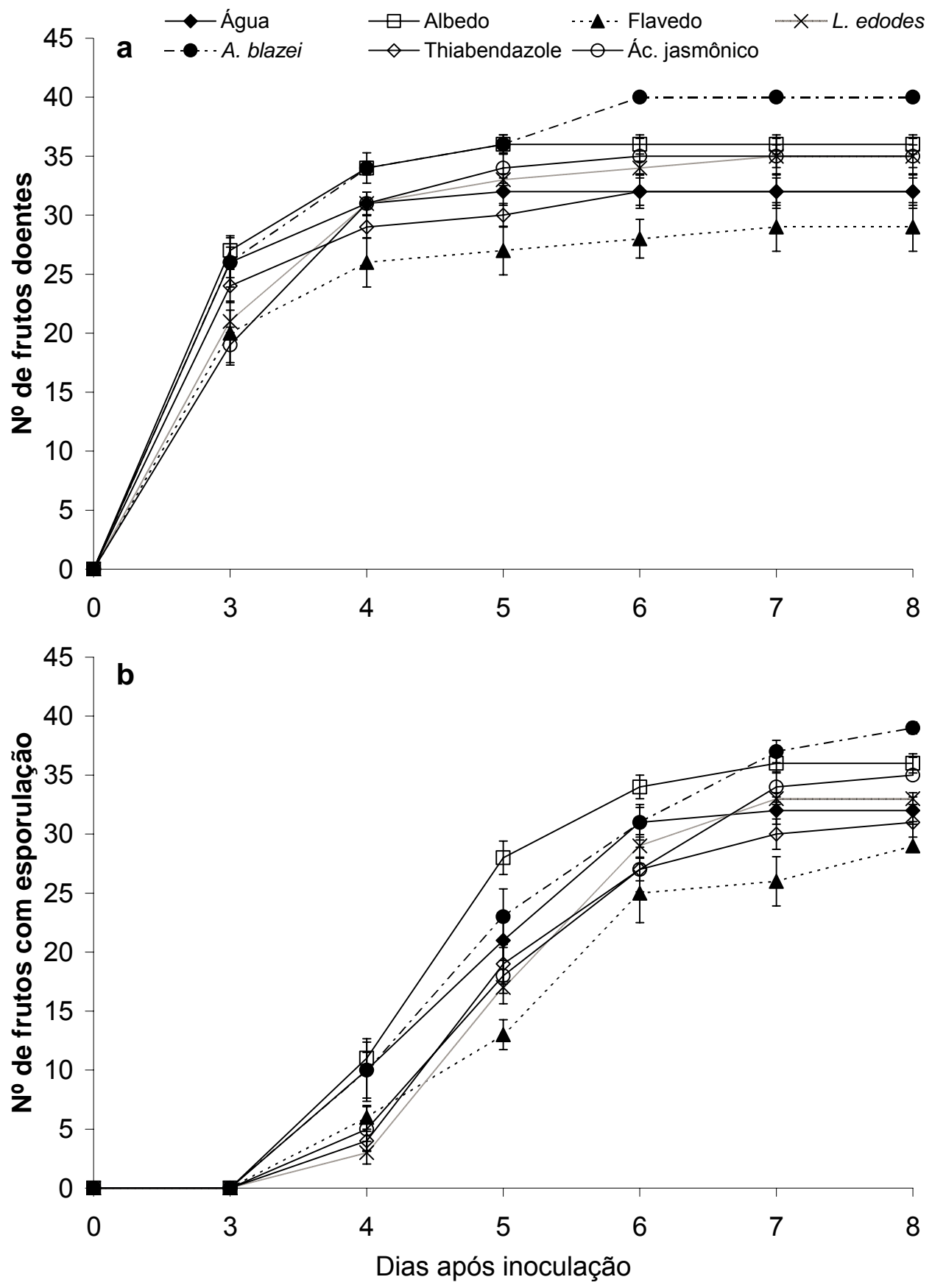

Figura 21 - Efeito erradicante dos extratos aquosos do albedo de $C$. sinensis var. Valência, flavedo de $C$. aurantifolia var. Tahiti, L. edodes, $A$. blazei e do ácido jasmônico, aplicados em frutos de $C$. sinensis var. Valência no controle de $P$. digitatum. As barras representam a média \pm desvio padrão 


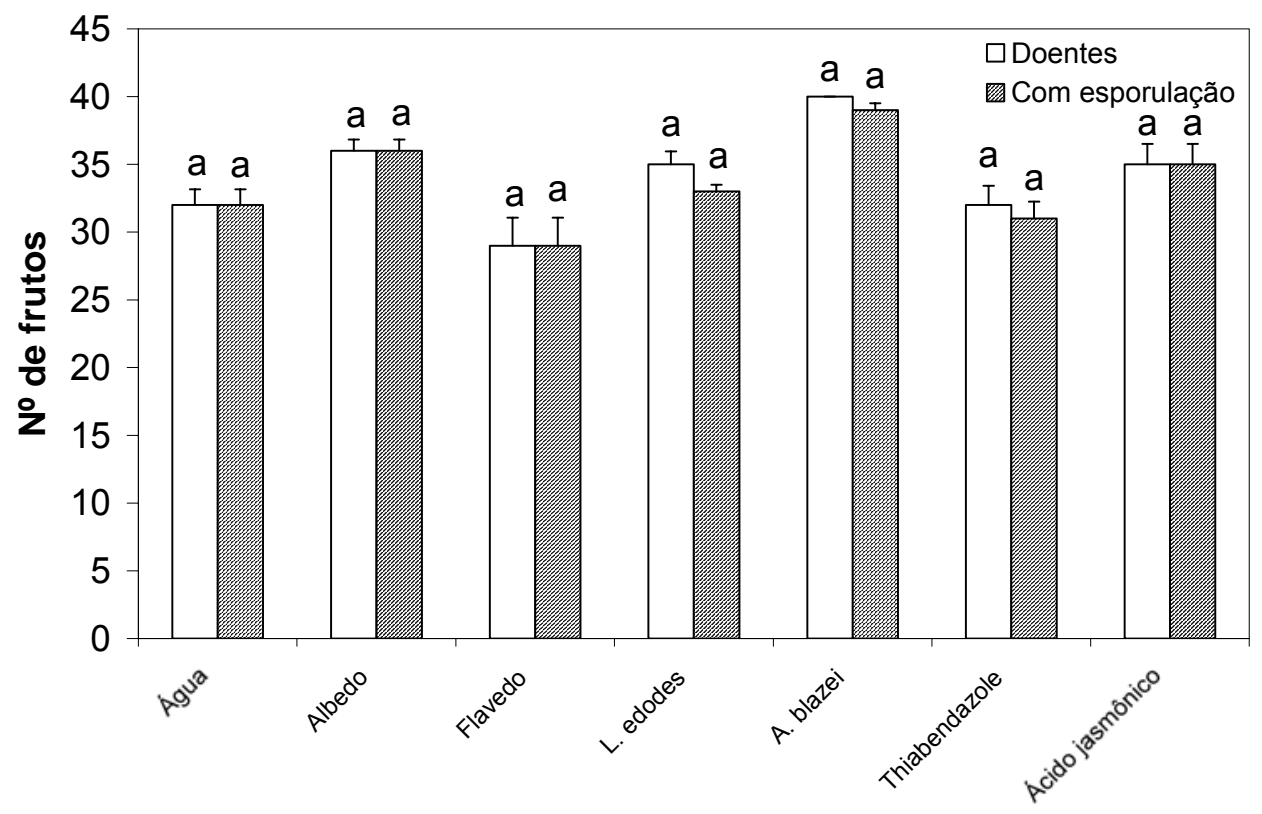

Tratamentos

Figura 22 - Efeito erradicante dos extratos aquosos do albedo de $C$. sinensis var. Valência, flavedo de C. aurantifolia var. Tahiti, L. edodes, A. blazei e do ácido jasmônico, aplicados em frutos de $C$. sinensis var. Valência no controle de $P$. digitatum. As barras representam a média \pm desvio padrão. Médias seguidas da mesma letra não diferem significativamente entre si (Tukey $P=0,05$ )

\subsubsection{3 - Efeito "curativo"}

Após os frutos terem sido tratados e $24 \mathrm{~h}$ depois inoculados, os resultados deste experimento foram semelhantes ao do "Erradicante" (item 2.4.2.2.2) (Figura 23). Todos os agentes utilizados apresentaram baixa inibição no aparecimento de frutos doentes e no número de frutos que apresentaram esporulação do patógeno, com exceção do flavedo do limão "Tahiti". O aparecimento da doença começou três dias após a inoculação do fungo Penicillium digitatum (Figura 23a), ocorrendo o aumento do número de frutos doentes a cada dia de avaliação em todos os tratamentos. Fica bem caracterizado que os frutos começaram a apresentar sinais do patógeno (esporulação) um dia após o início do surgimento da doença (Figura 23b), ou seja, a partir do quarto dia após a inoculação. Porém, é possível observar que o flavedo do "Tahiti" também manteve-se abaixo da testemunha (água), tanto no gráfico de frutos doentes quanto no gráfico de frutos com esporulação. Os extratos do albedo de $C$. sinensis var. Valência e 
do A. blazei, estimularam o aparecimento da doença e esporulação do patógeno (Figura 23). Na Figura 24, referente ao último dia de avaliação, o extrato do flavedo do "Tahiti" apresentou diferença em relação aos tratamentos com albedo de $C$. sinensis var. Valência e $A$. blazei, quando observados o número de frutos doentes e com esporulação, caracterizando uma inibição por parte do flavedo. Porém, não houve diferença estatística em relação a água, mas os resultados de número de frutos doentes e esporulação foram inferiores no flavedo. Este resultado não condiz com os resultados apresentados in vitro, visto que o extrato etanólico de $C$. auratifolia var. Tahiti, quando colocado em contato com o fungo $P$. digitatum, estimulou o crescimento do mesmo. 


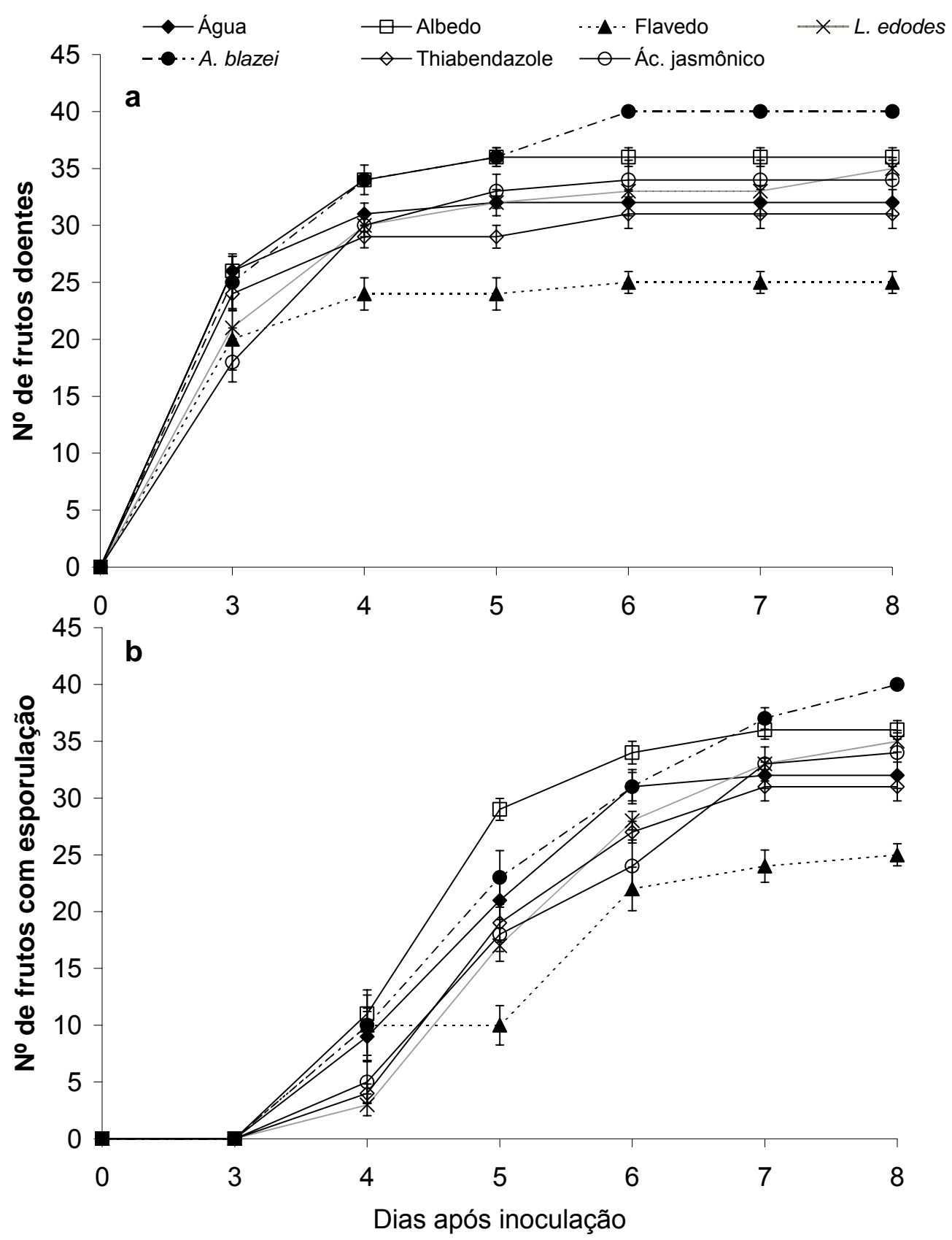

Figura 23 - Efeito curativo dos extratos aquosos do albedo de $C$. sinensis var. Valência, flavedo de C. aurantifolia var. Tahiti, $L$. edodes, A. blazei e do ácido jasmônico, aplicados em frutos de $C$. sinensis var. Valência no controle de $P$. digitatum. As barras representam a média \pm desvio padrão 


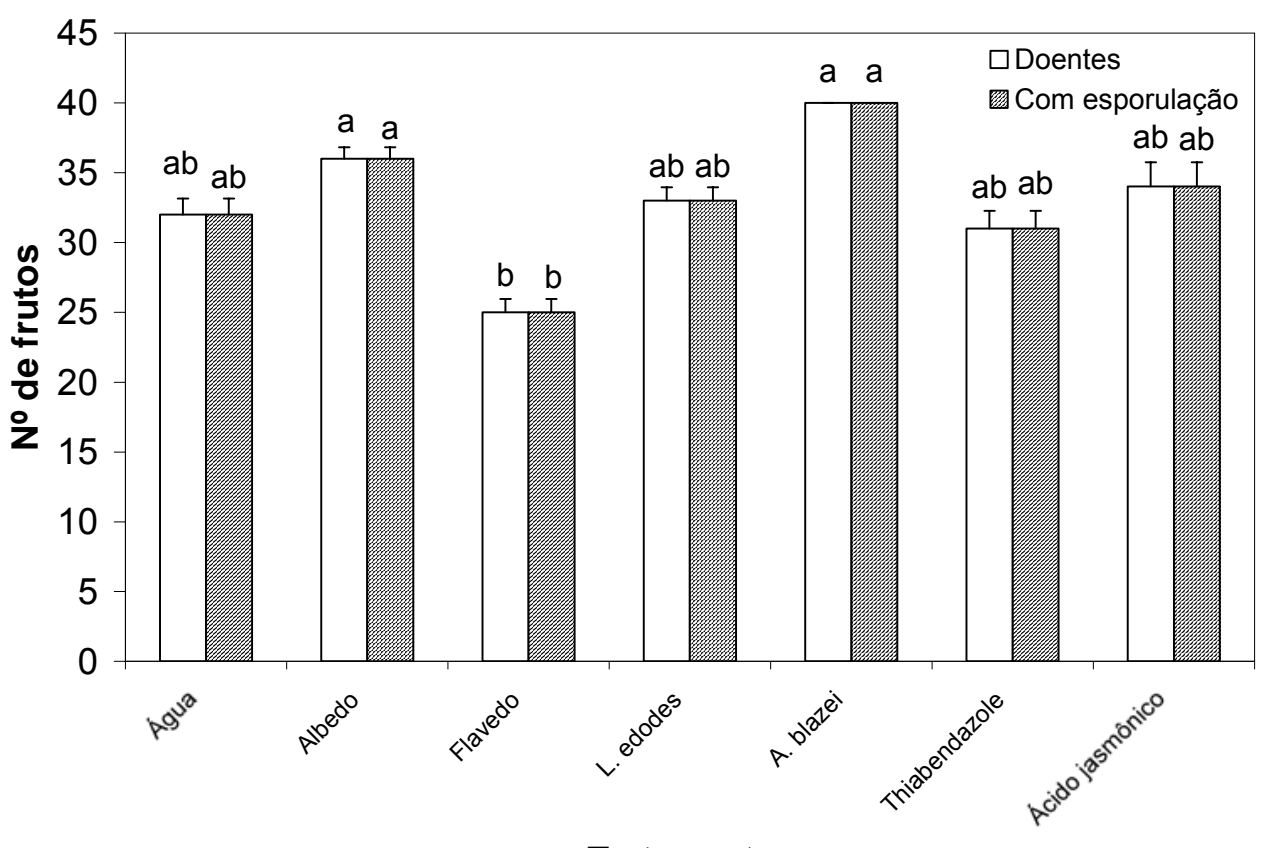

Tratamentos

Figura 24 - Efeito curativo dos extratos aquosos do albedo de C. sinensis var. Valência, flavedo de C. aurantifolia var. Tahiti, L. edodes, A. blazei e do ácido jasmônico, aplicados em frutos de C. sinensis var. Valência no controle de $P$. digitatum. As barras representam a média \pm desvio padrão. Médias seguidas da mesma letra não diferem significativamente entre si (Tukey $P=0,05$ )

\subsubsection{4 - Efeito "indutor de resistência"}

Após os frutos terem sido tratados e $48 \mathrm{~h}$ depois inoculados, os resultados da Figura 25 mostram que todos os agentes utilizados não inibiram o aparecimento da doença em frutos de $C$. sinensis var. Valência quando comparados com a água. $O$ aparecimento da doença começou três dias após a inoculação do Penicillium digitatum (Figura 25a), ocorrendo o aumento do número de frutos doentes a cada dia de avaliação em todos os tratamentos. Fica caracterizado que os frutos começaram a apresentar sinais do patógeno (esporulação) um dia após o início do surgimento da doença (Figura 25b), ou seja, a partir do quarto dia após a inoculação. Ao contrário dos outros experimentos, nenhum tratamento apresentou diferença quanto ao número de frutos doentes e frutos que apresentaram esporulação do patógeno. Na Figura 26, referente ao último dia de avaliação, não houve diferença entre nenhum tratamento, e todos os frutos que ficaram doentes, apresentaram esporulação do patógeno. 


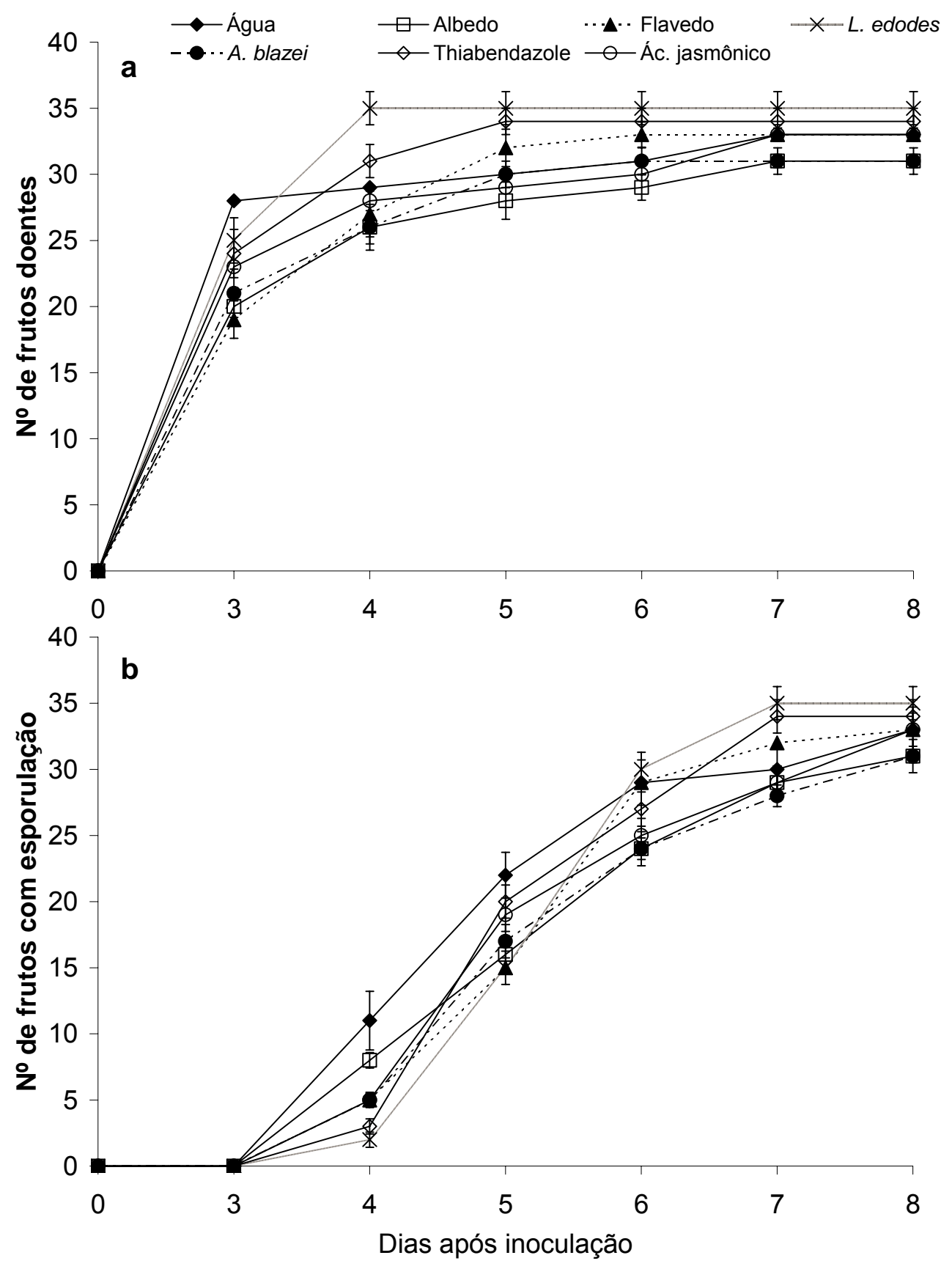

Figura 25 - Efeito indutor de resistência dos extratos aquosos do albedo de C. sinensis var. Valência, flavedo de C. aurantifolia var. Tahiti, $L$. edodes, $A$. blazei e do ácido jasmônico, aplicados em frutos de $C$. sinensis var. Valência no controle de $P$. digitatum. As barras representam a média \pm desvio padrão 


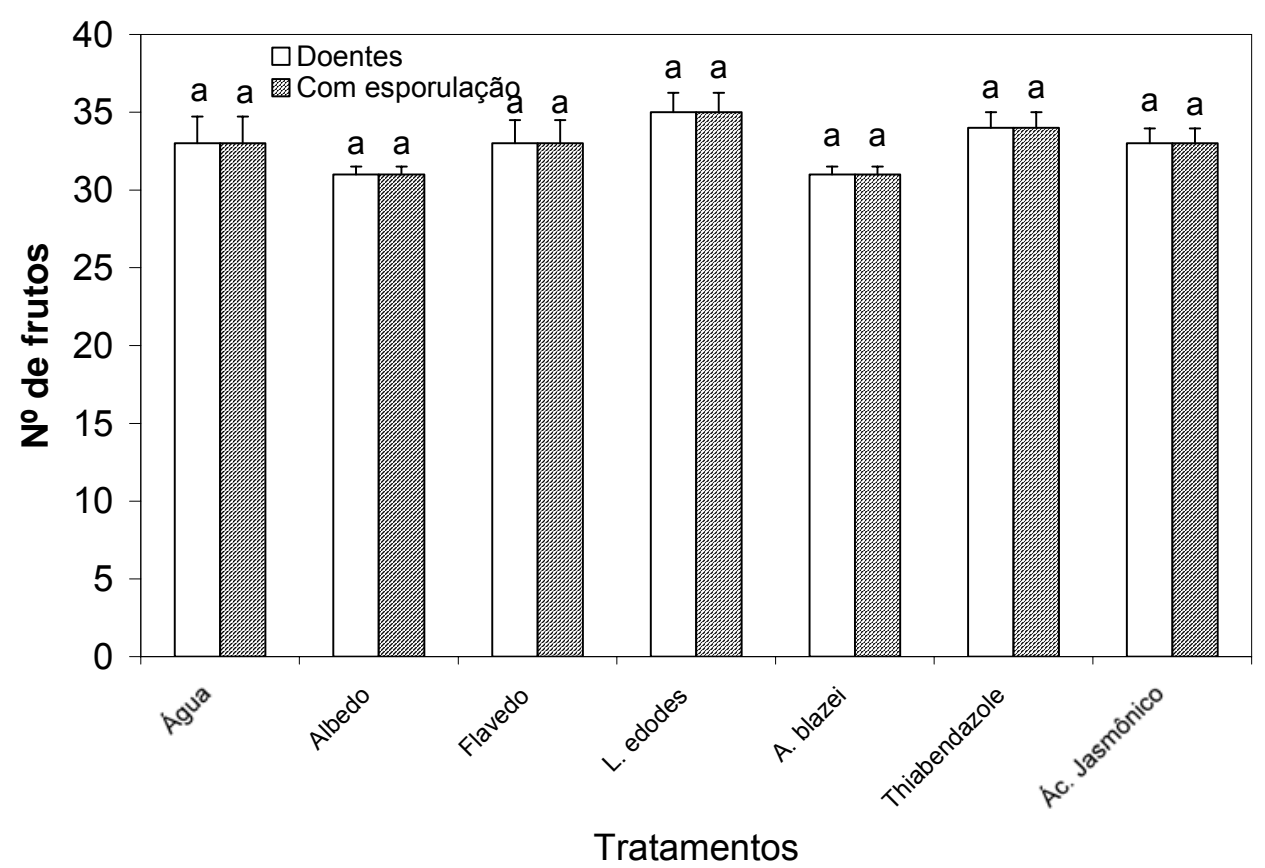

Figura 26 - Efeito indutor de resistência dos extratos aquosos do albedo de C. sinensis var. Valência, flavedo de C. aurantifolia var. Tahiti, L. edodes, A. blazei e do ácido jasmônico, aplicados em frutos de $C$. sinensis var. Valência no controle de $P$. digitatum. As barras representam a média \pm desvio padrão. Médias seguidas da mesma letra não diferem significativamente entre si (Tukey $\mathrm{P}=0,05)$

A casca dos citros é um habitat natural do $P$. digitatum, durante a fase patogênica do seu ciclo de vida. Em injúrias causadas nos frutos, durante as fases de colheita e pós-colheita, o esporo germina rapidamente, e inicia a infecção através dos ferimentos (KAVANAGH; WOOD, 1967). O interior do fruto só é colonizado, após o consumo dos compostos presentes no flavedo (KLOTZ, 1930). Estes compostos podem estimular, como também podem inibir o desenvolvimento do patógeno. O óleo retirado do flavedo dos citros, quando incorporado em meio de cultura ágar-água, estimulou a germinação de $P$. digitatum (FRENCH et al., 1978). Quando alguns compostos são verificados separadamente, o citral, nonanal, 6-metil-5-hepteno-2-ona, e citronelal estimularam a germinação de conídios de $P$. digitatum. Porém, afetaram a germinação de P. italicum. Contudo, muitos trabalhos demonstram que o óleo essencial e compostos voláteis, presentes no flavedo de frutos cítricos, interferem estimulando e inibindo o desenvolvimento do patógeno. 


\subsubsection{Influência dos agentes bióticos e abiótico sobre a antracnose em frutos de laranja Valência}

\subsubsection{1 - Efeito "protetor"}

No efeito protetor, os frutos foram tratados e logo após sofreram inoculação do patógeno. Todos os agentes utilizados apresentaram baixa inibição no aparecimento de frutos doentes e no tamanho de lesão por fruto causada pelo patógeno, com exceção do flavedo (Figura 27). O aparecimento da doença começou sete dias após a inoculação do fungo C. gloeosporioides (Figura 27a), ocorrendo o aumento do número de frutos doentes a cada avaliação em todos os tratamentos. É possível observar que o flavedo do limão "Tahiti" também manteve-se abaixo da testemunha (água) tanto no gráfico de frutos doentes (Figura 27a) quanto no gráfico de tamanho de lesão (Figura 27b). No entanto, os extratos não apresentaram diferença quanto ao número de frutos doentes e quanto ao tamanho médio de lesão por fruto, em relação a água. No último dia de avaliação, de acordo com o teste de Tukey a 5\% de probabilidade, o extrato do flavedo do "Tahiti" não apresentou diferença em relação aos demais tratamentos quando observados o número de frutos doentes, e quanto ao tamanho da lesão por fruto. Apesar de não diferir estatisticamente este resultado condiz com os resultados apresentados in vitro, sendo que o extrato etanólico de C. auratifolia var. Tahiti, quando colocado em contato com o fungo C. gloeosporioides inibiu o crescimento, a germinação e a formação de apressórios. 

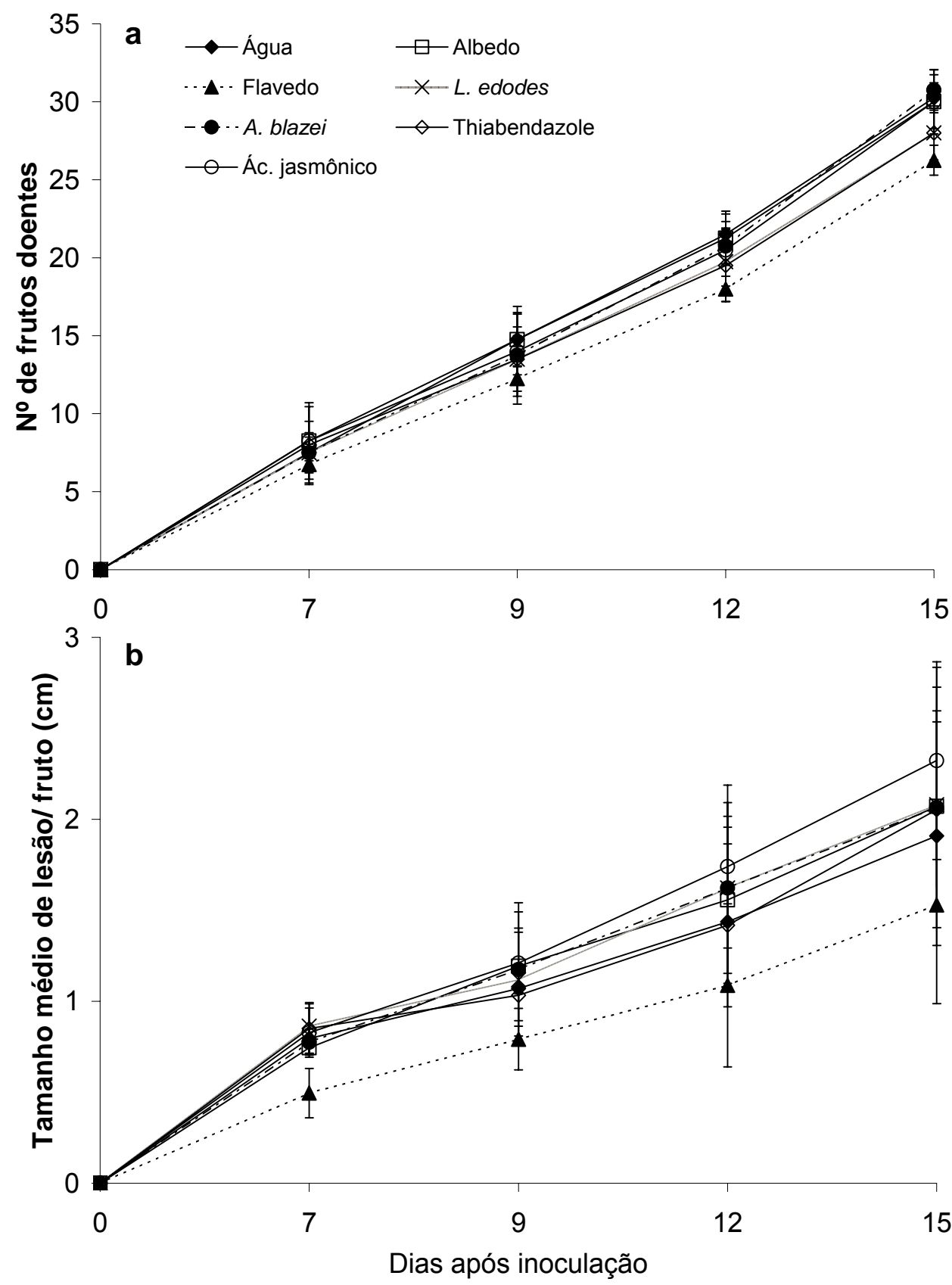

Figura 27 - Efeito protetor dos extratos aquosos do albedo de $C$. sinensis var. Valência, flavedo de C. aurantifolia var. Tahiti, L. edodes, A. blazei e do ácido jasmônico, aplicados em frutos de $C$. sinensis var. Valência no controle de $C$. gloeosporioides. As barras representam a média \pm desvio padrão 


\subsubsection{2 - Efeito "erradicante"}

No efeito erradicante, os frutos sofreram inoculação e logo em seguida foram tratados com os agentes. Todos os agentes utilizados apresentaram baixa inibição no aparecimento de frutos doentes e no tamanho de lesão por fruto causada pelo patógeno (Figura 28). O aparecimento dos sintomas começou sete dias após a inoculação do fungo C. gloeosporioides (Figura 28a), ocorrendo um aumento do número de frutos doentes e aumento no tamanho das lesões (Figura 28b), a cada dia de avaliação em todos os tratamentos. No último dia de avaliação, de acordo com o teste de Tukey a $5 \%$ de probabilidade, não se observam diferenças entre os tratamentos, tanto no número de frutos doentes, como no tamanho médio de lesão por fruto. 

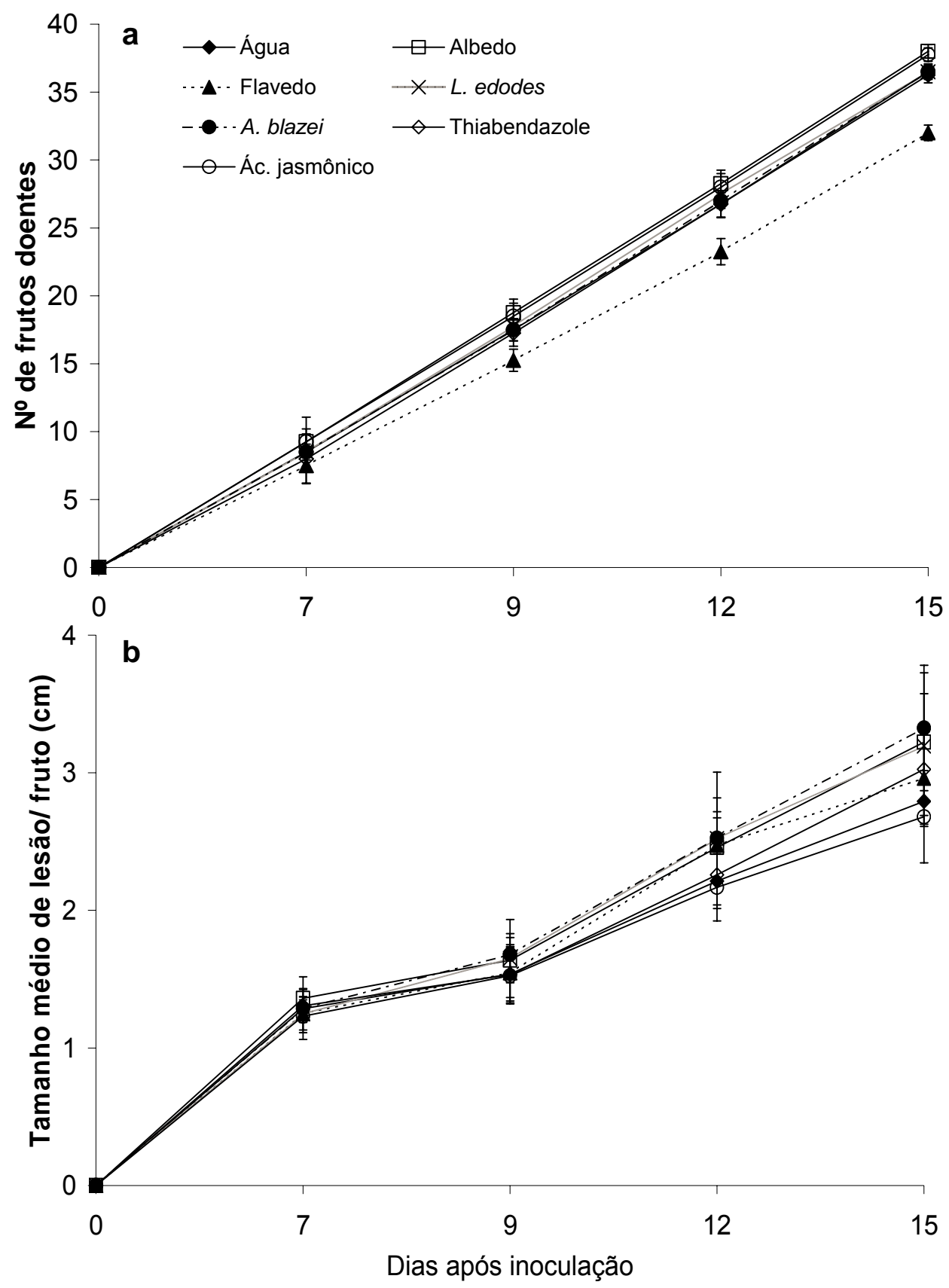

Figura 28 - Efeito erradicante dos extratos aquosos do albedo de $C$. sinensis var. Valência, flavedo de C. aurantifolia var. Tahiti, $L$. edodes, $A$. blazei e do ácido jasmônico, aplicados em frutos de $C$. sinensis var. Valência no controle de C. gloeosporioides. As barras representam a média \pm desvio padrão 


\subsubsection{3 - Efeito "curativo"}

No efeito curativo os frutos sofreram inoculação do patógeno e $24 \mathrm{~h}$ depois foram tratados pelos agentes. Todos os agentes utilizados apresentaram baixa inibição no aparecimento de frutos doentes e no tamanho de lesão por fruto causada pelo patógeno, com exceção do flavedo (Figura 29). O extrato do flavedo do limão "Tahiti" apresentou um número menor de frutos doentes (Figura 29a) e, ao contrário do efeito protetor, não apresentou diminuição no tamanho das lesões (Figura 29b). O aparecimento da doença começou sete dias após a inoculação do fungo $C$. gloeosporioides (Figura 29a), ocorrendo o aumento do número de frutos doentes e aumento no tamanho das lesões, a cada avaliação em todos os tratamentos. É possível observar que o flavedo do "Tahiti" manteve-se abaixo da linha da testemunha (água), somente no gráfico de frutos doentes. No último dia de avaliação, de acordo com o teste de Tukey a 5\% de probabilidade, o extrato do flavedo do "Tahiti" não apresentou diferença em relação aos demais tratamentos quando observados o número de frutos doentes, e quanto ao amanho de lesão por fruto. 

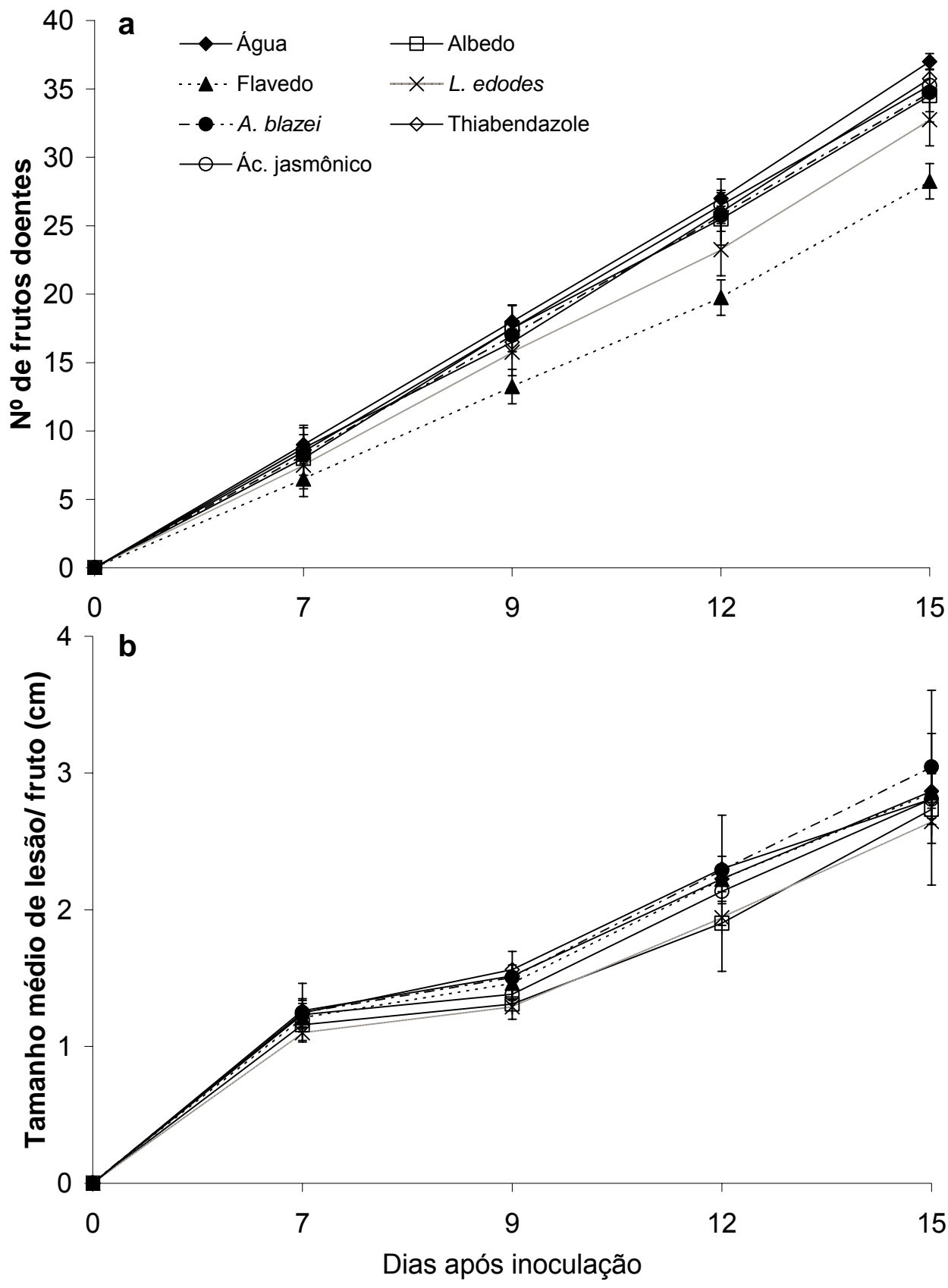

Figura 29 - Efeito curativo dos extratos aquosos do albedo de $C$. sinensis var. Valência, flavedo de $C$. aurantifolia var. Tahiti, $L$. edodes, A. blazei e do ácido jasmônico, aplicados em frutos de $C$. sinensis var. Valência no controle de C.gloeosporioides. As barras representam a média \pm desvio padrão 


\subsubsection{4 - Efeito "indutor de resistência"}

No efeito de indução, os frutos foram tratados e $48 \mathrm{~h}$ depois sofreram inoculação do patógeno (Figura 30). Todos os agentes utilizados apresentaram baixa inibição no aparecimento de frutos doentes e no tamanho de lesão por fruto causada pelo patógeno. O aparecimento dos sintomas começou sete dias após a inoculação do fungo C. gloeosporioides (Figura 30a), ocorrendo um aumento do número de frutos doentes e aumento no tamanho das lesões (Figura 30b), a cada dia de avaliação em todos os tratamentos. No último dia de avaliação, de acordo com o teste de Tukey a $5 \%$ de probabilidade, não se observa diferenças entre os tratamentos, tanto no número de frutos doentes, como no tamanho médio de lesão por fruto. 

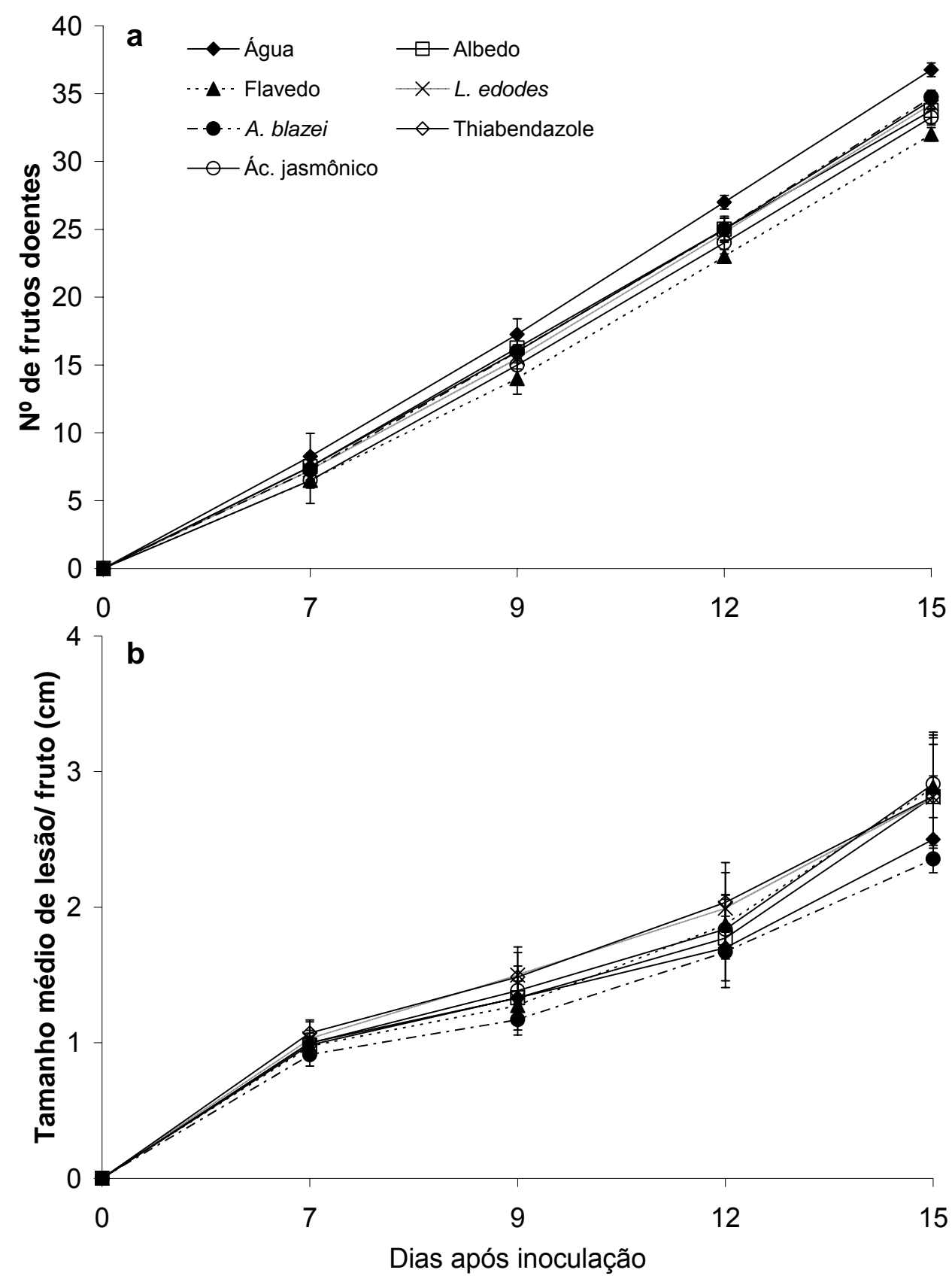

Figura 30 - Efeito indutor de resistência dos extratos aquosos do albedo de C. sinensis var. Valência, flavedo de C. aurantifolia var. Tahiti, L. edodes, A. blazei e do ácido jasmônico, aplicados em frutos de $C$. sinensis var. Valência no controle de $C$. gloeosporioides. As barras representam a média \pm desvio padrão 
Como foi observado em todos os tratamentos, nos diferentes tempos de aplicação e inoculação do patógeno, os frutos apresentaram alta suscetibilidade ao patógeno. Deve-se levar em consideração que o método de inoculação a partir de discos de micélio é drástico. Porém, houveram tentativas de inoculação a partir de um ferimento, onde foi depositada uma gota de suspensão de esporos. Várias concentrações de inóculo foram utilizadas, mas o aparecimento da doença, levava em média de 10 a 15 dias, e mesmo assim o número de frutos doentes era baixo, o que levou a utilização do método utilizando discos de micélio. 


\section{CONCLUSÕES}

Os extratos etanólicos do albedo de C. sinensis var. Valência e flavedo de $C$. aurantifolia var. Tahiti, apresentaram efeito antifúngico in vitro sobre G. citricarpa, e C. gloeosporioides, porém não ocorreu o mesmo sobre $P$. digitatum.

Os extratos aquosos do albedo de C. sinensis, flavedo de C. aurantifolia, Lentinula edodes e Agaricus blazei apresentam potencial como agentes de controle dos patógenos e de indução de resistência em frutos de laranja (C. sinensis var. Valência). 


\section{REFERÊNCIAS}

AGUILAR-VILDOSO, C.I.; RIBEIRO, J.G.B.; FEITCHTENBERGER, E.; GOES, A.; SPÓSITO, M.B. Manual técnico de procedimento da mancha preta dos citros. Brasília: MAPA/DAS/DDIV, 2002. 72 p.

ALI, M. K.; LEPOIVRE, P.; SEMAL, J. Fosetyl-Al treatment of Phytophthora citrophthora releases a higher scoparone elicitor activity from fosetyl-Al sensitive strain mutant than from an insensitive mutant. Fruits, Parc d'activites de Courtaboeuf, v. 46, p. 51-55, 1991.

ARRAS, G. Mode of action of an isolate of Candida famata in biological control of Penicillium digitatum in orange fruits. Postharvest Biology and Technology, Amsterdam, v. 8, p. 191-198, 1996.

ATHAYDE SOBRINHO, C.; FERREIRA, P. T. de; CAVALCANTI, L. S. Indutores Abióticos. In: CAVALCANTI. L. S; DI PIERO, R. M.; CIA, P.; PASCHOLATI, S. F.; VILELA DE RESENDE, M. L.; ROMEIRO, R. S. Indução de resistência em plantas a patógenos e insetos, Piracicaba: FEALQ, v. 13, p. 51-80, 2005.

AVERNA-SACCÁ, R. Pústulas pretas sobre laranjas doces produzidas pelo Phoma citricarpa. Revista de Agricultura, Piracicaba, v. 15, p. 668-674, 1940.

BAAYEN, R. P.; BONANTS, P. J. M.; VERKLEY, G.; CARROLL, G. C.; VAN der Aa, H. A.; WEERDT, M. de; VAN BROUWERSHAVEN, I.R.; SCHUTTE,G.C.; MACCHERONI Jr., W.; de BLANCO,C.G.; AZEVEDO,J.L. Nonpathogenic isolates of citrus black spot fungus, Guignardia citricarpa, identified as a cosmopolitan endophyte of woody plants, G. mangiferae (Phyllosticta capitalensis). Phytopathology, Lancaster, v. 92, p. 464477, 2002.

BALDASSARI, R. B. Patogenicidade, morfologia de colônias e diversidade de isolados de Guignardia citricarpa e G. margifera obtidos de Citrus spp. 2005. 66 p. Tese (Doutorado em Genética e Melhoramento de Plantas) - Faculdade de Ciências Agrárias e Veterinárias, Universidade Estadual Paulista “Júlio de Mesquita Filho", Jaboticabal. 2005.

BARROS, C. B.; YABIKU, H.Y.; PINTO, A.J.D. Óleos essenciais cítricos do Brasil. 2.ed. Campinas: Fundação Cargil, 1986. 43 p. 
BAUDOIN, A.B.A.M.; ECKERT, J.W. Factors influencing the susceptibility of lemons to infection by Geotrichum candidum. Phytopathology, Lancaster, v. 72, p. 1592-1597, 1982.

BENATO, E.A.; CIA, P.; SOUZA, N.L. Manejo de doenças de frutas pós-colheita. Revisão Anual de Patologia de Plantas, Passo Fundo, v. 9, p. 403-441, 2001.

BOSTOCK, R.M. Signal conflicts and synergies in induced resistance to multiple attackers. Physiological and Molecular Plant Pathology, London, v. 55, p. 99-109, 1999.

BRAGA, G.C.; EIRA, A.F.; CELSO, P.G.; COLAUTO, N.B. Manual do cultivo de Agaricus blazei "Cogumelo-do-sol". Botucatu: Fundação de Estudos e Pesquisas Agrícolas e Florestais, 1998. 44p.

BRODRICK, H. T.; RABIE, C. J. Light and temperature effects on symptom development and sporulation of Guignardia citricarpa Kiely, on Citrus sinensis (Linn.) Osbeck.

Phytophylactica, Pretoria, v. 2, p. 157-164, 1970.

BROWN, G.E. Factors affecting postharvest development of Colletotrichum gloeosporioides in citrus fruits. Phytopathology, Lancaster, v. 65, p. 404-409, 1975.

BROWN, G.E. Fruit handling and decay control techniques affecting quality. ACS Symposium Series, Washington, v. 143, p. 193-224, 1980.

BROWN, G.E. Resistance of decay fungi to benzimidazole fungicides used in Florida citrus packinghouses. Proceedings of the Florida State Horticulture Society, Winter Haven, v. 95, p. 239-242, 1982.

BROWN, G.E.; CHAMBERS, M. Evaluation of biological products for the control of postharvest diseases of Florida citrus. Proceedings of the Florida State Horticulture Society, Winter Haven, v. 109, p. 278-282, 1996.

BUS, V.G.; BONGERS, A.J.; RISSE, L.A. Occurrence of Penicillium italicum resistant to benomyl, thiabendazole, and imazalil on citrus fruit from different geographic origins.

Plant Disease, New York, v. 75, p. 1098-1100, 1991. 
CALAVAN, E. C. Black spot of citrus. California Citrograph, Los Angeles, v. 46, p. 2224, 1960.

CAMILI, E. C.; CIA, P.; BENATO, E. A. Indução de resistência contra doenças póscolheita. In: CAVALCANTI, L. S.; DI PIERO, R. M.; CIA, P.; PASCHOLATI, S. F.; VILELA DE RESENDE, M. L.; ROMEIRO, R. S. Indução de resistência em plantas a patógenos e insetos, Piracicaba: FEALQ, 2005. v. 13, p. 195-218.

CARDOSO FILHO, J.A. Efeito de extratos de albedo de laranja (Citrus sinensis) e dos indutores de resistência ácido salicílico, acibenzolar-S-metil e Saccharomyces cerevisae no controle de Phyllosticta citricarpa (teleomorfo: Guignardia citricarpa). 2003. 125 p. Tese (Doutorado em Microbiologia Agrícola) Escola Superior de Agricultura "Luiz de Queiroz", Universidade de São Paulo, Piracicaba, 2003.

CHITARRA, M. I. F.; CHITARRA, A.B. Pós-colheita de frutos e hortaliças: fisiologia e manejo. Lavras: ESA/FAEPE, 1990. 320p.

COHEN, E. Methods of degreening satsuma mandarin. Proceedings of the International Society of Citriculture, Berkeley: University of California, 1983. v. 2, p. $748-750$.

DANTAS, S.A.F.; OLIVEIRA, S.M.A.; MICHEREFF, S.J.; NASCIMENTO, L.C.;GURGEL, L.M.S.; PESSOA, W.R.L.S. Doenças fúngicas pós-colheita em mamões e laranjas comercializados na Central de Abastecimento do Recife. Fitopatologia Brasileira, Brasília, v. 28, p. 528-533, 2003.

DI PIERO, R.M.; PASCHOLATI, S.F. Atividade de quitinase induzida por Shiitake (Lentinula edodes) em folhas de pepino protegidas contra Colletotrichum lagenarium. Fitopatologia Brasileira, Brasília, v. 26, suplemento, p. 391, 2001. Resumo.

DI PIERO, R. M.; PASCHOLATI, S. F. Efeito dos cogumelos lentinula edodes e Agaricus blazei na interação entre plantas de tomate e Xanthomonas vesicatoria. Summa Phytopathologica, Botucatu, v. 30, p. 58-63, 2004a.

DI PIERO, R. M.; PASCHOLATI, S. Indução de resistencia em plantas de pepino contra Colletotrichum lagenarium pela aplicação de extratos de basidiocarpos de Lentinula edodes e Agaricus blazei. Summa Phytopathologica, Botucatu, v. 30, p. 243-250, 2004b. 
DÍAZ M.A.; VILA, R. El problema de la resistencia a los fungicidas: referencia a la situación en los almacenes españoles de comercialización de cítricos. Revista de Agroquímica y Tecnología de Alimentos, Valência, v. 28, p. 151-158, 1988.

DÍAZ M.A.; VILA, R. Imazalil resistant Penicillium isolates from Spanish citrus packinghouses. Microbiologie Aliments Nutrition, Chatenay-Malabry, v.7, p. 191-192, 1989.

DÍAZ M.A.; VILA, R.; HERNÁNDEZ, E. Detección de Penicillium italicum resistentes a OPPS, benomilo, TBZ y CGA-64251, procedentes de almacenes españoles de comercialización de frutos cítricos. Alimentaria, Madri, v. 184, p. 59-70, 1987a.

DÍAZ M.A.; VILA, R.; HERNÁNDEZ, E. Resistencia de Penicillium digitatum, aislados en centros espanõles de comercialización de cítricos, frente a los fungicidas OPPS, benomilo, TBZ y CGA-64251. Revista de Agroquímica y Tecnologia de Alimentos, Valência, v. 27, p. 439-445, 1987b.

DROBY, S.; VINOKUR, V.; WEISS, B.; COHEN, L.; DAUS, A.; GOLDSCHMIDT, E.E.; PORAT, R. Induction of resistance to Penicillium digitatum in grapefruit by the yeast biocontrol agent Candida oleophila. Phytopathology, Lancaster, v. 92, n. 4, p. 393-399, 2002.

ECKERT, J.W. Impact of fungicide resistance on citrus fruit decay control. In: GREEN, M.B.; LE BARON, H.M.; MOBERG, W.K. (Ed.). Managing Resistance to

Agrochemicals, American Society Symposium, Washington, v. 421, p. 286-302, 1990.

ECKERT, J.W. Post-harvest diseases of citrus fruits. Agriculture Outlook, Washington, v. 54, p. 225-232, 1993.

ECKERT, J.W.; BROWN, G.E. Postharvest citrus disease and their control. In: WARDOWSKI, W.F.; NAGY, S.; GRIERSON, W. (Ed.). Fresh Citrus Fruits. Westport, CT: AVI Publishing, 1986. p. 315-360.

ECKERT, J.W.; EAKS, I.L. Postharvest disorders and diseases of citrus fruits. In: REUTER, W.; CALAVAN, E.C.; CARMAN, G.E. (Ed.). The Citrus Industry. Berkeley, CA: University of California Press, 1989. v. 5. p. 179-260. 
EGUCHI, F.; WATANABE, Y.; KIKUKAWA, T.; YOSHIMOTO, H.; ABE, C.; HIGAKI, M. Renoprotetive effects of a hot water extract of Agaricus blazei fruiting bodies in experimental renal injury assessed by a DOCA-NaCl heminephrectomized rats. Journal of Tradicional Chinese Medicines, Pekín, v. 16, n. 1, p. 24-31, 1999.

EL-TOBSHY, Z.; SINCLAIR, J. B. Inhibition in vitro of Phomopsis citri by extracts from orange and by fungicides. Plant Disease Reporter, Washington, v. 48, p. 925-927, 1964.

FEITCHTENBERGER, E.; BASSANEZI, R.B.; SPÓSITO, M.B.; BELASQUE Junior., J. Doenças dos citros (Citrus spp). In: KIMATI, H.; AMORIM, L.; REZENDE, J.A.M.; BERGAMIN FILHO, A.; CAMARGO, L.E.A. (Ed.). Manual de Fipopatologia: Doenças das plantas cultivadas. São Paulo: Ceres, 2005. v. 2. p. 239-269.

FISCHER, I.H.; SPÓSITO, M.B.; LOURENÇO, S.A.; AMORIM, L. Eficiência dos fungicidas thiabendazole + imazalil, aplicados previamente ou em mistura à cera, no controle do bolor verde em citros. Brazilian Journal of Plant Physiology, Londrina, v. 16, p .22, 2004. Suplemento

FNP CONSULTORIA COMÉRCIO. Agrianual 2003: anuário estatístico da agricultura brasileira. São Paulo, p. 295-314: laranja, 2003.

FRENCH R.C.; LONG R.K.; LATTERELL F.M.; GRAHAM C.L.; SMOOOT J.J.; SHAW E. Effect of nonanal, citral and citrus oils on germination of conidia of Penicillium digitatum and Penicillium italicum. Phytopathology, Lancaster, v. 68, p. 877-822, 1978.

FUNDO DE DEFESA DA CITRUCULTURA. Manual técnico sobre Pinta Preta. Araraquara:Fundo Paulista de Defesa da Agricultura, 2000. 10 p. (Boletim Técnico, Edição especial).

FUNDO DE DEFESA DA CITRICULTURA. Nova avaliação. Revista Fundecitrus, Araraquara, n. 122, p. 8-9, 2004.

GÓES, A. de Controle da mancha-preta dos frutos cítricos. Laranja, Cordeirópolis, v. 9, p. 293-304, 1998. 
GÓES, A. de; FEICHTENBERGER, E. Ocorrência da mancha preta causada por Phyllosticta citricarpa (Mc.Apl.) Van der Aa. (Guignardia citricarpa Kiely) em pomares cítricos do estado de São Paulo. Fitopatologia Brasileira, Brasília, v. 18, p.138, 1993. Suplemento. /Apresentado ao 26., Congresso Brasileiro de Fitopatologia, Aracaju, 1993. Resumo.

GÓES, A. de; GRAÇA, J.; BARROS, J. M. de; PINHEIRO, J. E. Controle da pinta preta em frutos de tangerina "Rio"(Citrus deliciosa) ocasionada por Phyllosticta citricarpa. Fitopatologia Brasileira, Brasília, v. 13, p. 122. 1988 Suplemento. /Apresentado ao 21., Congresso De Fitopatologia, Salvador, 1988. Resumo.

GÓES, A. de; GRAÇA, J.; BARROS, J. C. S. M; PINHEIRO, J. E. Controle da pinta preta em frutos de tangerina Rio (Citrus deliciosa) ocasionada por Phyllosticta citricarpa (Guignardia citricarpa). Fitopatologia Brasileira, Brasília, v.15, p. 73-75, 1990.

GÓES, A. de; BARROS, J. C. S.M. de; GRAÇA, J.; CASTRO, N. G.; MARTINS, S. P. Determinação da época de produção de infecções latentes produzidas por Phyllosticta citricarpa em frutos de tangerina "Rio". Fitopatologia Brasileira, Brasília, v. 16, p. 34, 1991. Suplemento. /Apresentado ao 24., Congresso Brasileiro de Fitopatologia, Rio de Janeiro, 1991. Resumo.

HALLEWIN, G.; ARRAS, G.; DESSI, R.; DETTORI, A.; SCHIRRA, M; MICHALCZUK, L. Citrus green mould control in stored 'Star Ruby' grapefruit by the use of a bio-control yeast under curing conditions. Acta Horticulturae, The Hague, v. 1, n.485, p. 111-115, 1999.

HAMMERSCHMIDT, R. Induced resistance: how do induced plant stop pathogens? Physiological and Molecular Plant Pathology, London, v. 55, p. 77- 84, 1999.

HAMMERSCHMIDT, H.; DANN, E. K. Induced resistance to disease. In: RECHCIGL, N. A.; RECHCIGL, J. E. (Ed.). Environmentally safe approaches to crop disease control. Boca Raton: CRC Lewis Pub., cap.8, 1997. p. 177-199.

HOUCK, L.G. Problems of resistance to citrus fungicides. Proceedings of the International Society of Citriculture, Winter Haven, v. 1, p. 263-269, 1977.

KAVANAGH J.A.; WOOD R.K.S. The role of wounds in the infection of oranges by Penicillium digitatum Sacc. Annals of Applied Biology, Cambridge, v. 60, p. 375-383, 1967. 
KAWAGISHI, H.; KANAO, T.; INAGAKI, R.; MIZUNO, T.; SHIMURA, K.; ITO, H.; HAGIWARA, T.; NAKAMURA, T. Formolysis of a potent antitumor $(1 \rightarrow 6)-B$-D-glucanprotein complex from Agaricus blazei fruiting bodies and antitumor activity of resulting products. Carbohydrate Polymers, Barking, v. 12, n. 4, p. 393-403, 1990.

KIM, J.; YEHOSHUA, S. Histological detecction of phytoalexin scoparone from heattreated and UV-illuminated lemon fruits after inoculation with Penicillium digitatum. Plant Pathology Journal, Fasialabad, v. 17, n. 5, p. 271-275, 2001.

KLOTZ L.J. Some microscopical studies on Penicillium digitatum decay of citrus. Phytopathology, Lancaster, v. 20, p. 251-256, 1930.

KLOTZ, L. J. Color handbook of citrus disease. 4. ed. Berkeley: University of California, Division of Agricultural Sciences, 1973. 122 p.

KLOTZ, L. J. Fungal, bacteria and non-parasitic diseases and injuries originating in the seed, nursery, and orchard. In: REUTHER, W.; CALAVAN, E. C.; CARMAN, G. E. (Ed.). The citrus industry. Berkeley: University of California, 1978. 66 p.

KOTZÉ, J. M. Epidemiology and control of citrus black spot in South Africa. Plant Disease, New York, v. 65, p. 945-950, 1981.

KOTZÉ,J. M. History and epidemiology of Citrus Black Spot in South Africa.

Proceedings of International Society of Citriculture, Berkeley: University of California, v. 2, p. 1296-1299, 1996.

KOZLOWISKI, G., BUCHALA, A.; METRAUX, J.P. Methyl jasmonate protects Norway spruce (Picea abies (L.) Karst.) seedlings against Pythium ultimum Trow. Physiological and Molecular Plant Pathology, London, v. 55, p. 53-58, 1999.

LARANJEIRA, F.F.; AMORIM, L.; BERGAMIN FILHO, A.; AGUILAR-VILDOSO, C.I. Controle das doenças causadas por fungos e bactérias em citros. In: Zambolim, L; Ribeiro do Vale, F.X.; Monteiro, A.J.A.; Costa, H. Controle de doenças de plantas frutíferas, Viçosa, v. 2, p. 141-214, 2002.

LEITE, B.; NICHOLSON, R. L. Mycosporine-alaline: a self-inhibitor of germination from the conidial mucilage of Colletotrichum graminicola. Experimental Mycology, San Diego, v.16, p. 76-86, 1992. 
MAZZUZ, C.F. Calidad de frutos cítricos: manual para sugestion desde la recolección hasta la expedición. Barcelona: Ediciones de Horticultura, 1996. 317p.

MCONIE, K. C. The latent occurrence in citrus and others hosts of a Guignardia easiluy confused with $G$. citricarpa, the citrus black spot pathogens. Phytopathology, Lancaster, v. 54, p. 40-43, 1964.

MCONIE, K. C. Germination and infection of citrus by ascospores of Guignardia citricarpa in relation to control of black spot. Phytopathology, Lancaster, v. 57, p. 743746, 1967.

MENOLI, R.C.R.N.; MANTOVANI, M.S.; RIBEIRO, L.R.; SPEIT, G.; JORDÃO, B.Q. Antimutagenic effects of the mushroom Agaricus blazei extracts on V79 cells. Mutation Research, Amsterdam, v. 496, n. 1/2, p. 5-13, 2001.

MIZUNO, T. Kawariharatake, Agaricus blazei Murril: medicinal and dietary effects. Food Review International, New York, v. 11, n. 1, p. 167-172, 1995b.

MIZUNO, T.; HAGIWARA, T.; NAKAMURA, T.; ITO, H.; SHIMURA, K.; SUMIYA, T.; ASAKURA, A. Antitumor activity and some properties of water-soluble polysaccharides from "Himematsutake", the fruiting body of Agaricus blazei Murill. Agricultural and Biological Chemistry, Tokyo, v. 54, n. 11, p. 2889 -2896, 1990.

MIZUNO, M.; MINATO, K.; HITOSHI, I.; MITSUO, K.; HIROFUMI, T.; HIRONOBU, T. Anti-tumor polysaccharide from the mycelium of liquid-cultured Agaricus blazei. Biochemistry and Molecular Biology International, Tokyo, v.47, n.4, p. 707-714, 1999.

PACUMBABA, R.P; BEYL, C.A.; PACUMBABA, R.O. Shiitake mycelial leachate supresses growth of some bacterial species and symptoms of bacterial wilt of tomato and lima bean in vitro. Plant Disease, New York, v. 83, n. 1, p. 20-23, 1999.

PALOU, L.; USALL, J.; PONS, J.; CERDÀ, M.C.; VIÑAS, I. Micoflora en centrales citrícolas de Tarragona. Revista Investigación Agraria: Production Protección Vegetal, INIA, Epaña, v. 6, n. 3, p. 447-462, 2001.

PASCHOLATI, S. F.; LEITE, B. Mecanismos bioquímicos da resistência as doenças. Revisão Anual de Patologia de Plantas, Passo Fundo, v. 2, p.1-51,1994. 
PASCHOLATI, S. F.; LEITE, B. Hospedeiro: mecanismos de resistência. In: BERGAMIN FILHO, A.; KIMATI, H.; AMORIN, L. (Ed.) Manual de fitopatologia. 3. ed., Piracicaba:CERES, cap. 22, p. 417-422, 1995.

PASCHOLATI, S. F.; STANGARLIN, J. R.; PICCININ, E. Cogumelos: cultivo e comercialização (Shiitake e Cogumelo do Sol). Cuiabá: SEBRAE/MT, v. 17, 1998. 78 p. (Coleção Agroindústria).

PETRACEK, P.D.; MONTALVO, L. The degreening of 'Fallglo' tangerine. Journal of the American Society for Horticultural Science. Alexandria, v.122, n. 4, p. 547-552, 1997.

PICCININ, E. Potencial de preparações do cogumelo comestível shiitake (Lentinula edodes) no controle de fitopatógenos fúngicos, bacterianos e virais em sorgo, maracujá e fumo. 2000. 162p. Tese (Doutorado em Fitopatologia) - Escola Superior de Agricultura "Luiz de Queiroz", Universidade de São Paulo, Piracicaba, 2000.

PORAT, R.; LERS, A.; DORI, S.; COHEN, L; WEISS, B; DAUS, A; WILSON, C.L.; $\mathrm{DROBY}, \mathrm{S}$ Induction of chitinase and $ß-1,3-e n d o g l u c a n a s e$ proteins by UV irradiation and wounding in grapefruit peel tissue. Phytoparasitica, Bet Dagan, v.27, n. 3, p. 233238, 1999.

PORAT, R.; PAVONCELLO, D.; PERETZ, J.; WEISS, B; DAUS, A.; COHEN, L.; BEM YEHOSHUA, S.; FALLIK, E.; DROBY, S.; LURIE, S. Induction of resistance to Penicillium digitatum and chilling injury in 'Star Ruby' grapefruit by a short hot-water rinse and brushing treatment. Journal of Horticultural Science and Biotechnology, Ashford: Headley brothers, v. 75, n. 4, p. 428-432, 2000.

PORAT, R.; VINOKUR, V.; WEISS, B.; COHEN, L.; DAUS, A.; GOLDSCHMIDT, E.E.; DROBY, S. Induction of resistance to Penicillium digitatum in grapefruit by ßaminobutyric acid. European Journal of Plant Pathology, Dordrecht, v. 109, n. 9, p. 901-907, 2003.

PRATES, H. S.; NOGUEIRA, N. L. Controle químico da pinta preta (Phyllosticta citricarpa) em laranjeiras pêra. In: CONGRESSO PAULISTA DE FITOPATOLOGIA, 20, 1996. São Paulo. Programas e resumos. São Paulo: Grupo Paulista de Fitopatologia, 1996. p. 89. 
RITENOUR, M.A.; PELOSI, R.R.; BURTON, M.S.; STOVER, E.W.; DOU, H.T.; McCOLLUM, T.G. Assessing the efficacy of preharvest fungicide applications to control postharvest diseases of Florida citrus. HortTechnology, Alexandria, v. 14, n. 1, p. 5862, 2004.

ROBBS, C. F. A mancha preta dos frutos cítricos (Phyllosticta citricarpa) ameaça a citricultura paulista. Laranja, Cordeirópolis, v. 11, p. 75-86, 1990.

RODOV, S.; BEN-YEHOSHUA,D.; D'HALLEWIN,G.; CASTIA,T. Accumulation of phytoalexins scoparone and scopoletin in citrus fruits subjected to various postharvest treatments. Acta Horticulturae, The Hague, v. 1, n. 381, p. 517-523, 1994.

SASAKI, S. H. Protoplastização de Lentinula edodes e seu antagonismo sobre o vírus VSA e sobre fungos filamentosos. 1997. 69 p. Dissertação (Mestrado em Microbiologia) - Universidade Estadual de Londrina, Londrina, 1997.

SPÓSITO, M. B.; BASSANEZI, R. B. Problemas sanitários na pós-colheita para a exportação de frutas cítricas e métodos de controle. In: SIMPÓSIO DE CONTROLE DE DOENÇAS DE PLANTAS: PATOLOGIA PÓS-COLHEITA DE FRUTOS E HORTALIÇAS 2., 2002, Lavras. Anais: Lavras: UFLA/FAEPE, 2002. p. 79-83.

STICHER, L.; MAUCH-MANI, B.; MÉTRAUX, J.P. Systemic acquired resistance. Annual Review of Phytopathology, Palo Alto, v. 35, p. 235-270, 1997.

SUTTON, B. C.; WATERSON, J. M. Guignardia citricarpa. Kew: Commonwealth Mycological Institute, 1966. 2 p. (Descriptions of Pathogenic Fungi and Bacteria, 85).

TAKAKU, T.; KIMURA, Y.; OKUDA, H. Isolation of an antitumor compound from Agaricus blazei Murill and its mechanism of action. Journal of Nutrition, Bethesda, v. 131, n. 5, p. 1409-1413, 2001.

THALER, J.S. Jasmonic acid mediated interactions between plants, herbivores, parasitoids, and pathogens: a review of field experiments in tomato. In: AGRAWAL, A.A.; TUZUN, S.; BENT, E. (Ed.). Induced plant defenses against pathogens and herbivores. St.Paul: APS Press, 1999. p. 319-334.

TUSET J. J. Podredumbres de los frutos cítricos. Valencia: Conselleria d' Agricultura i Pesca. Generalitat Valenciana, 1987. 206 p. 
TUSET, J.J. Enfermidade durante la conservación. In: DURAN-VILA, N.; MORENO, P. Enfermedades de los cítricos. Madrid: Ediciones Mundi-Prensa, 2000. p. 99-114.

VAN LOON L.C.; BAKKER, P. A. H. M.; PIETERSE, C. M. J. Systemic resistance induced by rhizosphere bacteria. Annual Review of Phytopathology, Palo Alto, v. 36, p. $453-483,1998$.

WHITESIDE, J. O.; GARNSEY, S. M.; TIMMER, L. W. Compendium of citrus disease. 2 nd ed. St. Paul: APS Press, 1993. 87 p.

WILD, B.L., ECKERT, J.W. Synergy between a benzimidazole-sensitive isolate and benzimidazole-resistant isolates of Penicillium digitatum. Phytopathology, Lancaster, v. 72, p. 1329-1332, 1982. 